Historic, Archive Document

Do not assume content reflects current scientific knowledge, policies, or practices. 



\section{CATALOG №28}
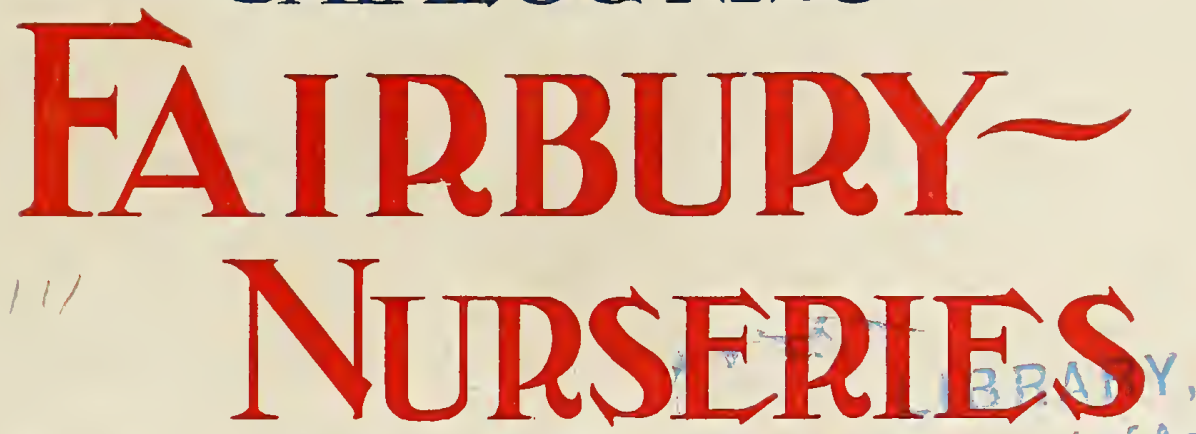

\section{FAIRBURY NEBRASKA SPRING AND FALI, 1911}

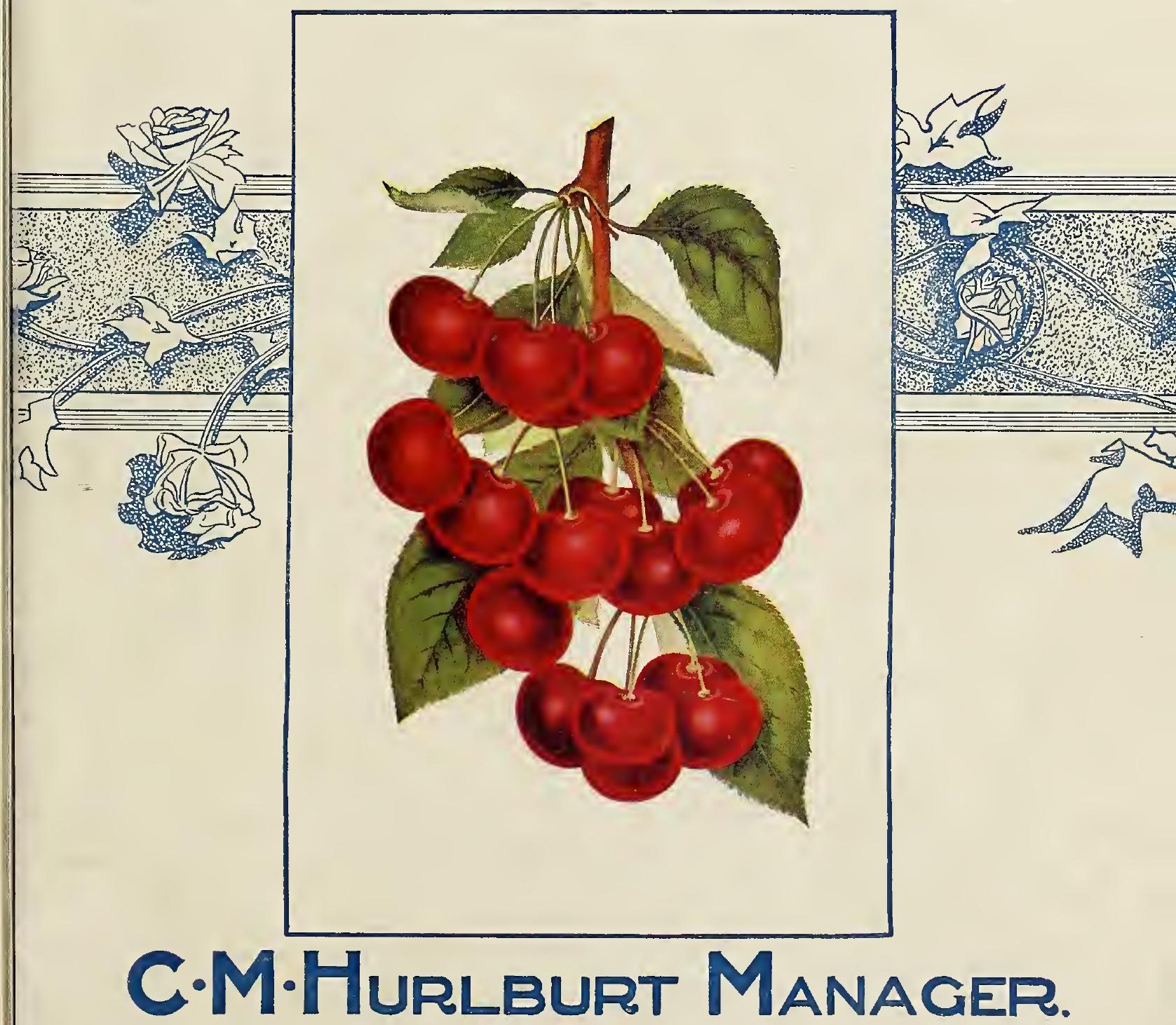


40 Concord grape vines, 1 year good stock for - - $\$ 1.00$ 10 cherry trees, assorted, 2 to 3 feet, budded trees for 1.00

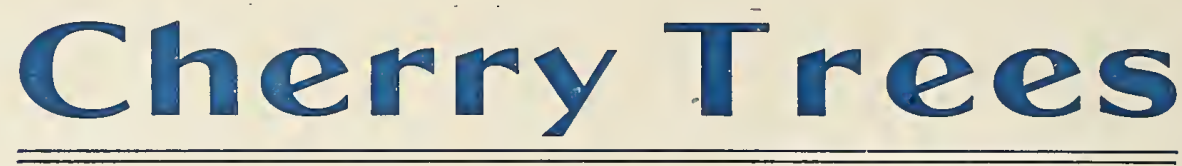

AT BARGAIN PRICES

E E have 50,000 Cherry Trees, Early Rich[5] mond, and Large Montmorency, on leased land that must be cleared by April 1st.

These are the BEST lot of Cherry we ever grew and we are offering them at the lowest prices at which we ever sold good trees.

4 year trees 5 to 7 feet, extra large, 50 cents each

3 year trees 5 to 6 feet, 30 c each, 100 for $\$ 25.00$

2 year trees 4 to 5 feet, 25c each, 100 for 20.00

2 year trees 3 to 4 feet, 20c each, 100 for 15.00

1 year trees 4 to 6 feet, 25c each, 100 for 18.00

1 year trees 4 to 5 feet, $20 \mathrm{c}$ each, 100 for 15.00

1 year trees 3 to 4 feet, $15 \mathrm{c}$ each, 100 for 12.00

1 year trees 2 to 3 feet, $12 \mathrm{c}$ each, 100 for 10.00

\section{We Pay Freight on \$10.00 Orders}

THE UNIVERSITY OF' NEBRASKA

DEP'T OF RNTOMOEOGY LINCOLN

I. WRENOT BRUNGR, PROFESSOR

FNTOMOLOGIST, HXPERTMENT STATION

AOTINe STATE FNTOMOLOeIST

MYRON H. SWENK, A DJUNCT ProftsSor

Asgistant State kintomologist

ENTOMOLOGIST'S CERTIFICATE OF NURSERY INSPECTION

THIS IS TO CERTIFY, that on August 24, 1910, I examined personally the stock and premises of the Fairbury Nurseries, C. M. Hurlburt, Manager, Fairbury, Nebr., and find no San Jose Scale nor indication that it has ever been present in the nursery or its vicinity and the stock is apparently in a healthy condition and free from all other dangerous insect pests.

This certificate is good for one year from date.

LAWRENCE BRUNER, State Entomologist. 


\section{FAIRBURY NURSERIES}

\section{M. Huriburt, Mgr.}

Fairbury, Neb.

All remittances by Postoffice Order, Express Mioney Order, Bank Draft and Regietered Letter at my risk. Do not send money in ordinary letters withoút registering it-it is not safe

\section{ALL POSTOFFICE MONEY ORDERS must be made out on Fairbury, Nebraska}

Your Name

Postoffice

County State

Name your Freight Station

How to be Sent-Freight, Express, Mail

Name your Railroad Company
Amt. Enc. P. O. Order $\$$

Amt. Enc. Exp. - $\$$

Amt. Enc. Draft . $\$ \ldots . .$.

Amt. Enc. Cash - \$....

Amt. Enc. Stamps -

Total - . $\$ \ldots \ldots$

Date

Very Important-No difference how often you have written us, always give your Full Address and write your Name Postoffice, County and State very plainly. By so doing you will save much trouble and avoid the possibility of delay and mistake in filling your orders.

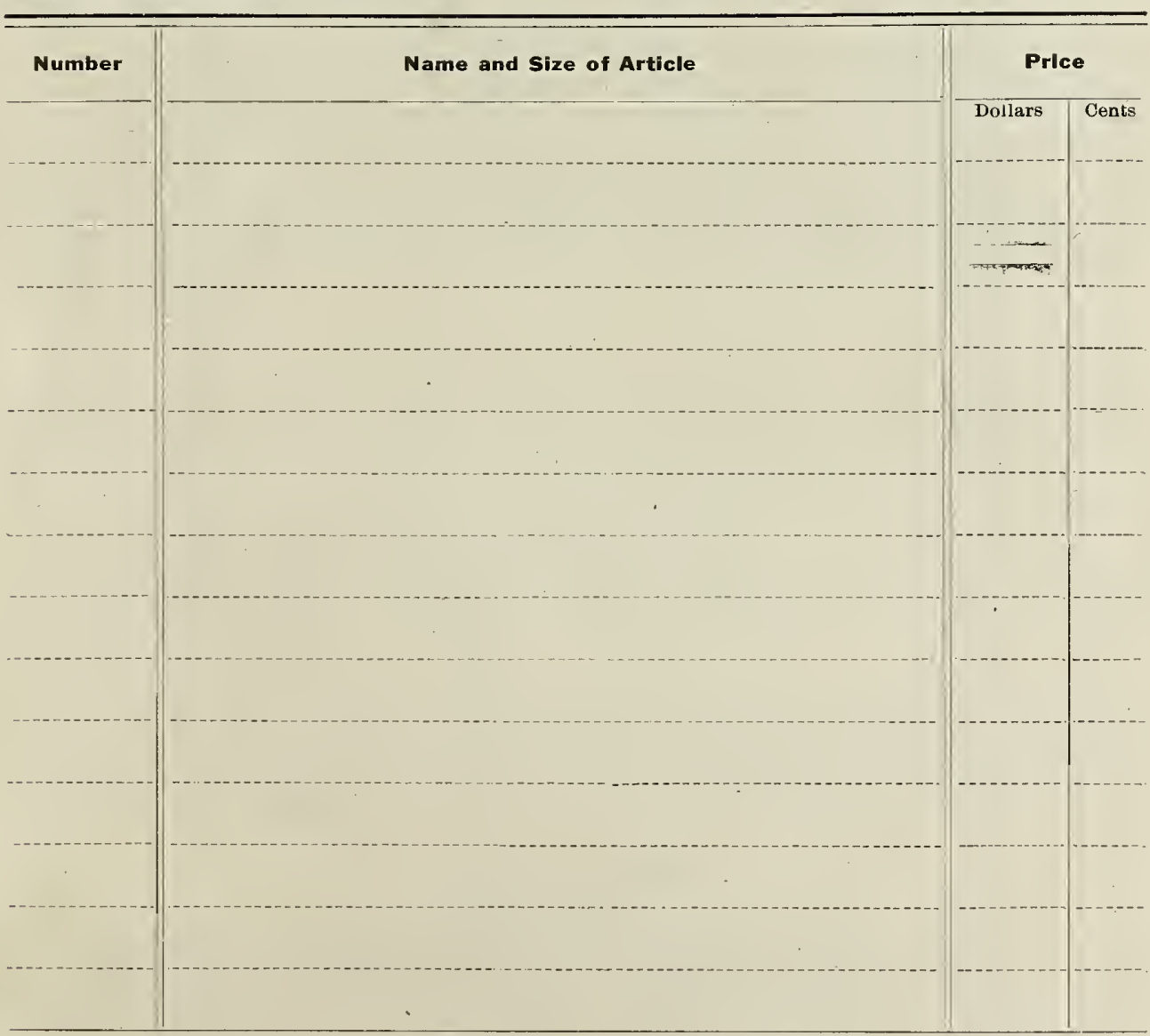


ORDER SHEET--Continued

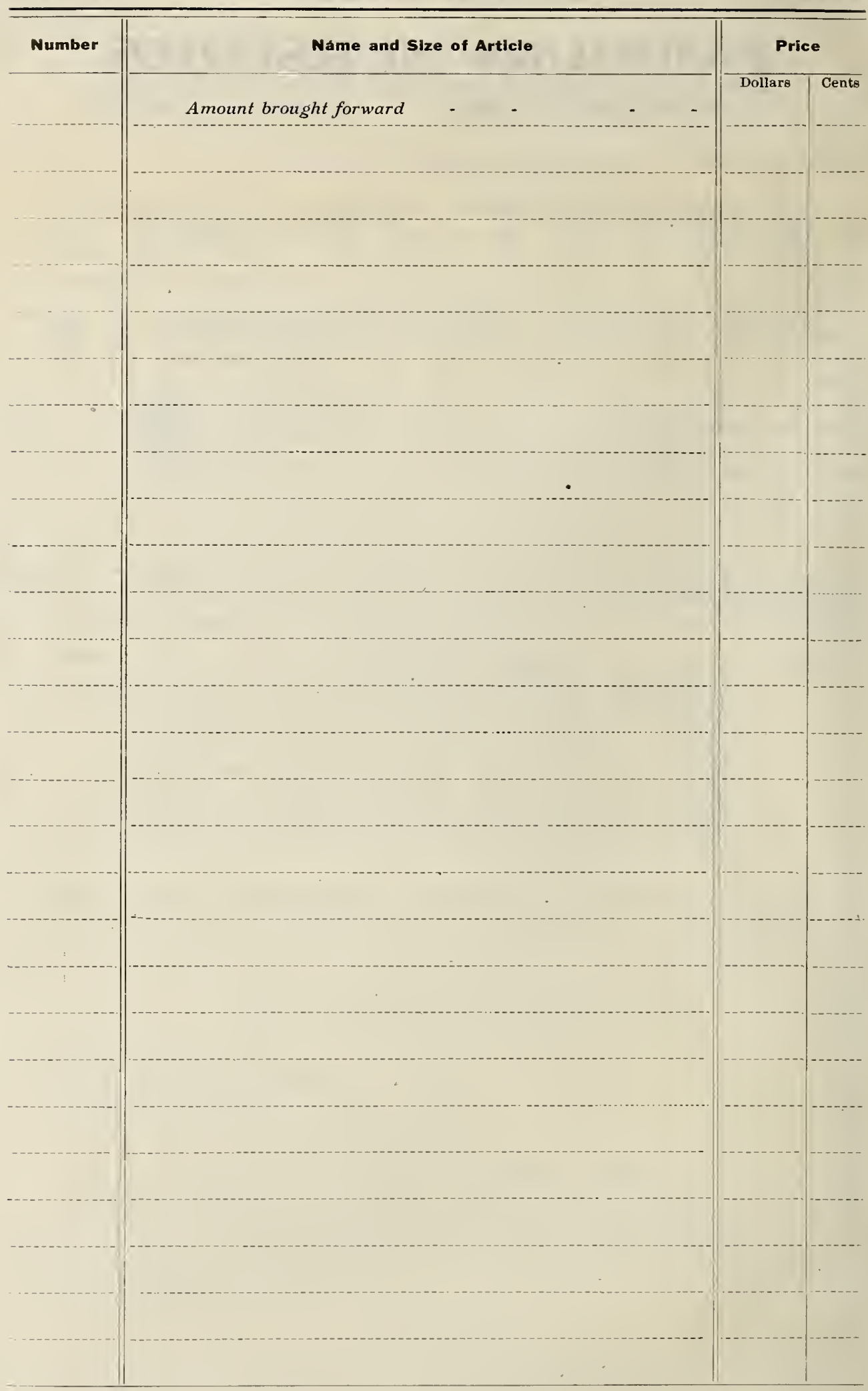




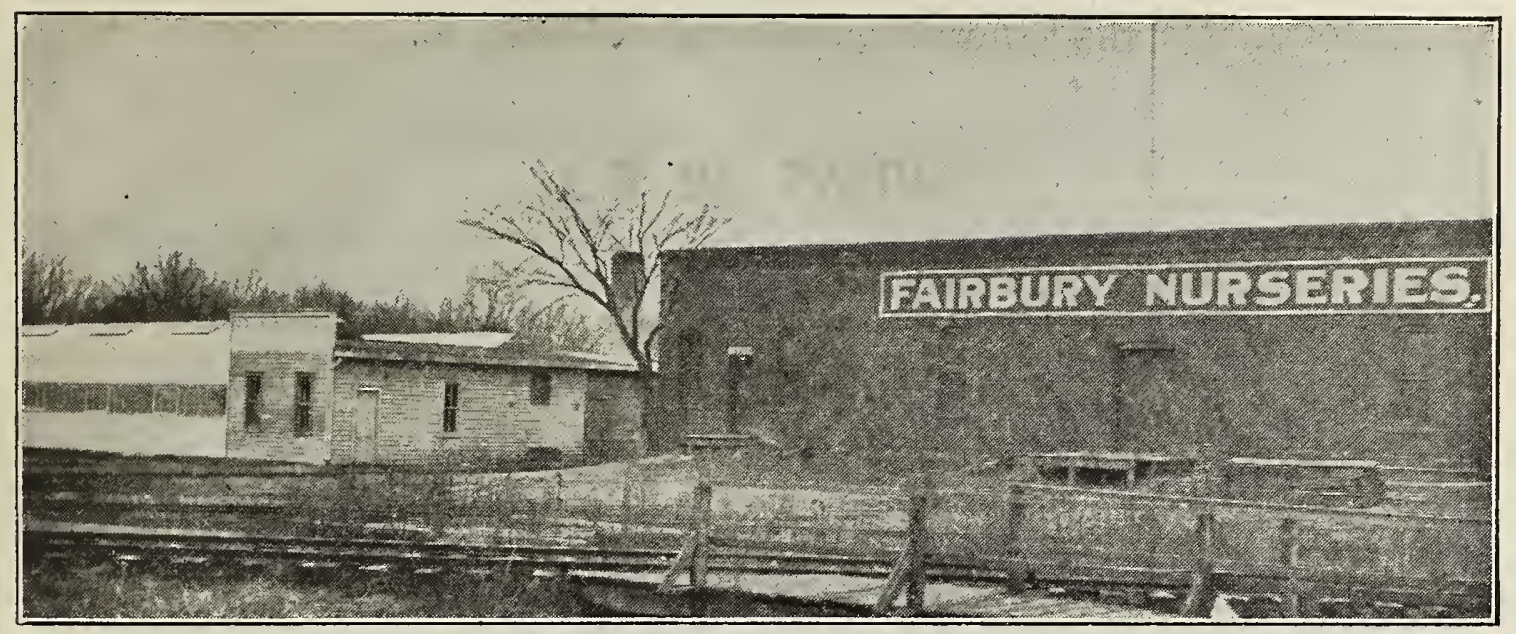

\section{PREFACE}

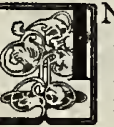

N preparing a catalogue of Fruits, Ornamental Trees, Flowering Shrubs, etc., it must be borne in mind that it is not an advertisement only to bring before the public what the nurseryman has in stock, but it is, indeed, more especially for the benefit of those desiring to use that which he produces. It is the Nurseryman's production that has made beautiful, pleasant and comfortable homes for the millions.

How deserted a home or farm would look without an orchard of well selected fruits; and can a city or village home be complete without its roses, shrubs, trees, etc.; and where space will admit, what is more beautiful in the outside adornment of a comfortable home than a combination of fruits and flowers? Is there anything more enticing than a tree or vine bending with its ripe, luscious fruit; and what is more attractive to the eye than a well arranged landscape covered with ornamental trees, shrubs and flowers? And since so much depends upon the Nurseryman for the production of the best varieties and true to name, he must by diligence, labor and experience be prepared to furnish that which will give satisfaction to the purchaser.

It is, therefore, the aim, in the preparation of this catalogue, to make the descriptions and time of ripening, etc., as accurate and intelligible as possible, and in so doing to lend assistance to those desiring to make selections, so that they may obtain varieties suited to their locality and also that a succession of ripening, from the earliest to the latest, among the fruits, and flowering among the ornamentals, may be obtained.

We herewith present your with our 1911 Catalogue and Price List and should be pleased to have your name appear upon on our order books this year.

We are still growing and selling choice nursery stock and have added to our plant three greenhouses from which we can supply you with a general assortment of plants such as are usually supplied by florists.

We are now in better position than ever to please our customers, having a larger and bettei stock on hand from which to select, and better facilities for handling and shipping the same, our sales are increasing each year as people are learning to know the good qualities of our trees, and that we are dealing honestly by them in sending them full value in stock for money received from them.

\section{DISCOUNTS}

We sell 5 trees at 10 rates, 50 trees at 100 rates, 500 trees at 1,000 rates.

On all cash orders, at prices in this catalogue, sent us before March 1st, 1910, we will allow 5 per cent dlscount. This offer is to induce you to order early. 


\section{WHAT WE DO}

We cultivate our trees in the most thorough manner and dig with the best improved tree digger, thus getting good length of roots.

We guarantee all trees, vines and plants to be in a good, healthy and growing condition when they leave our packing rooms.

In packing we use paper lined boxes or bales, using plenty of wet moss and straw, thus preventing stock from becoming dry in transit. We make no charge for bales or boxes.

While we take the best of care in filling orders with stock true to name, should a mistake occur we will be responsible only for the original cost of the stock.

We usually commence shipping in the fall, October 15 , and in the spring about March 10 . We can, however, ship a greater portion of our stock any time during the winter from our frost-proof cellars. By this plan we can accommodate our customers who live in the South.

On receipt of an order we notify the customer at once by card. If, after a reasonable length of time, you do not hear from us, write us again; sometimes letters go astray.

In filling orders we send varieties called for as far as possible. For those varieties we are out of we substitute others in their place equally as good, unless you write us not to substitute.

We ship over the St. Joseph \& Grand Island, the C., R. I. \& P. and the B. \& M. Railroads; over the United States, Wells-Fargo and Adams Express Companies.

\section{TERMS}

In ordering, always give age or size and price of stock wanted. Please be very particular in writing your name and address plainly.

Send cash with order, or good bank reference. If you wish stock sent C. O. D. by express, send one-fourth cash with order; we will then ship it, and you can pay balance due to your express agent on receipt of stock.

All remittances should be made payable to C. M. Hurlburt, Manager. Send by Postoffice or Express Money Order, Bank Draft, Check or Registered Letter. For amounts less than one dollar you may send one and two-cent stamps.

Our references are Goodrich Bros'. Bank, Harbine Bank, or R. G. Dunn \& Co.

\section{SPECIAL OFFERS}

On all orders that amount to $\$ 5$ or more will prepay the freight charges to any railroad station in Kansas or Nebraska.

On orders of $\$ 10$ or more we prepay freight charges to any station in the United States.

Sometimes our railroad agents here fail to collect enough freight charges from us on prepaid shipments. Should your agent require you to pay additional charges, send us the receipt he gave you, and we will return the money to you.

If you do not want enough trees for your own planting to secure prepaid freight, get some of your friends to club with you and we will tie and label each order separately and ship all together in one package and prepay the freight charges as provided above. 


\section{INSTRUCTIONS TO PLANTERS}

Never buy trees of a traveling tree agent. As a rule they are not trustworthy, and will charge from two to ten times what a tree is worth.

Buy direct from some reliable nursery, or from a local nursery agent that you know to be honest. By this plan you will save money and have a source of redress in case there is anything wrong with your order.

It is a good plan to send in your order early while the nursery's list of varieties is complete. Another thing, if you wait until late in the season, chances are that you will be so rushed with work that you will neglect to order at all, and thus lose a year's growth on your orchard.

As soon as trees are received the boxes or bundles should be unpacked and the roots of the trees soaked in a barrel or tank of water for twenty-four hours before planting; don't leave them in the water longer than this. If you are not ready to plant at once, they may be heeled in moist earth well packed around the roots.

In preparing ground, plow deep and pulverize the soil well before planting. Dig holes large enough so that roots of trees will have plenty of room. In planting fill holes two thirds full of loose soil, working it well among the roots as put in, then firm as solid as you can with the foot; fill remainder of hole with water; after it has soaked away fill up the hole with loose earth and do not firm it.

\section{Wintering Trees When Procured in the Fall}

Procuring trees in the autumn for early spring planting is recommended when the purchaser is not prepared to plant in the fall or prefers spring setting, or where the winters are too severe to set out young trees or plants in the fall, the greatest advantages derived in doing so are that when the roots have been cut or pruned, it will be found, upon taking them up in the spring, that a callous has been formed ready for the producing of new rootlets; and the trees, being planted without much exposure, as soon as the frost is out of the ground, will become thoroughly established the first season, and should make twice the growth of late planted trees, and the labor of planting is then done before the rush of spring planting sets in. To insure success, select a dry spot of ground where water will not stand during winter, and no grass or litter that will invite mice. Dig a trench from three to four feet wide, according to the amount of trees to be heeled in, and deep enough to admit one layer of roots and sloping enough to let the trees lie at an angle of about thirty degrees, throwing the earth on the back part of the trenches so as to make a more perfect slope on which to lay down the trees. Put in one layer of trees, placing the roots as close together as can conveniently be done, cover with well pulverized soil well up on the bodies and as carefully worked in about the roots as if they were being planted; then add another layer of trees, overlapping the first, and continue as at first until all are heeled in, throwing the ground well up around the trench, and where the winters are very severe it is advisable to cover the trees entirely up with earth. Evergreen boughs, coarse straw or corn fodder can be placed over the tops, but not thick enough to admit of a harbor for mice. The roots should be pruned before laying them down in the fall.

\section{Treatment of Trees, Etc., that Have been Frozen in the Packages or Received During Frosty Weather}

Put them unopened in a cellar or some other cool, protected place, free from frost, or cover them up heavily or entirely with earth until they are fully thawed out, when they can be unpacked and planted or placed in trenches until convenient to plant. Treated in this way they will not be injured by the freezing. 


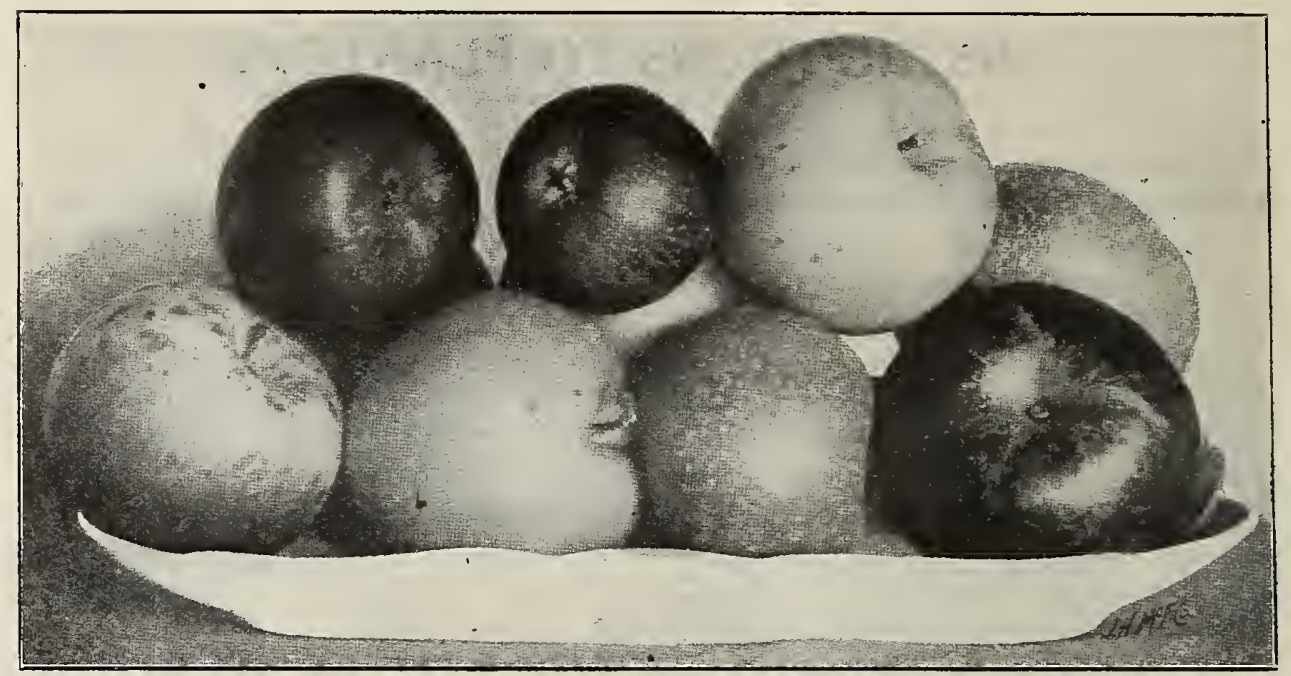

\section{APPLES}

The first fruit in importance is the apple. Its period of ripening, unlike that of other fruits, extends nearly or quite through the year. By making judicious selections of summer. autumn and winter sorts, a constant succession can easily be obtained of this indispensable fruit for family use.

If apples are planted at the rate of fifty trees per acre, rows of peach trees can be planted between the apples, which, growing more quickly than the apple trees, soon protect them from winds, and thus prove a great benefit to them. After eight or ten years of productiveness, as the space is needed for the apples, the peach trees may be removed, leaving the orchard better for the protection, and at the same time having yielded the planter a large return for his outlay and labor.

We would advise you in planting an apple orchard to selcct those varieties which have proven hardy and productive in our Western country. We give a brief description of varieties which we consider the best suited for Kansas and Nebraska.

The apple should be planted thirty feet apart each way. Plant trees about one inch deeper than they grew in the nursery row. In pruning keep them low headed; nothing here will ruin an apple orchard so quickly as high pruning, thus allowing the hot afternoon summer sun to scald the bark on the body of the tree.

In propagating the apple we use the piece root graft, the whole root graft and we also bud them. If you do not specify in your order which kind is preferred, we will send you the whole root trees.

$\begin{array}{rrr}\text { Per } 1 & \text { Per } 10 & \text { Per } 100 \\ \$ .30 & \$ 2.70 & \$ 25.00 \\ .25 & 2.20 & 20.00 \\ .20 & 1.70 & 15.00 \\ .15 & 1.20 & 10.00\end{array}$




\section{Summer Apples}

Carolina Red June-Tree hardy, upright, early bearer, shoots slender, foliage dark, color red, almost black in sun, fruit medium, form variable, suface smooth with minute dots.

Early Harvest-Medium to large, roundish, bright straw color, flesh white, tender, juicy, crisp, with rich sub-acid flavor; moderately vigorous and productive, one of the best. First of July.

Red Astrachan-Is of Russian origin and has proven itself a great favorite, especially in the North, hy its hardiness and good cooking quality. Tree vigorous, upright, foliage large, rich green; fruit medium to large, surface smooth, color striped crimson; season July. Recommended for general planting.

Dutchess of Oldenburg - Tree rather poor in nursery, but has proven one of the best for the North. Fruit large, surface smooth, waxen yellow ground covered with bright carmine stripes; sour, one of the very best for cooking; very productive. August.

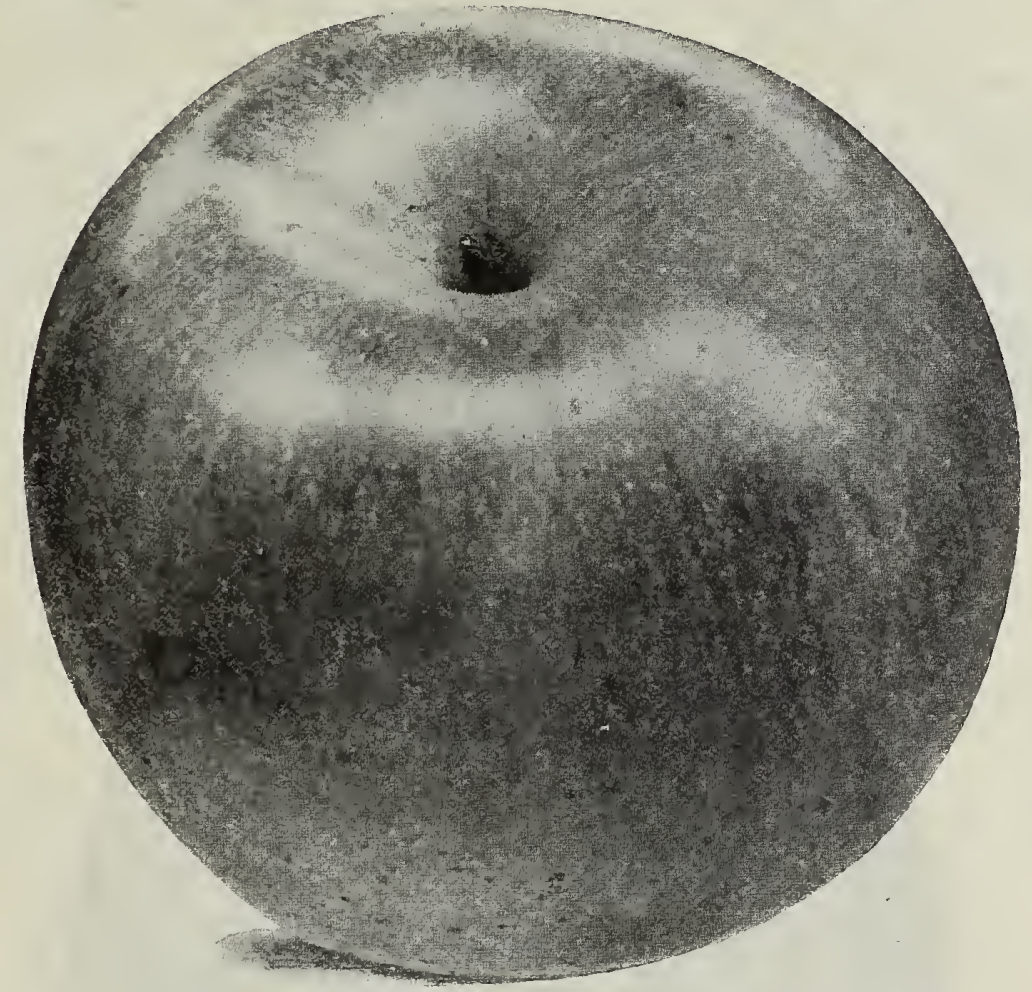

Fall Apples

Wealthy-An apple of fine appearance and quality, an early and profuse bearer; a good market apple of its season; tree hardy, its chief fault is killing itself by its early and excessive bearing. In size and beauty it equals Baldwin, and is a better dessert apple.

Wolf River-One of the largest apples grown, and very often used for show purposes when extra large apples are an attraction. Pleasant, sub-acid; tree hardy and vigorous. November and December.

Rambo-Tree upright, very thrifty and productive, beautiful foliage light green and perfectly hardy; fruit medium and liable to overbear, surface striped on green ground, numerous small dots, flesh greenish white, juicy flavor, sub-acid, aromatic, quality first for table. Season September and October.

Grimes' Golden-Tree upright and hardy, fruit full, color golden yellow when ripe, medium to large, quality sub-acid, mild and melting; valuable in any orchard.

Maiden's Blush-Rather large, oblate, smooth, regular, with a fine evenly shaded red cheek or blush on a clear pale yellow ground; flesh white, tender, sprightly, with a pleasant sub-acid flavor; bears large crops. August and September. 


\section{Winter Apples}

Ben Davis-(New York Pippin)-Fruit medium to large, round, skin yellowish, splashed and striped and almost covered with red, flesh white, tender, moderately juicy, sub-acid, an excellent variety, tree very hardy, a free grower, coming into bearing early and very productive. It bloums late in the spring, thereby often escaping late frosts; very popular in the West and Southwest. December and March.

Jonathan-Beautiful tree, good grower, fruit full medium, fair producer, color dark, shaded to almost black in sun, fruit drops in dry season. November and December, but can be kept until April.

Tallman Sweeting-Medium, pale yellow, firm, rich and very sweet; the most valuable preserving and baking apple, vigorous. October to December.

Northwestern Greening-Tree of Wisconsin origin, an extremely fine shaped, good growing tree in nursery and orchard. Fruit large and greenish yellow, good quality. It is claimed to keep well into June. Tree is quite hardy, and will probably succeed nearly as far north as the Wealthy. Very promising.

Mammoth Black Twig-Originated in Tennessee. Tree a fine upright, spreading grower, bears large crops and holds its fruits well. The fruit is fully one-tourth larger than the Winesap, which it resembles very much in color, flavor and keeping qualities. Vigorous. November to April.

Goneton, or Rawle's Janet-Old and favorably known variety; tree fairly vigorous, bears young, and if not allowed to overbear fruit, medium to small, quality not the best, but good keeper, blooms very late, thus never killed in bloom by late frosts.

Winesap-Too well known to require a description. Tree hardy almost wherever planted, early bearer and profitable; tree inclined to overbear, causing the fruit to be undersized; color red, sometimes almost black; flesh almost yellow, firm and crisp; one of the best. November to May'.

Missouri Pippin-Tree resembles a seedling, good grower, foliage dense, fruit early, very productive; fruit medium, surface smooth, shaded, mixed striped red; flavor sub-acid, very good: season December to March.

Other Varieties-Rome Beauty, Spy, Gano and Arkansas Black.

McIntosh Red-Large, roundish, skin mostly covered with bright red or crimson, almost purplish in the sun. Flesh white, very tender, juicy, mild sub-acid. Tree vigorous, extremely hardy and long lived. Good bearer.

\section{PRICES OF McINTOSH}

5 to 6 feet trees, $40 \mathrm{c}$ each 3 to 4 feet trees, 20c each

- 4 to 5 feet trees, 30c each 2 to 3 feet trees, 15c each

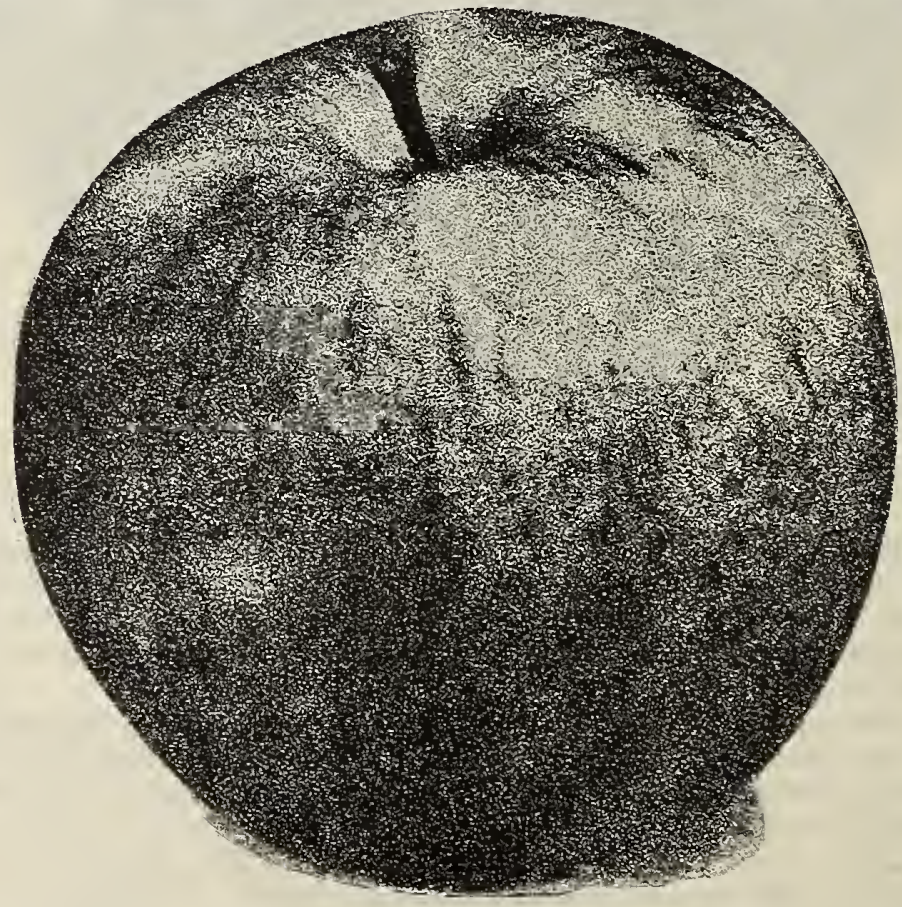

Winter Banane

Winter Banana-Here we have a novelty which, while new yet, has been proved to have a high degree of merit. It is a large, beautiful, golden yellow fruit, shaded and marbled 
with bright crimson. Flesh lemon-yellow, fine grained, with a rich, aromatic, sub-acid flavor. The name is no mistake, for as you eat the apple you are conscious of a delightful banana perfume. The fruit keeps well into spring, attaining during the last winter months the yellow of burnished gold, which, with its share of crimson, makes the Banana apple so attractive. The fruit, so far as we have observed it, grows very uniform, and every apple a good one-one as good as another. Fruit roundish, inclining to conical, stalk inch long, cavity moderate, and very showy in appearance. Ours is pedigreed stock, budded direct from bearing trees, and will be sure to bear young and give good satisfaction.

5 to 6 feet trees, $50 \mathrm{c}$ each

3 to 4 feet trees, $30 \mathrm{c}$ each

4 to 5 feet trees, $40 \mathrm{c}$ each

2 to 3 feet trees, $20 \mathrm{c}$ each

\section{Vaughn's Seedless Apple}

This remarkable apple tree was found by one of our local agents five years ago in Vermillion county, Ind., and we have procured the sole right to propagate and sell it.

On the following page we have two cuts of this apple-one showing the open calyx, the other showing little core and no seeds.

Now we do not claim that this is the largest apple known for there are many varieties just as large; nor is it the best flavored apple, for there are others just as good. But there are none so sure to bear a crop each year, and few that will keep as well; and,upon the strength of the above statement, we recommend it to our customers.

Why is it that an apple tree will bear a heavy crop of fruit one year, and then bear few or no apples for one to three years afterward? You have all noticed this. You will say that the tree in producing and maturing the heavy crop of fruit robbed itself of so much vitality that it was not able to produce fruit the second or third year; that it had to have time to recuperate, and grow new wood and fruit buds before it could produce again. This, we will admit, is the correct theory; but did you

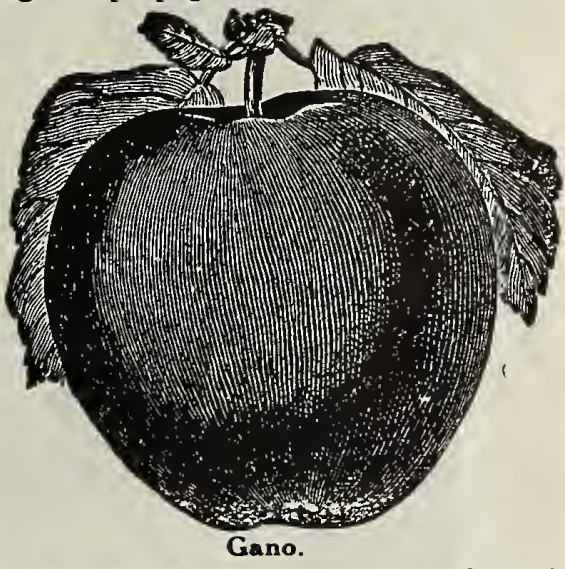
ever stop to consider what portion of the apple took the vitality from the tree? Is it the skin or flesh? No, for they are composed mostly of water, and the tree can produce them as easily as it can leaves, without loss of strength.

It is the seed of the apple and nothing else that robs the tree of its strength and causes it to produce only two years out of five. In Vaughn's Seedless Apple we have gotten rid of the element that produces barrenness, and by planting this variety we can raise apples every year.

Description-The fruit is about the size and shape of the Winesap; flesh firm and yellow, like the russet, with a flavor similar to the Rambo; nearly red in color, with small yellow dots, and will keep until May.

The tree has no bloom for late frosts to destroy, but the fruit is set in the closed bud. The fruit has a large open calyx which is an advantage over all other apples, for in spraying you can easily get the mixture with its poison into the calyx where it will be waiting for the pesky codling moth when it makes its appearance.

Trees will be shipped to our customers with a sealed tag attached to each tree, and no tree is genuine without this tag.

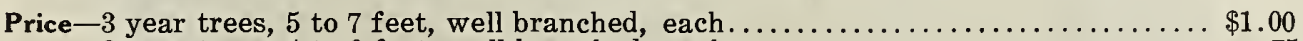

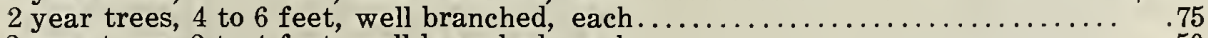

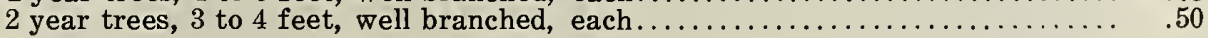

State of Indiana, Vermillion county, ss: Personally appeared before me, a Notary Public in and for said county, Martha E. James, who, being duly sworn, says that she has known the Vaughn Seedless Apple Tree for a period of 23 years, said tree having grown on my father's farm, and that it has grown fruit each year for the last 22 years. MARTHA E. JAMES.

Subscribed and sworn to this 25 th day of August, 1906.

My commission expires March 6, 1907.'

Jesse P. York, Notary Public.

State of Indiana, Vermillion county, sa: Personally appeared before me, a Notary Public in and for said county, this 25th day of August, 1906, August G. Vaughn, a citizen of said county and state, who, being duly sworn, says that the original Vaughn Seedless Apple Tree has been in bearing twenty-two consecutive years and no failures to affiant's knowledge.

Subscribed and sworn to this 25th day of August, 1906. Augustus G. VAUGHN.

My commission expires March 6, 1907.

Jesse P. York, Notary Public. 


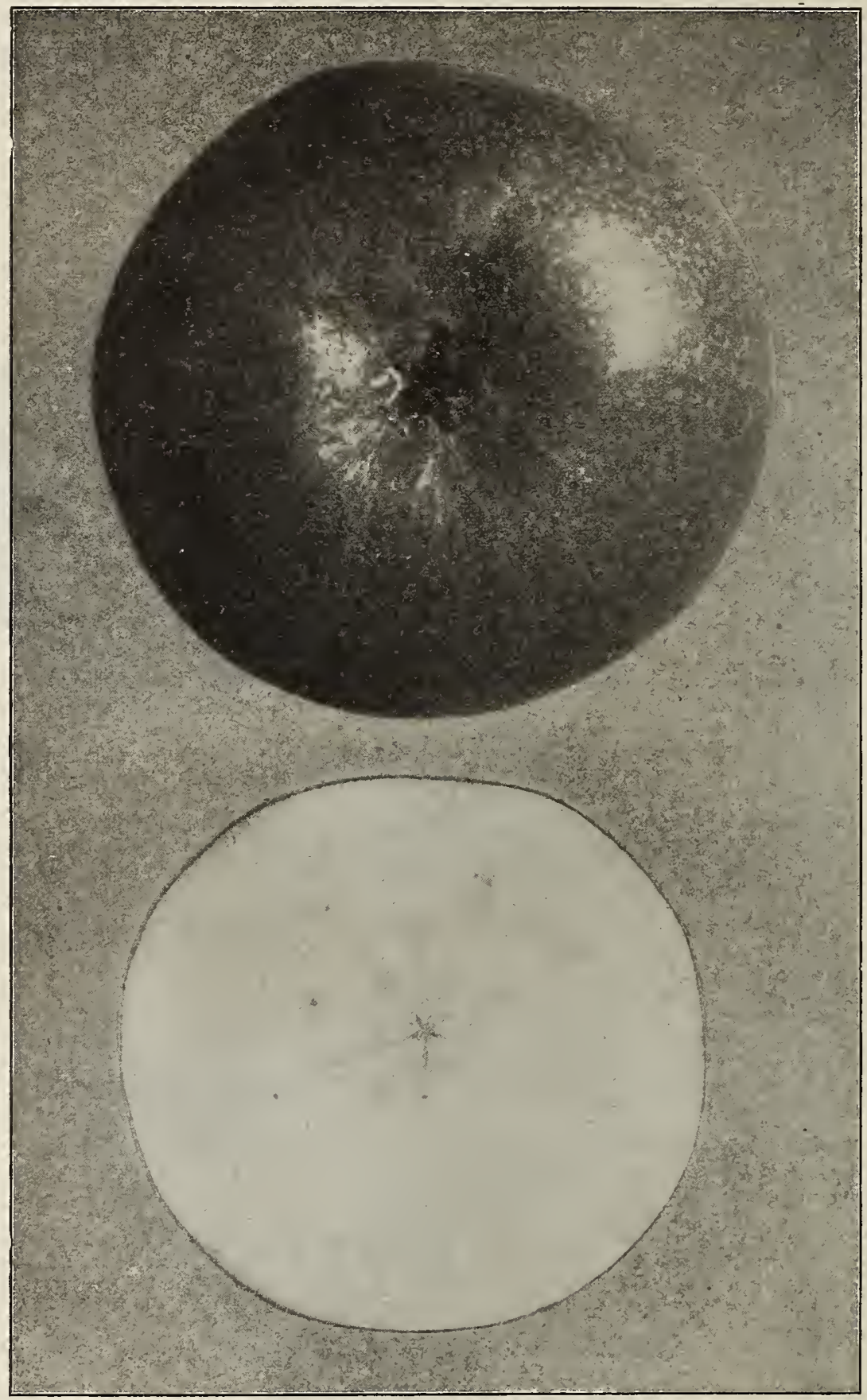

Vaughn's Seedless Apple 


\section{Bismarck}

In respect to its early fruiting habit, the most remarkable apple ever introduced; 1-year grafts frequently produce fruit, and 2-year trees seldom fail. Has fruited in many sections of the United States this season; we hear only words of commendation. Originated in New Zealand, has been tested in nearly every apple country and promises to succeed wherever apples can be grown, proving healthy, hardy, productive, and without a rival in its early fruiting quality. Tree of short, stocky growth, makes beautiful specimens grown in pots for decorative purposes. Fruit large, handsome yellow, sometimes shaded red cheek; flesh tender, pleasant sub-acid, good for dessert, superior for cooking; will keep well into winter.

Each

5 to 6 feet trees.................. $\$ .50$

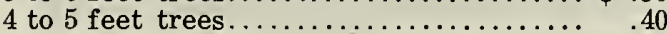

3 to 4 feet trees..................... . 30

2 to 3 feet trees $\ldots \ldots \ldots \ldots \ldots \ldots \ldots \ldots \ldots . .20$

\section{Crab Apples}

The improvements in the varieties of $\mathrm{Crab}$ Apples have kept pace with other kinds of fruit. A few years ago it was only thought fit for cider, jelly and preserves. But there are varieties now that command good prices in the market for dessert purposes; especially is this true of the Whitney. Besides being useful they are very ornamental when in bloom, and when burdened with their load of highly colored fruit.

Per 1 Per 10 Per 100 5 to 6 feet, 3 yrs., fine trees. . $\$ .30 \quad \$ 270 \$ 25$. 10 4 to 5 feet, 2 yrs., well branched $.25 \quad 2.20 \quad 20.00$ $\begin{array}{llll}3 \text { to } 4 \text { feet, } 2 \text { yrs., well branched } .20 & 1.70 & 15.00\end{array}$ 2 to $3 \mathrm{ft}$., 2 yrs., partly branch'd .15 $\quad 1.20 \quad 10.00$

Plant and prune them the same as apples. We give a description of varieties in the following that we consider among the best:

Hyslop-Tree hardy, upright round top, very prolific; fruit medium dark red, almost black in sun; good quality. Ripens in August.

Whitney Number Twenty-Tree extra fine, round headed, bears quite young, productive, fruit large, golden yellow with stripes of bright crimson, flavor sub-acid, quite free from the astringency of other crabs, excellent for vinegar. Season September.

Sylvan Sweet-Tree fine strong grower, very prolific, comes into bearing soon; fruit medium size and sweet. Fine for pickles.

Transcendent-Tree productive, fruit one and a-half to two inches in diameter; excellent for sauce and pies, and is also a good eating apple; skin yellow, striped with red; vigorous. August and September.

Martha-A seedling of Dutchess of Oldenburg, which originated in Minnesota. Earlier than the Transcendent; very ornamental, as well as a fine fruit; bears in profusion every year. September and October.

General Grant-Tree a vigorous and upright grower; fruit large; red to very dark red; flesh white, tender, mild sub-acid, excellent for dessert; free. October.

GoIden Beauty-Very large and handsome; fine amber or golden yellow color. 


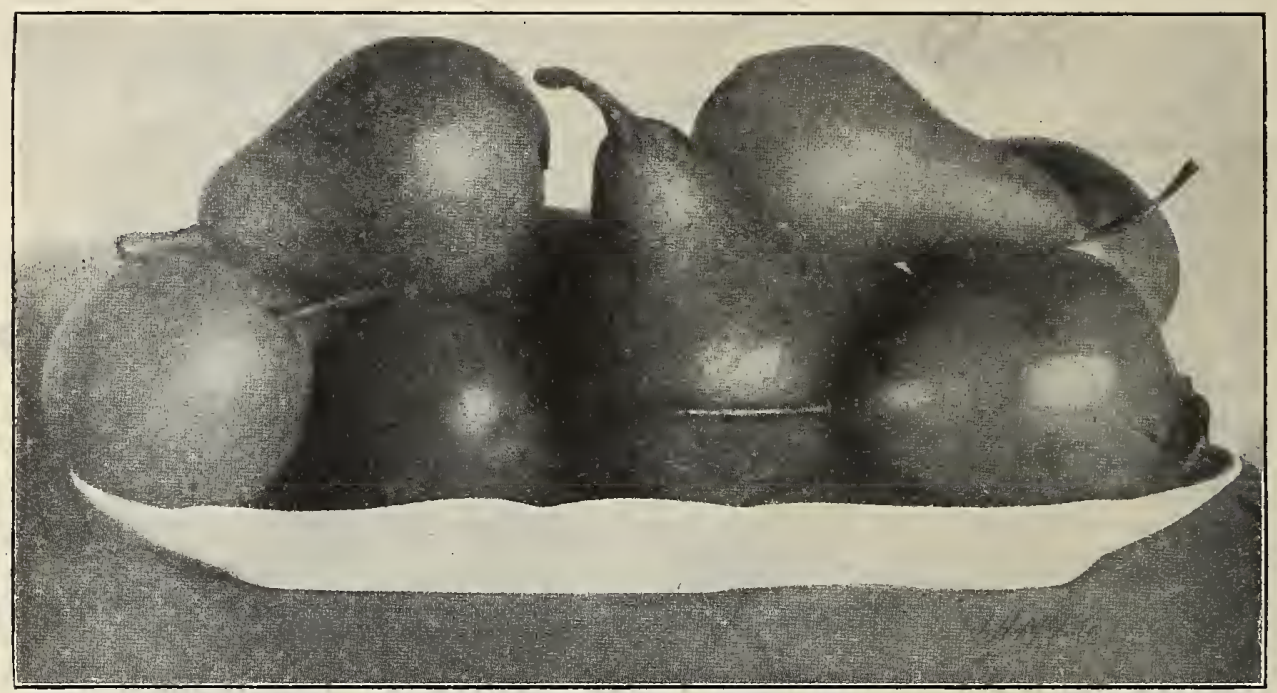

Dish of Clapp's Favorite Pears.

\section{Pears}

The Pear tree will grow on almost any good soil, but thrives best in a heavy clay or loam. Standards are best for permanent orchards, dwarfs for fruit gardens or small lots. Dwarfs must be planted deep enough to cover the junction of pear and quince two or three inches, and should have about half of the previous season's growth cut off each spring. Their side branches should not be removed higher than a foot from the ground. Given rich, well-tilled soil and pyramidal training, they are very productive and usually begin to bear the second season after planting. Our dwarf trees are budded on the best French quince stocks.

Two very important points in Pear culture are often neglected: the proper thinning and the gathering of the fruit When the trees are heavily laden the fruit should be thinned when about one-third grown, or it will be poor and the trees injured. Summer Pears should be gathered about ten days before they are ripe; autumn Pears at least a fortnight; winter varieties, if they will hang so long, may be left until the leaves begin to fall. If, on gently lifting the fruit, the stem separates readily from the twig, it is ripe for gathering. Winter Pears may be stored in any dry cellar and kept until early summer; other varieties may be ripened on shelves in any cool, airy place.

Dwarf Pears come into bearing two years after transplanting and standards not until the eighth year. $\quad$ Per 1 Per 10 Per 100 5 to 7 feet, Standard, 3 years, extra fine ................. \$ .32 $\$ 3.00 \quad \$ 28.00$

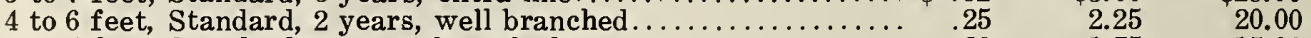

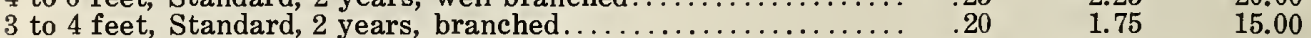

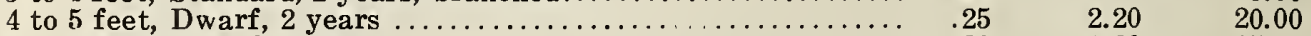

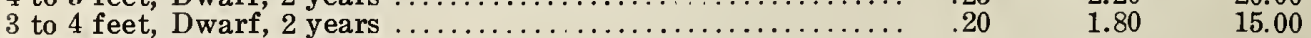

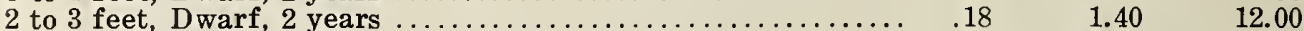

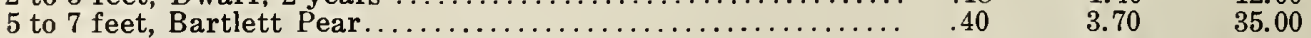

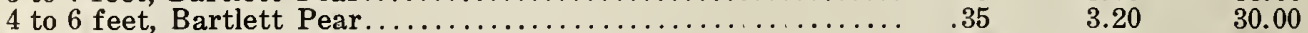

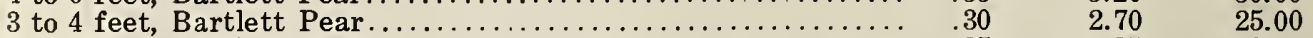

2 to 3 feet, Bartlett Pear............................ .25 $2.25 \quad 20.00$

Duchess d'Angouleme-Very large, dull greenish yellow streaked and spotted with russet, flesh white, buttery and very juicy, with rich and very excellent flavor, on the quince, to which stock this variety seems well adapted. It is always fine, the large and fine appearance of this fruit makes it a great favorite. September and October.

Seckel-Small, skin rich yellowish brown when ripe, with a dull brownish red cheek, flesh very fine grained, sweet, is exceedingly juicy, melting, buttery, the richest, highest flavored pear known. August and September.

Flemish Beauty-Is large, beautiful, juicy, melting, rich and fine, good bearer, is hardy everywhere. August and September.

Lawrence-Is rather laroe, yellow, covered with brown dots, flesh whitish, slightly granular, somewhat buttery, with a rich aromatic flavor; unsurpassed among the early winter pears, succeeds well on the quince, ripens with little care, should be in every orchard; tree healthy, hardy and productive. November and December. 


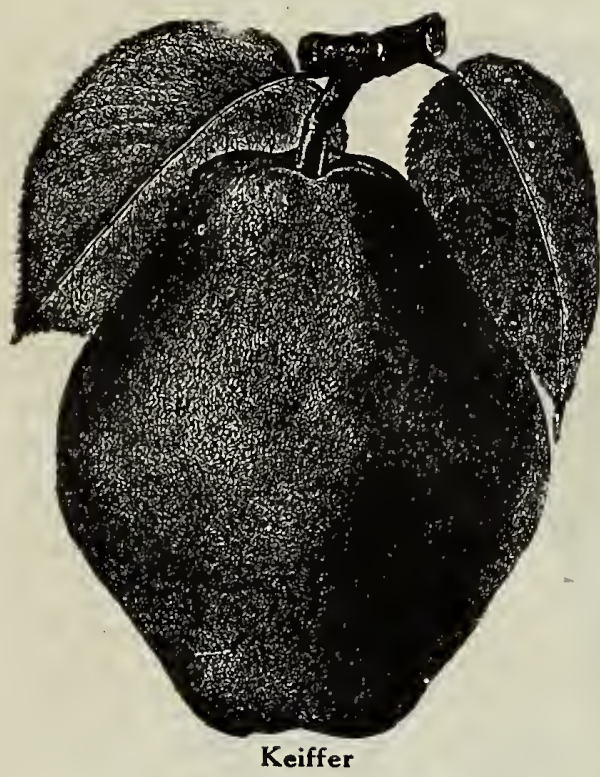

Bartlett-Large size with often a beautiful blush to the sun; buttery, very juicy and highly flavored; bears early and abundantly; very popular. August.

Clapp's Favorite-Very large, yellowish green to full yellow when ripe, marbled with dull red in the sun and covered with small russet specks, vinous, melting and rich; season, July.

Kieffer's Hybrid-The pear was raised from seed from Chinese Sand Pear, accidentally crossed with the Bartlett or some other kind grown near it. Tree has large dark, green, glossy leaves, and is of itself very ornamental; is an early and very prolific bearer. The fruit is of good quality, wonderfully showy and is valuable for the table and market. It never rots at the core, and is as nearly blight proof as is possible for any pear to be. September and October.

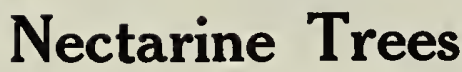

The Nectarine has a smooth skin like the plum and requires the same treatment for curculio. It is like the peach in other ways and requires the same culture. The following varieties are best:

Boston-The largest and most beautiful variety known. Deep yellow, mottled and shaded with red, flesh sweet, with a peculiarly pleasant flavor, free stone. Tree hardy and productive. September.

Downton-Large pale green, with violet red cheek, flesh rich and delightful, free from stone. August.

3 to 4 foot trees

Per 1 Per 10 $\$ .25 \quad \$ 2.00$

\section{Budded Peaches}

The peach tree requires a moderately rich, well drained soil, and in order to preserve the continued healthy growth of the tree and thus cause it to produce well matured fruit its branches should be headed in each year.

Peach trees when planted alone should be set twenty feet apart, or they may be planted between apple trees. Plant them deep enough so that the crook in the tree where they were budded is covered over with earth.

In Nebraska we cannot expect a full crop of peaches each year, owing to our cold winters, which kill the bloom buds; but if you can only get a full crop once in three years they will pay you better than any other fruit crop that can be raised in Nebraska, cherries and strawberries excepted.

Below we give a short description of those varieties which we consider among the best, the greatest number of which we have fruited in our own grounds. Per 1 Per 10 Per 100

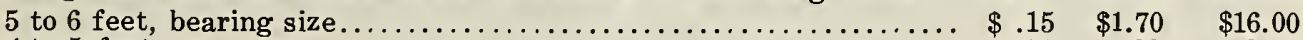

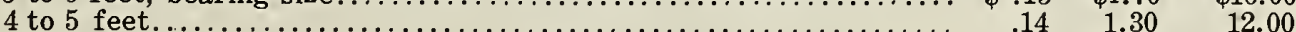

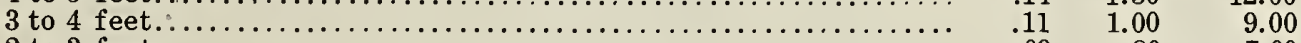

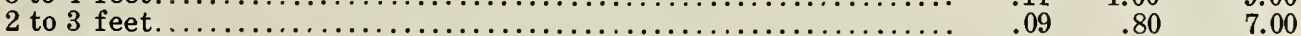

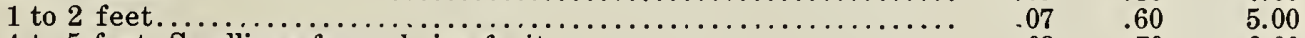

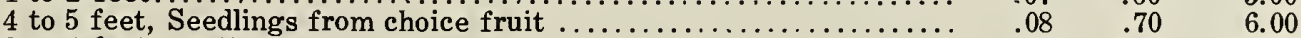

3 to 4 feet, " " " "

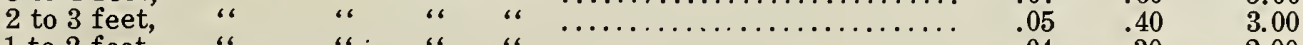

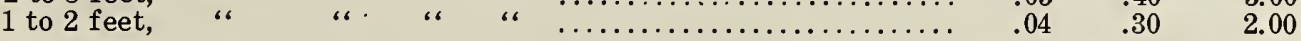

Champion-Many specimens have measured 10 inches in circumference. The flavor is delicious, rich, sweet and juicy; surpasses all other early varieties; skin creamy white with red cheek, strikingly handsome. It is hardy, productive, the largest size, highest flavor and best shipper of the early peaches. Ripens in early August. 


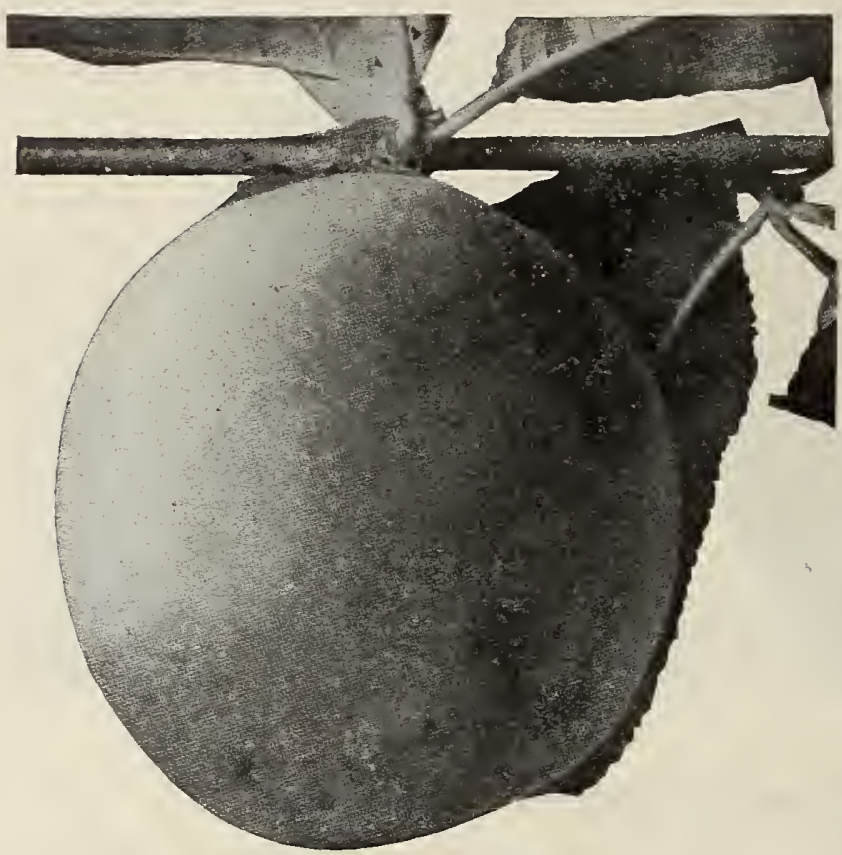

Champion Peach.

Elberta-A Geòrgia cross between Crawford and Chinese Cling; very large, well colored. All things considered, the finest yellow freestone in cultivation; no one can go amiss by planting it; fruit perfectly free from rot, and one of the most successful shipping varieties. August 20.

Chinese Cling-Most popular Southern peach, immense size, oblong, creamy skin with faint blush of red. August.

Bokhara Numbe ThreeRaised from seed secured from Bokhara, Asia, a number of seedlings being produced that proved 30 per cent hardier than the old strain of peach trees. One of the seedlings, Number Three, proved decidedly the best; has been fruited in Iowa several years, and found one of the hardiest and best peaches known here.

Blood Cling - Large size, dark claret, with veins downy; flesh deep red, very juicy, fine flavor; tree an irregular grower. October.

Alexander Early - Large size, well grown specimens measuring eight inches in circumference, handsome and regular in form with deep maroon shade, covered with the richest tint of crimson, rich and good in quality, with a vinous flavor; adheres to the stone; should remain on the tree until fully ripe. Late in June.

Crawford's Early-This beautiful yellow peach is highly esteemed for market purposes. Fruit very large, oblong; skin yellow with fine red cheeks; flesh yellow, juicy, sweet, excellent, productive, free. Last of July.

Crawford's Late-Fruit of the largest size; skin yellow with dull red cheek; flesh yellow; productive, one of the best. Last of August and September.

Mountain Rose-Large, red. flesh white, rich, juicy, excellent; one of the best early peaches, ripening with Troth's Early, and much larger and finer than that variety; should be in every collection. July.

Crosby-Medium size; bright orange yellow, streaked with carmine. On account of its beautiful color and fine quality it commands a ready sale in competition with the best standard market sorts. Claimed to be the hardiest of all peaches. Good for home and market; free. September 10.

Greensboro-Origin, North Carolina. Ripens a week later than Alexander, but much larger. $R$ sund, sometimes elongated; flesh white, very juicy, of good quality; skin white, with red cheek, highly colored in the sun. A favorite, and profitable early market sort.

Triumph-Earliest yellow flesh peach, with good eating and shipping qualities. Ripens with Alexander, blooms late, sure and abundant bearer; strong, vigorous grower. Fruit good size, yellow with red and crimson cheek. Fruit growers have given the strongest testimonials to its value.

Salway-Late peach, fruit large, roundish, yellow, with rich marbled brownish-red cheek; flesh yellow, firm, juicy, rich, sugary. Showy market peach; is very promising; finest in the world for canning. October. Free.

Globe-An improvement on Crawford's Late. Fruit large, globular, of a rich golden yellow with red blush, flesh yellow, juicy. August.

Hale's Early-Fruit medium size; skin white, delicately marbled with bright and dark red on sunny side; flesh very melting, juicy and highly flavored. July 10 to 20 .

Stump the World-Very large, roundish, skin white, juicy and good; free. End of August.

Early Rivers-Large, light straw color, with delicate pink cheek; flesh juicy and melting with very rich flavor. First of July. 


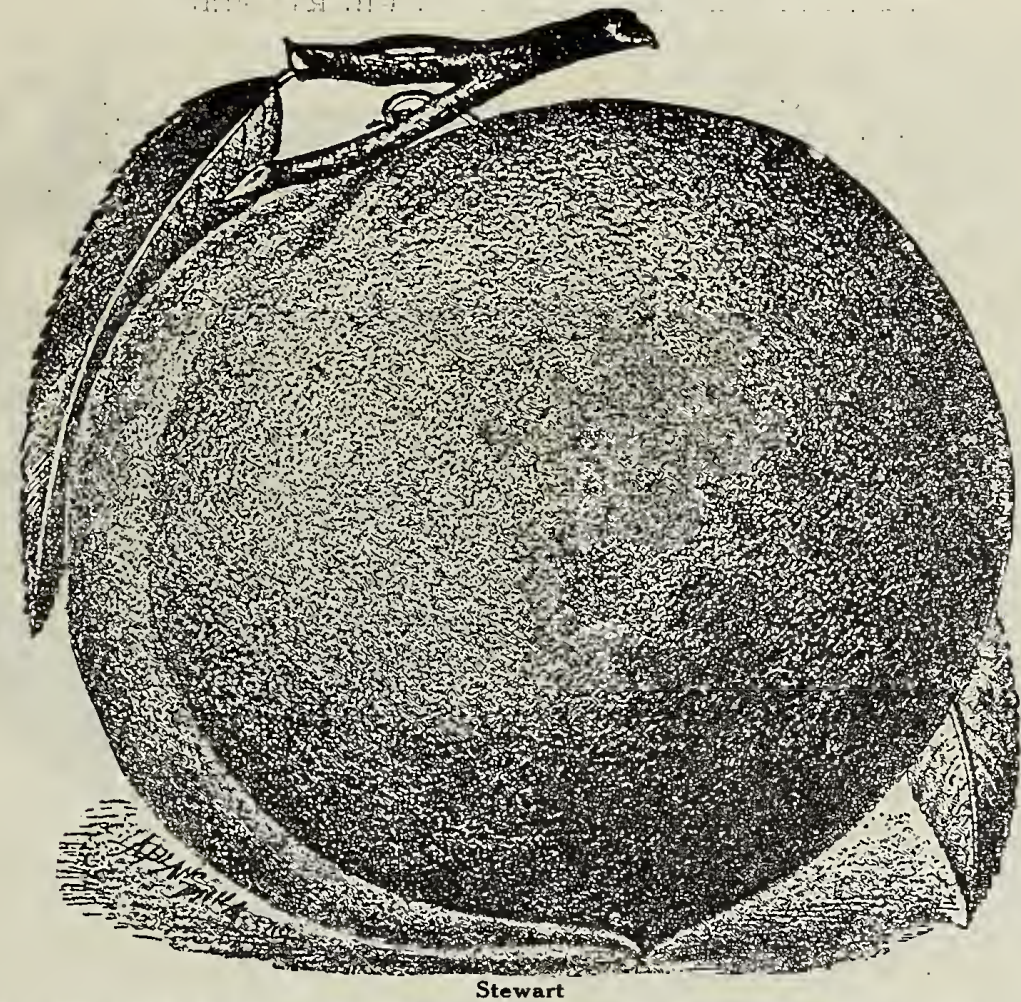

Stewart Peach-The seed was brought from a ranch in the Wasatch Mountains near the center of Utah, to Moab, by the Morman bishop, Suewart, and planted in his orchard twenty years ago. Fruit large to very large, free stone, of ten weighing twenty ounces. Color dark yellow, flesh yellow, with red near the stone, fine grained, juicy and delicious. Ripens ten days later than late Crawford. The tree is stout, stiff upright grower and very vigorous, strong leaves, very large and rough, an immense bearer and by far the hardiest tree grown here. $\quad$ Per 1 Per 10

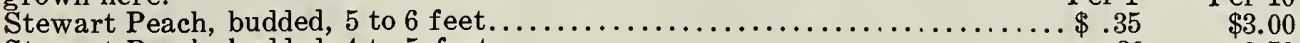

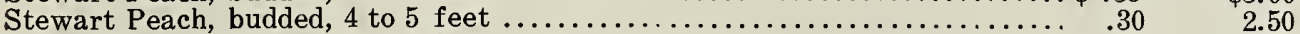

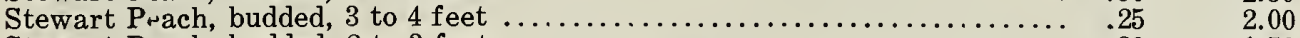

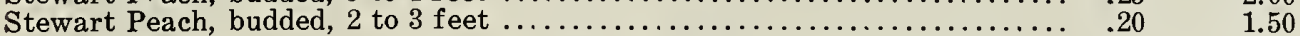

\section{PLUMS}

Diseases and Enemies of the Plum-The prevalence of the disease of the plum commonly known as the "Black Knot," which has so much discouraged people in the eastern states from giving to the plum its merited share of attention, has as yet done but little damage west of the Mississippi river; but its appearance should be guarded against, and its ravages prevented by keeping the trees in healthy condition, which is done by good cultivation and removing the knot by amputation on its first appearance. Nothing is more favorable to the growth of the black fungus or knot than neglect. But the great enemy of the plum is the insect known as the Curculio, a small, dark brown beetle which punctures the fruit in depositing its egg from which is hatched the destructive grub, and causing the fruit to drop prematurely an 1 rot. Two ways of destroying this Curculio and saving the crop of fruit is recommended, viz. :

First. Spread a large sheet prepared for the purpose under the tree and then jar the tree so as to shake down all fruits that have been stung, as well as all the Curculios; both insect and stung fruit are destroyed. Begin to do this as soon as the blossom falls, and keep it up daily, or at least tri-weekly until the fruit is half grown. The morning is the best time to do this when the insect is chilled and stupid.

Second. The best remedy and the one generally adopted now doubtless is the spraying of the trees, directions for wh ch are given in the last pages of this catalogue. If those who really desire to grow fine crops of this most delicious fruit will try either of these systems and follow it up rigidly they will be successful.

Per 1

5 to 6 feet, 3 years, fine trees....................... $\$ .40$

4 to 5 feet, 2 years, well branched $\ldots \ldots \ldots \ldots \ldots \ldots \ldots \ldots \ldots \ldots \ldots . \quad .30$

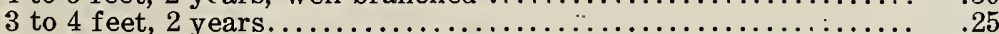

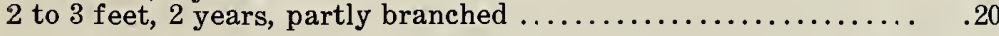

Per 10 Per 100

$\$ 3.50 \$ 3200$

$2.50 \quad 22.00$

$2.00 \quad 18.00$

$1.50 \quad 12.00$ 
Abundance-Of medium size, large when thinned, amber with markings of red, juicy, sweet, of good quality when well ripened. May be picked when it begins to color, will keep a long time, color well and be almost as rich and sweet as if ripened on the treea strong point for market growers. Usually the fruit must be thinned to prevent overbearing. August.

Burbank-The best of all the Japan sorts of plums, nearly globular, clear cherry red, and with a thin lilac bloom. The flesh is deep yellow color, very sweet, with a peculiar and very agreeable flavor, tree vigorous, w it h strong, upright shoots, large broad leaves, commences to bear usually at two years. It blooms late, and consequently more liable to escape the late spring frosts.

Wolf-Fruit nearly as large as Lombard, and a perfect free stone; quality superb for cooking and for serving with sugar; tree a good grower, hardy and is becoming very popular wherever known, promising to lead all other native plums. August.

Lombard-Medium, round, oval, violet red, juicy, pleasant and good, adheres to the stone, productive. A valuable market variety, one of the most hardy and popular. Last of August.

Wild Goose-Large, rich, crimson, beautiful flesh, soft, rich, melting, delicious, with a full fruit flavor; tree a strong grower, prolific. This variety is among plums what the Ben Davis is among apples-referring to the American class of plums. July.

Forest Garden-Large, nearly round, mottled red and yellow; juicy, very sweet and rich, tree a strong grower. July. ductive.

De Soto-Medium, bright red, sweet, rich, of fine quality. Extremely hardy and pro-

German Prune-A large long, oval variety, much esteemed for drying, color dark purple, of very agreeable flavor. September.

Santa Rosa-One of the latest creations of Luther Burbank, the wizard of horticulture. As yet we have only a limited stock of this new variety.

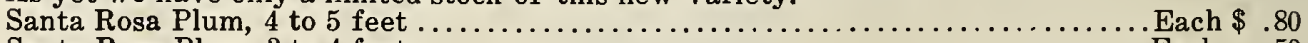

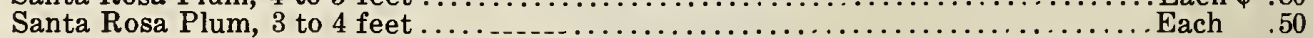

\section{CHERRIES}

A great deal of attention is now given to the growth of cherries in the West and no well planted home orchard is complete without its proportion of cherry trees, and it is one of the most prolific of garden fruits. It will succeed in any kind of soil that is not wet.

It may be planted near the street, or used to line avenues as an ornament, and it will at the same time produce an abundance of delicious fruit. This may be eaten out of hand, preserved, or it will find a ready market at highly profitable prices, for shipping, canning, etc.

Our cherry trees are budded on Mahaleb cherry stocks, which do not sprout from the roots. Care must be taken in planting that the trees are not planted too deep. One inch deeper than where budded is deep enough; should they be planted deeper than this, the tree will be liable to throw out roots above where budded, and these roots if broken will throw up sprouts or suckers.

Plant trees twenty feet apart, keep the main leaders headed back the first two or three years after transplanting. By so doing you will have fine, bushy tops near the ground, which will be of great advantage in picking the fruit. $\quad$ Per 1 Per $10 \quad$ Per 100

5 to 7 feet, 4 years, extra large........................ $\$ .50$

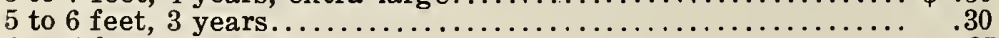

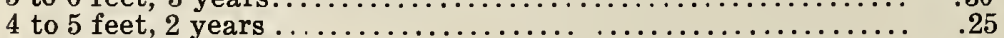

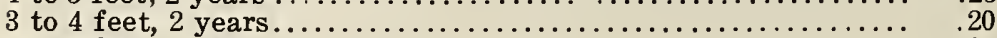

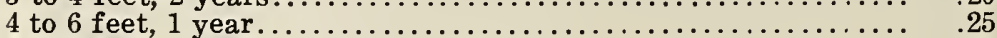

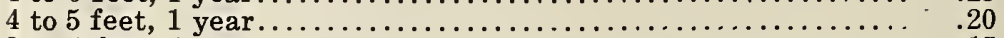

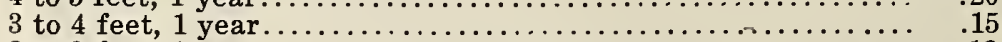

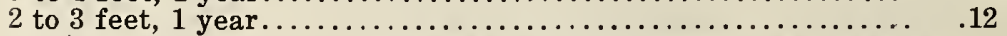

WE PAY THE FREIGHT. See page 4

$\begin{array}{rr}\$ 2.70 & \$ 25.00 \\ 2.20 & 20.00 \\ 1.70 & 15.00 \\ 2.20 & 18.00 \\ 1.80 & 15.00 \\ 1.30 & 12.00 \\ 1.10 & 10.00\end{array}$


Dye House-This variety partakes both of the Murillo and Duke, wood and fruit; a very early and sure bearer; ripens a week before Early Richmond, of better quality and quite as productive. May and June.

Early Richmond-(Kentish, Virginian or Early May)-Medium size; dark red; melting, juicy, sprightly, acid flavor. This is one of the most valuable and popular of cherries and is unsurpassed for cooking purposes, and is exceedingly productive. First of June.

Large Montmorency-A large, red, acid cherry, larger than Early Richmond and fully ten days later. Middle of June.

English Murillo-Tree slow grower but very abundant bearer; , very hardy; fruit slightly conical, dark red, almost black when fully ripe. Three weeks later than Richmond; most prolific.

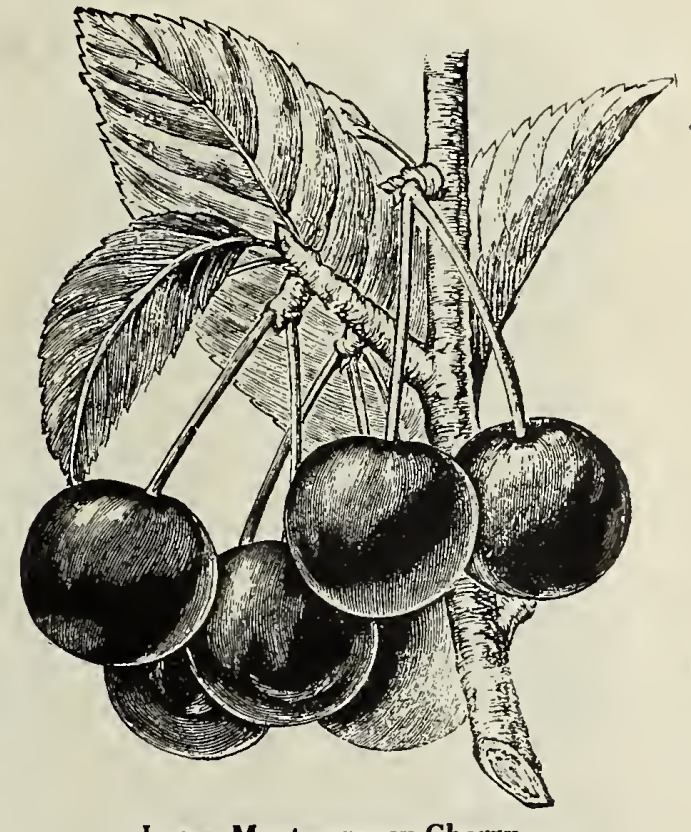

Large Montmorency Cherry

Ostheim-A hardy cherry from Russia. It has been tested in the severest winters of Minnesota, and has been found perfectly hardy. Fruit roundish, large, ovate; skin red, dark at maturity; stems long; flesh liver color; tender, juicy, almost sweet.

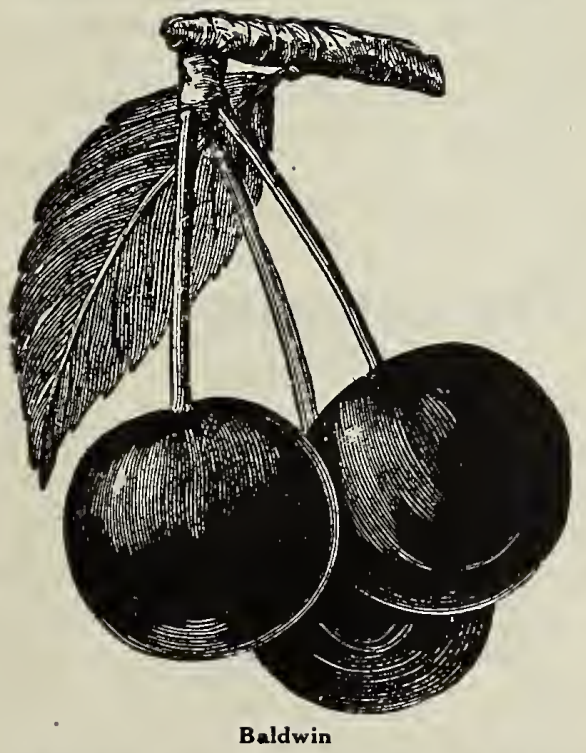

Black Tartarian-Large, juicy, rich, mild and sweet, vigorous and productive. Early.

Governor Wood-Large, yellow, shaded with light red, juicy, very delicious. A vigorous grower and very productive. Early Sweet.

Baldwin Cherry-The tree is an upright grower, more inclined to be round than otherwise; a very rank, vigorous grower, leaves rather broad; bloom pure white, which turns to a pink color, similar to the hydrangea; fruit very large, almost perfectly round, very dark, yet almost transparent; flavor slightly sub-acid, yet the sweetest and the richest of the Murillo type; stems rather large, of medium length; more inclined to grow in pairs than in clusters. It is remarkable for earliness, vigor, hardiness, qualiiy and productiveness. It is a tree to command attention, and is so distinct as to attract comments from any upon seeing it, without knowing its superior merits.

Per 1 Per 10

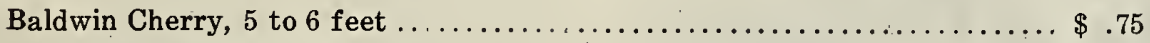

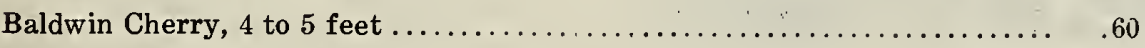

Baldwin Cherry, 4 to 5 feet .................................. .45

Baldwin Cherry, 2 to 3 feet 


\section{Quinces}

Owing to the negligence of the cultivator, this valuable fruit is seldom seen in perfection, being mostly allowed to grow without the least attention or cultivation. The Quince requires a good, deep soil, which should be clean and mellow, with an occasional dressing of manure and a sprinkling of salt; but does not need a severe pruning like many other varieties of fruit; a careful thinning out of the old decayed wood will be sufficient. Keep a vigilant search after the borer.

Apple, or Orange-This popular old Quince is one of the most reliable varieties for market. Large to very large, roundish, with short neck; golden yellow flesh firm and of fine flavor. October.

Bourgeat-A new kind, keeping well into midwinter. Very large, roundish, golden yellow; smooth and tender when cooked. Tree of remarkably strong growth and very productive. October to February.

Champion-Noticeable for its early bearing and superb appearance. Very large, mostly oval; deep yellow; excellent quality. Tree very prolific and vigorous. A good keeper.

Meech's Prolific-One of the valuable newer varieties, bearing when quite young. Large, roundish, pear-shaped; bright orange; fragrant and of excellent quality. Very productive. Ripens in midseason.

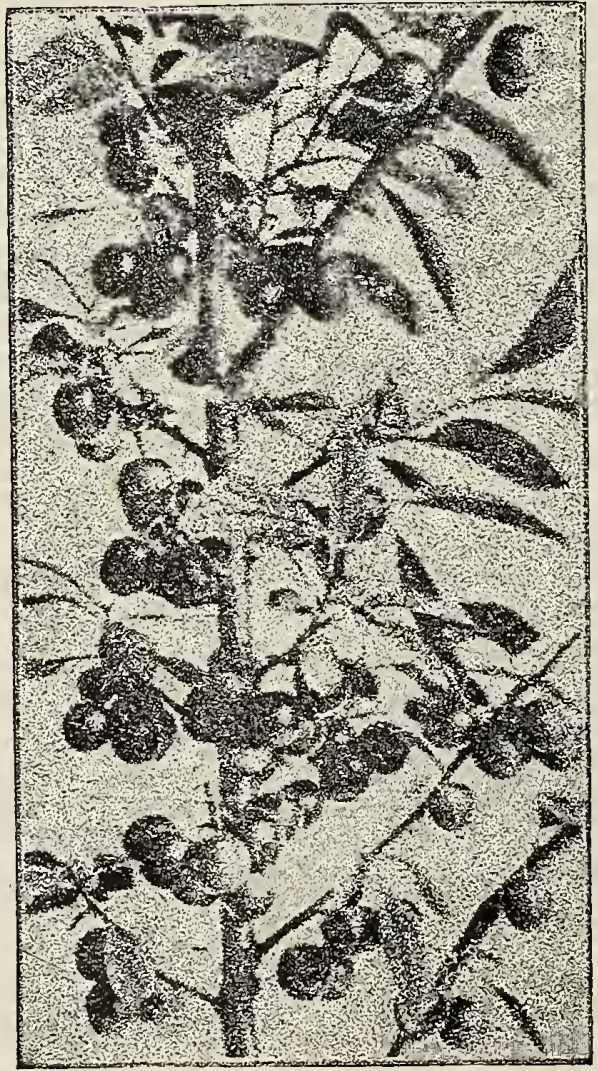

Fruiting branch of young Compass Cherry Tree showing the cherry-like foliage and the fruit combining the characteristics of both the plum and cherry.

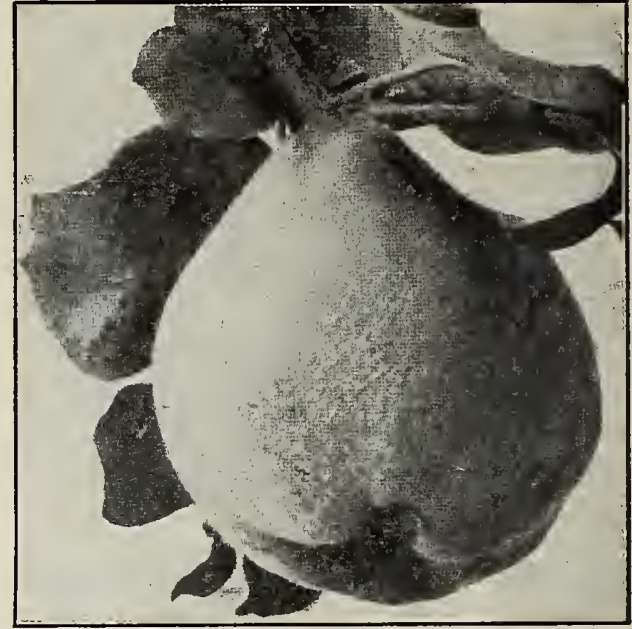

Ray's Mammoth-From Green county, N. York., and a superb variety. Large, roundish, with short neck; golden yellow, very beautiful; quality excellent. Strong grower and productive. October.

Per 1 Per 10

3 to 4 feet, well branched....\$.35 $\$ 3.00$

2 to 3 feet, partly bronched.. . $30 \quad 2.50$

\section{The Compass Cherry Plum}

The Compass Cherry-Plum originated with H. Knudson of Springfield, Minn., and is believed to be a cross between the Western Sand Cherry and the Miner Plum. Its habit of growth is like the Miner, while the leaf, twig and bark very much resemble the Sand Cherry. It is a strong grower, and makes a very fine orchard tree. Fruit about an inch in diameter, and is as much a plum as it is a cherry. The shape is oblong and slightly flattened. The pit is between the ordinary American plum and Early Richmond pit in shape and size. It has a flavor peculiar to itself, very palatable and rich. An immense and early bearer. Tree perfectly hardy as far north as Manitoba.

Per 1 Per 10

2 to 3 feet trees ..........\$.25 $\$ 2.00$

3 to 4 feet trees........... .35 $\quad 3.00$

4 to 5 feet trees........... .45 4.00

5 to 6 feet bearing size..... . .55 5.00 


\section{Cherry Rocky Mountain}

This is a novelty and a very profuse bearer, but the fruit is not as good as our leading sorts; grows in the form of a bush and is as hardy as Wyoming sage brush. It has stood 45 degrees below zero and unharmed in limb or fruit bud. Fruit about as large as English Murillo; cherry black when fully ripe; acid and very good for pie or wine. Season, July.

Two-foot trees $15 \mathrm{c}$ each; 10 trees $\$ 1.00$.

\section{Apricots}

A delicious fruit of the plum species, valuable for its earliness. It bears immense crops. Ripens July and August. Plant the same as peach.

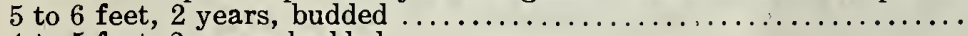

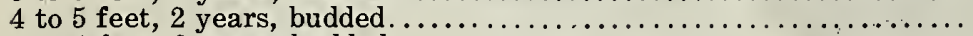

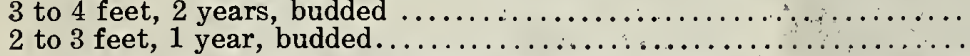

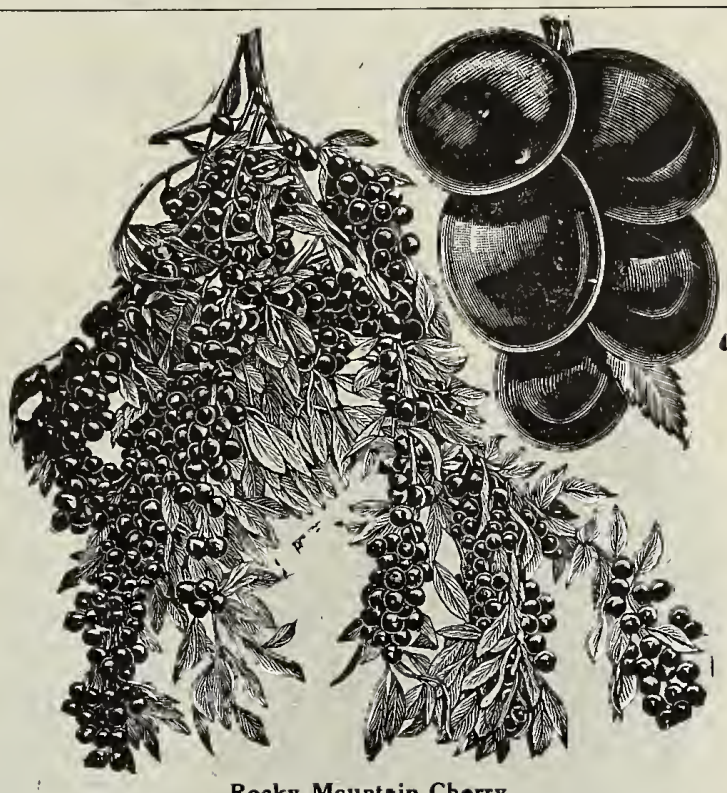

Rocky Mountain Cherry

Per 1 Per 10 Per 100

$\$ .35 \quad \$ 3.00 \quad \$ 25.00$

$\begin{array}{lll}.25 & 2.30 & 20.00\end{array}$

$.20 \quad 1.80 \quad 16.00$

$.15 \quad 1.40 \quad 12.00$

Superb-One of the largest; orange with red cheek; flrm, juicy with rich flavor; very productive. August. July.

Royal-Large; yellow with orange cheek; juicy, rich and delicious; a fine variety; last of

Moorpark-One of the largest; orange with a red cheek; firm, juicy with a rich flavor; very productive. July.

Russian Apricot $-\dot{A}$ new variety of recent introduction; valuable on account of extreme hardiness of trees and fine quality of fruit.

\section{Grapes}

The history of the grape is almost as old as that of man. Vineyards were extensively planted before orchards or collections of other fruit trees were at all common, and today it is one of the most highly appreciated fruits. In its flavor it is hardly surpassed by any other fruit in delicacy and richness, and few or none are more beautiful in the dessert Any person having a plot of ground ever so small, either in country or city, can find room for one-half to one dozen grape vines. They can be trained up by the side of any building or over a garden fence; but the best and cheapest way to grow them in small or large quantities is on the wire trellis.

Work the ground deep and plant a little deeper than they were in the nursery. Make rows eight feet apart and six to eight feet in the row. Some of them, the tender varieties, would be benefited by laying the vines flat on the ground during the winter, with a light covering of earth or litter.

Agawam, strong vines....................... 10

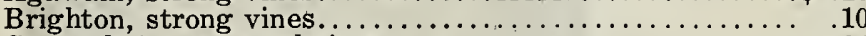

Concord, 1 year, good vines.................... 04

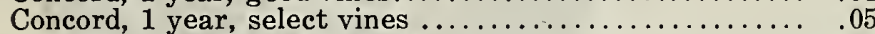

Concord, 2 years, select vines..................06

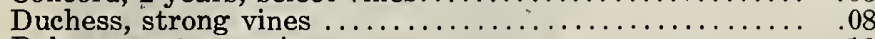

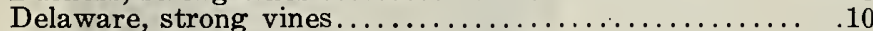

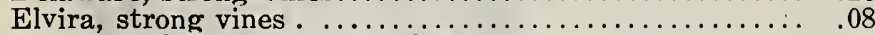

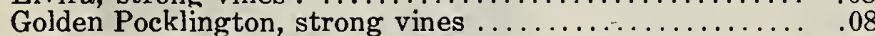

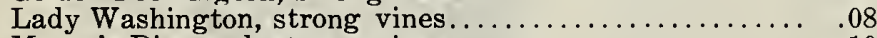

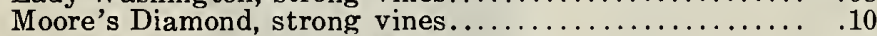

Moore's Early, strong vines . ...................... 10

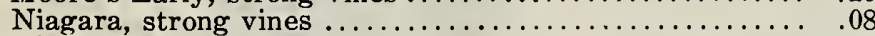

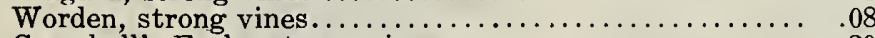

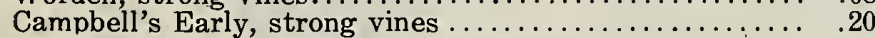

McPikes. .

Vines sent by mail for 2 cents each, extra.

$\begin{array}{rrr}\text { Per } 10 & \text { Per } 100 & \text { Per } 10000 \\ \$ .80 & \$ 5.00 & \$ \ldots \ldots \\ .80 & \ldots \ldots . & \ldots \ldots \\ .30 & 2.50 & 20.00 \\ .40 & 3.00 & 25.00 \\ .50 & 4.50 & 35.00 \\ .70 & 5.00 & \ldots \ldots \\ .90 & 8.00 & \ldots \ldots \\ .50 & 4.00 & \ldots \ldots \\ .70 & 5.00 & \ldots \ldots \\ .70 & 5.00 & \ldots \ldots \\ .90 & 8.00 & \ldots \ldots \\ .80 & 7.00 & \ldots \ldots \\ .70 & 5.00 & \ldots \ldots \\ .60 & 4.50 & \ldots \ldots \\ 1.50 & \ldots . & \ldots \ldots \\ 2.00 & \ldots . & \ldots \ldots\end{array}$


Concord-Bunches large, berries large, round, skin thick and covered with bloom; flesh juicy, sweet. Vine hardy, vigorous and productive; at present the most popular of all our native sorts.

Worden-This variety is a seedling of Concord, which it greatly resembles in appearance and flavor, but the berries are larger, the fruit is better flavored and ripens several days earlier. Black.

Moore's Early-A large black grape of the Concord type, the entire crop ripening before the Concord; bunch medium, berries large with blue bloom; flesh pulpy, of medium quality. Vine hardy, moderately productive, better as it attains age. Planted extensively as a market sort.

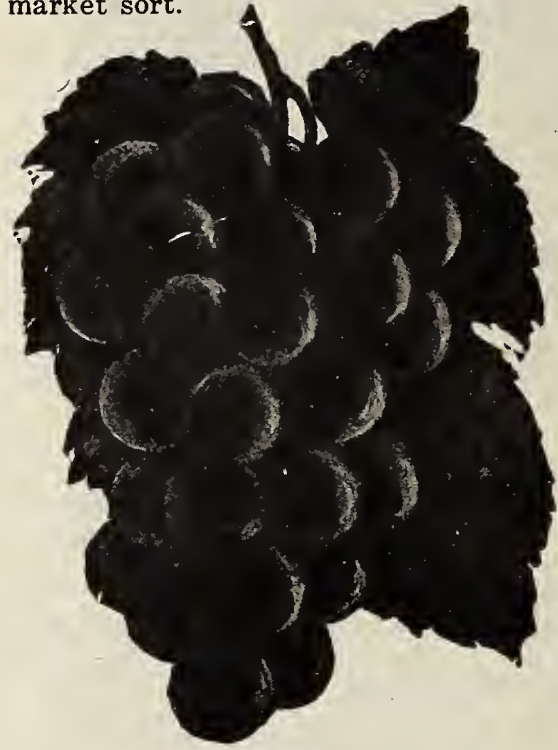

McPike

Agawam-Large, round, early and of great vigor of growth; rich, high, peculiar aromatic flavor, much subjected to disease and too highly flavored, where all its aroma is developed, to be desirable. Red.

Description of the McPike Grape-We have in this new, wonderful grape great size, wonderful quality, hardy wood and bud, very large leathery leaves. Fruit ripens same season as Worden, which is one week earlier than Concord. This grape ripens evenly, and only has one and two seeds; skin tender and pulp melting. This grape has taken all premiums at all the great state fairs in the fall of 1898 and 1899 wherever exhibited, over all competitors. Many testimonials could be printed, if space would permit, regarding the success of this wonderful vine.

Campbell Early-The king of grapes. The best all-round grape on the market. A very strong, hardy vine, with perfect, self-fertilizing blossoms, always setting its fruit well and bearing abundantly. Clusters very large, berries round and of great size, very sweet and rich. The seeds separate easily from the pulp. Ripens the first of August, but can be kept until December in cold storage; color black, with a light purple bloom.

Delaware-Still holds its own as one of the finest grapes; bunches small, compact, shouldered; berries rather small, round, thin skin, flesh very juicy, without any hard pulp; an exceedingly sweet, spicy, delicious flavor; vine moderately vigorous, hardy and productive. Red.

Brighton-A cross between the Concord and the Diana Hamburg. Bunches large, berries of medium size; flesh sweet, tender and of the highest quality; ripens early. Red.

Moore's. Diamond-Very hardy, healthy and vigorous; ripens from two to four weeks earlier than Concord. White.

Worden-(Black)-This variety is a seedling of Concord, which it greatly resembles in appearance and flavor, but the berries are larger, the fruit is better flavored and ripens several days earlier.

Niagara-A magnificent white grape and very valuable for both garden and vineyard, a rank grower and very productive of beautiful bunches of the largest size; berries large, with a tough skin; quality good. Ripens with Concord.

Lady Washington-Fruit yellow, tinged with pink; bunches very large, often weighing a pound; vine strong, very healthy.

Golden Pocklington-Is a seedling from Concord; vine hardy, both in wood and foliage; strong grower. Called a white grape, but the fruit is a light golden yellow; clear, juicy and sweet to the center, with little or no pulp; bunches very large, sometimes shouldered; berries large, round and thick set; quality, when fully ripe, much superior to Concord; ripens with Concord.

Elvira-Ripens about with Catawba. A very strong, healthy and robust grower; very productive; bunch and berry of medium size and very compact White.

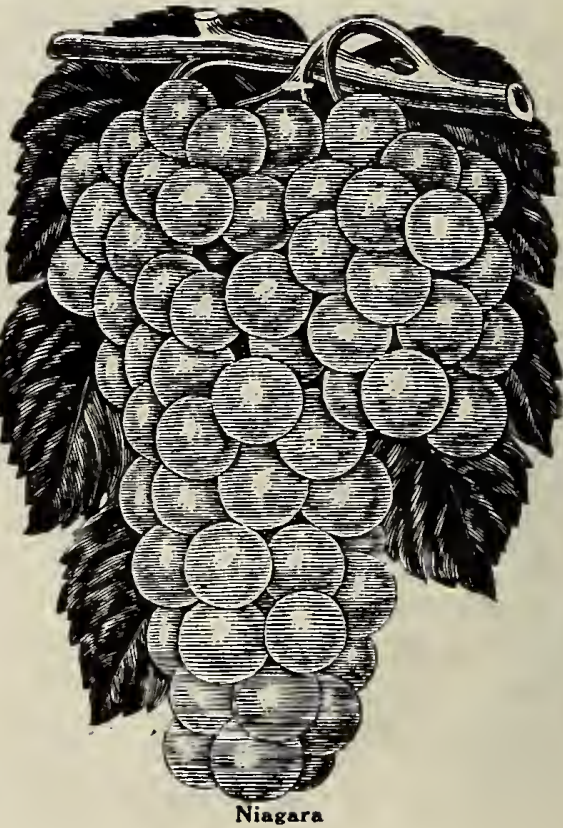




\section{Dwarf Service or June Berry}

Grows four to six feet high, bunches out from the ground like currants, resembles the Common Service or Juneberry in leaf and fruit, but the fruit is larger and in color almost black; commencing to bear the second year after transplanting and bears profusely. No farm or garden should be without this most excellent dessert fruit.

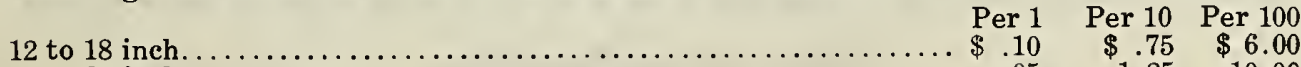

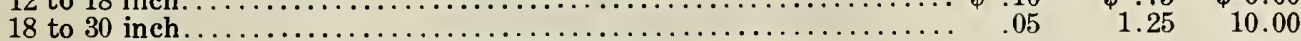

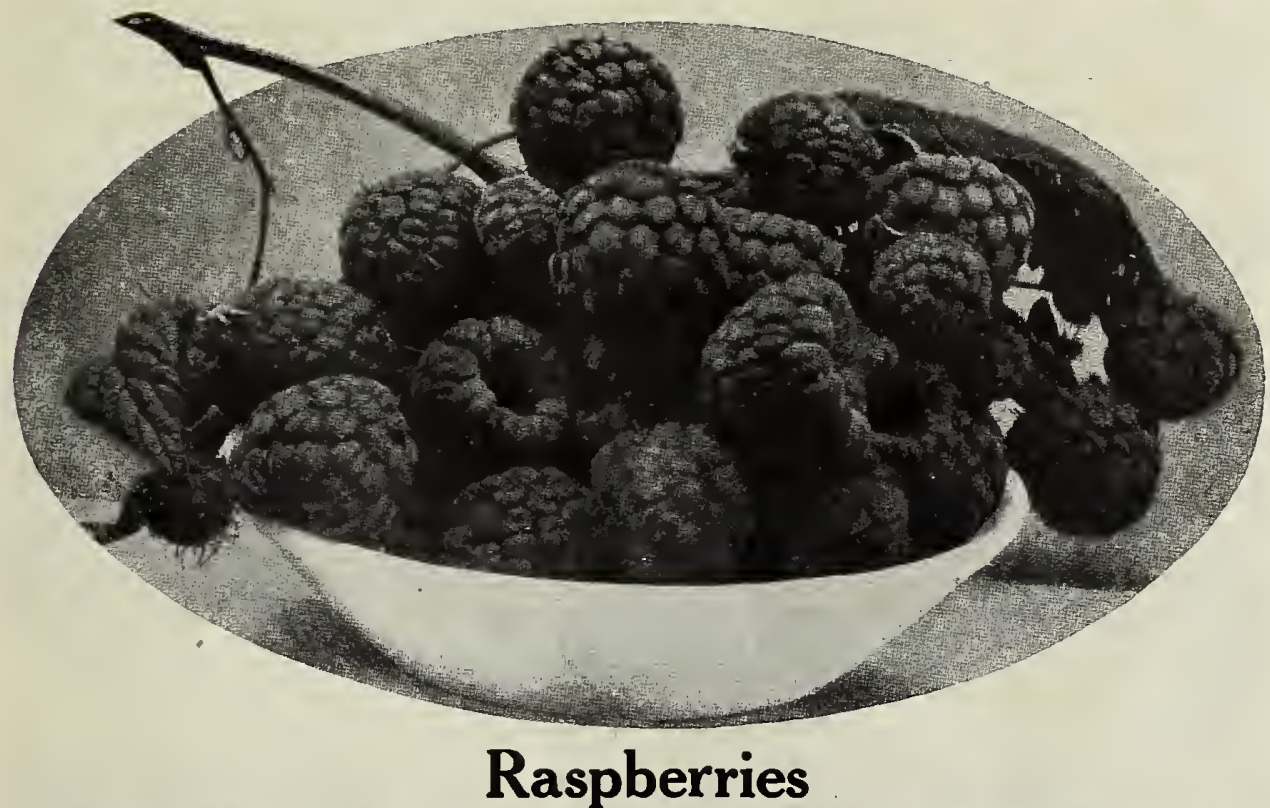

Raspberries should be set in the spring, plants $3 \frac{1}{2}$ feet apart in the row and rows 4 feet apart. Set plants 3 to 4 inches deep, depending on the soil (in heavy clay do not set as deep as on light soil), roots spread out and dirt pressed firmly among them. Give thorough shallow cultivation until last of July, or if you prefer mulch in with coarse manure or something of that kind, and keep the ground well stirred between the rows. When the new canes are about two feet high, pinch off the top; this will make the plant throw out side branches and do away with the necessity of tying up. In the spring eut these side branches back to 16 or 18 inches in length. Four or five good canes in a hill are enough. Cut out old canes as soon as through fruiting and burn them.

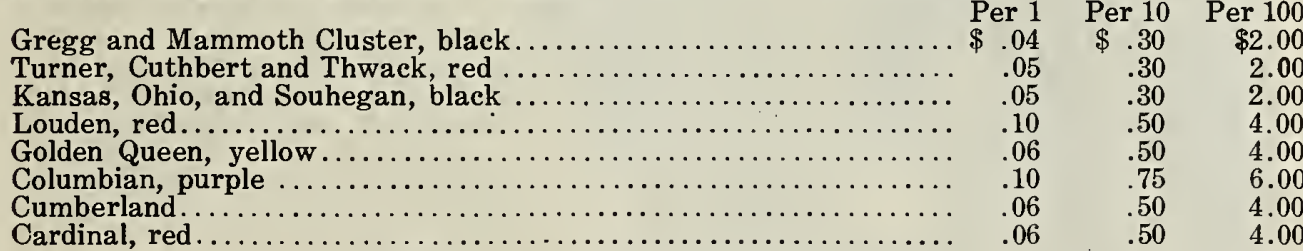

\section{Black Raspberries}

Gregg-Leading Black Cap and a popular market sort; canes of strong, vigorous growth, and uuder good culture very productive; berries are large, covered with heavy bloom, firm, meaty and of fine flavor. It requires a good strong soil to produce best results; it is not entirely hardy, but suffers during unusually severe winters; it is by far the best Black Cap and the largest of any.

Mammoth Cluster-A well known old variety, yet retained for its high quality and productiveness; rich and juicy, with much bloom; canes strong and vigorous; medium to late.

Kansas - Originated at Lawrence, Kansas. It is healthy, vigorous and not subject to leaf blight; produces strong, healthy tips; fruit large, as fine a berry as Gregg and equally as good a shipper; ripens just after the Souhegan; very prolific.

Ohio-Highly recommended for canning or evaporating and enormously productive; berry not quite as large as Gregg, but of finer quality and the plant more hardy and bears crop annually; claimed to be the most productive of all. 
Tyler (Souhegan) - A leading early market variety, ripening its entire crop in a very short time; medium size, very black, without bloom, flesh firm and sweet, plant vigorous, strong and hardy.

Cumberland-A mammoth mid-season Black Cap that loads its stout stocky canes with handsome fruit. The great glossy berries outsell all others of their season, and are firm enough to ship well. Excellent quality. Many berries are $7 / 8$ of an inch in diameter Hardiness, productiveness, size and quality make it desirable. Ripens a few days betore the Gregg.

\section{Red Raspberries}

Cuthbert, or Queen of the Market-A remarkably strong, hardy variety, standing the northern winters and southern summers equal to any. Berries very large, conical, rich crimson; flavor is sweet, rich and luscious.

Thwack-Canes short, hardy as the hardiest, producing large crops of beautiful fruit; very firm, rendering it one of the best for shipping.

Louden-A seedling of Turner crossed with the Cuthbert; originated at Janesville. The fruit is large, resembling the Cuthbert in color and shape, but is firmer and of a good quality; its fine appearance always commands the highest price in the market. The cane is strong, a vigorous grower, and resembles the Turner in appearance; is very hardy and productive. We believe it is the one red raspberry for the garden and market.

Turner-A beautiful red berry of fine size and excellent quality. One of the hardiest and most productive varieties known.

Golden Queen--Best yellow raspberry yet introduced. Briefiy stated, it is a yellow Cuthbert of large size, great beauty, high quality, hardy and productive. Canes are of the strongest growth; no home garden complete without it; its beauty, size and quality render it indispensable for table use. Ripens in midseason.

Columbian-(Purple)-This is the most vigorous grower of any raspberry in cultivation. The canes of ten reach one inch in diameter. No berry will surpass it for yield. The berries are very large, shaped like the Cuthbert, and are better quality than the Shaffer. The best berry for canning we know; it is different from any other raspberry.

Cardinal (Red) - The most remarkable plant of cane growth yet introduced; canes not injured by temperature of 26 degrees below zero; color dark red, almost purple; very productive; berries large and round. The best of its kind.

\section{Logan Berry}

Or Raspberry Blackberry-Originated in California in 1884 . Supposed to be a cross between a red raspberry and a blackberry. In California for several years it has been grown in quantity for market and has been well tested in eastern states. Vlne is a strong grower, spreading like Dewberry, free from disease; canes large, exceedingly prolific; ripens very early. Fruit size of large blackberries, same form and shape; color bright red, seeds small, flavor combination of blackberry and raspberry; mild, pleasant, vinous, excellent. Twenty cents each, six for $\$ 100$.

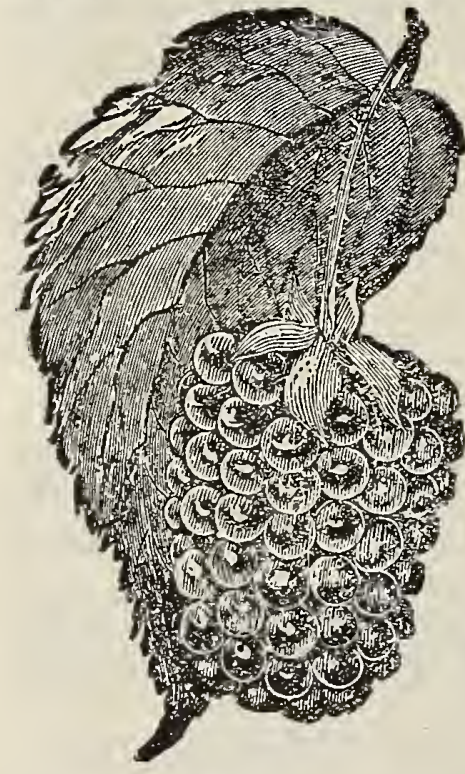

Lucretia

\section{Strawberry-Raspberry}

Strawberry Tree-A very beautiful fruit from Japan. Bush from 18 inches to 2 feet in height, entirely hardy and impervious to heat and drought. The berries are larger than the largest strawberries, bright shining scarlet with an exquisite bloom. An immense yielder, producing regularly and abundantly. It bears the first season and gets stronger and larger each year. All lovers of fruit should give it a trial. It will both surprise and please you. Fifteen cents each, six for 80 cents.

\section{Dewberries}

Price 5 cents each, 40 cents for $10, \$ 3.00$ for 100 .

Bartel's Mammoth-Fruit very large, luscious and handsome; perfectly hardy; a strong grnwer and enormously productive; a superb and very profitable market fruit. The vines should be allowed to lie on the ground in winter and staked up early in the spring.

Lucretia-This is the leading and most popular dewberry yet discovered; it succeeds everywhere and is not particular about the kind of soil. Berries very large, black and of fine flavor. It should not be picked oftener than twice a week, when it is very sweet and rich; it ripens with the last strawberries. 


\section{Blackberries}

In field culture plant in rows 8 feet apart and 3 feet in the rows. In garden culture plant rows 5 feet apart and 3 feet distant in rows. The pruning should be governed by the growth of cane and should be severe. Pinch back the canes in summer when 3 feet high, causing them to throw out laterals. Cultivate for first season to get plants well established, then the ground between the rows may be mulched enough to keep down all weeds.

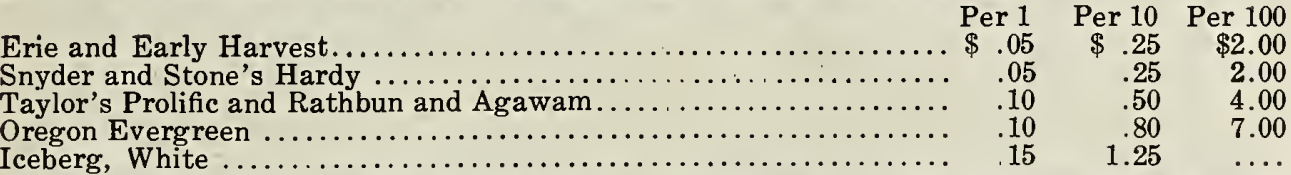

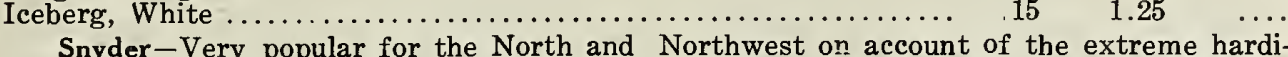
ness. Wonderfully productive, size medium, fruit juicy and sweet, without the hard core of many sorts; canes remarkably strong and thrifty; more largely planted than any other of the ironclad varieties. We have a heavy demand for them every year. Season early.

Stone's Hardy-Upright grower; very hardy; the berry is black and glossy when ripe and has a delicious flavor. It commences to ripen its fruit about five days earlier than Snyder, and continues bearing ten days longer.

Rathbun-A strong, erect grower with strong stem, branching freely; will root from tip of branches like a raspberry. Hardy, having endured 20 degrees below zero and produced a good crop. Forms a neat, compact bush 4 or 5 feet high, producing its immense fruit abundantly. Fruit is sweet and luscious, without hard core, of extra high flavor; jet black, small seed, firm enough to ship and handle well.

Early Harvest-One of the earliest blackberries in cultivation, a compact dwarf grower, fruit rather small and of good quality, heavy bearer; its extreme earliness makes it a very profitable variety. Bloom stands the spring frosts best of all.

Oregon Evergreen - The Oregon Evergreen Blackberry is one of the good thlngs that have come to stay with us and will prove a great boon to all lovers of the wholesome and luscious fruit. Everyone who has a dooryard or piece of ground, however small, can now have plenty of the sweetest and best blackberries at little trouble or cost, as this valuable new variety will thrive and bear immense crops of the most luscious fruit wherever it can get a foothold in the soil, and any kind of a trellis, arbor or support for the magnificent grape-like vines to run over. The Oregon Evergreen Blackberry differs from all other blackberries in form of its foliage and manner of growth. The canes do not die in winter like other blackberries, but continue to grow and bear year after year like a grapevine. The foliage somewhat resembles that of the fern and forms a remarably handsome covering for arbors. The berries are borne in clusters of four or five on a stem, are good sized, fine flavored, sweet

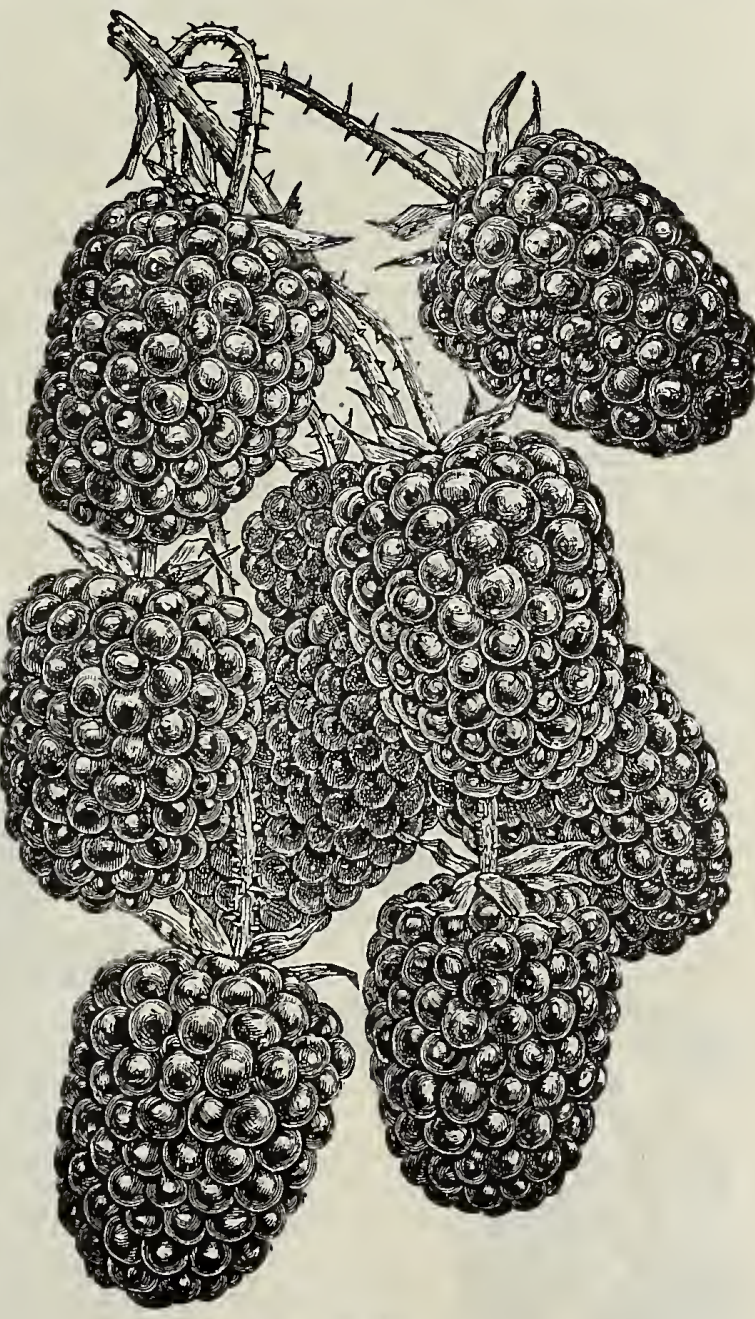

Oregon

and delicious, either to eat from the hand, canning or cooking. They are immensely productive. No other blackberry will bear such heavy crops and continue fruiting so long in the season. 


\section{Currants}

A cool moist location is best for this fruit, and for this reason it succeeds admirably when planted by a stone wall or fence, being benefited by partial shade. Plant in rows four feet apart and the plants three feet apart in the rows. They should be pruned each year, and all dead wood cut from them. Keep them thinned out so that air can freely pass through them. Currant worms can be destroyed by the use of hellebore. Dissolve an ounce in three gallons of water, and apply with a syringe or small sprinkling can. This can be done with very little expense if performed at the right time.

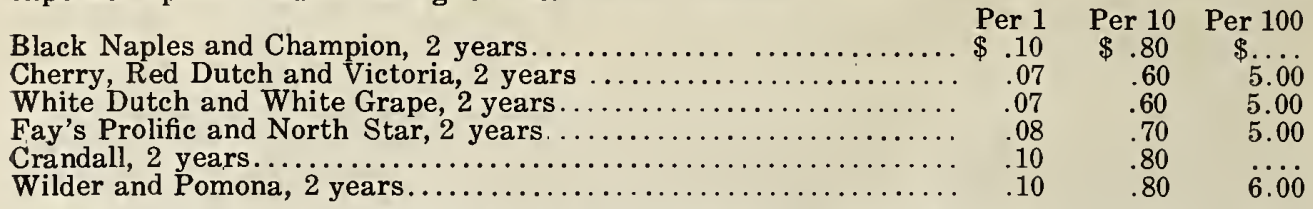

Fay's Prolific-Color a deep red; a great bearer; stems longer than Cherry and berry holds its size to the end of the stem better; quality first-class; not quite so acid as Cherry. Claimed to be the most prolific of all red currents.

Black Naples-Very large, sometimes measuring half an inch in diameter; fine for wines and jellies.

Black Champion--Bunches are very large and the flavor of the fruit particularly delicious; it hangs long on the bunches.

Pomona-Medium size, a clear bright red; excellent quality; hangs long time after ripe; holds up well on market; is one of the best for shipping; easily and cheaply picked; holds an unparalleled record for actual acreage yield in ordinary field culture.

Cherry-The largest of all the red currants, berries sometimes measuring half an inch in diameter; bunches short; plant very vigorous and productive when grown on good soil and well cultivated.

Red Dutch-The standard old variety, excellent and well known, a great bearer and a very profitable market sort.

Victoria-Large, bright red, with very long branches; late, good bearer.

White Grape-Very large, yellowish white, sweet or very mild acid; excellent quality and valuable for the table, the finest of the white sorts, very distinct from White Dutch, having a low, spreading habit, and dark green foliage. Very productive.

Crandall-A native black seedling of the Western Wild Currant, and much superior to any of the named varieties yet introduced, distinct from the European black varieties, and without their strong odor; wonderfully productive; a strong grower, usually producing a crop next year after planting; large size, $\frac{1}{2}$ to $\frac{3}{4}$ inch in diameter; easily picked; can be shipped farther and kept longer than any other small fruit; free from all attacks of insect enemies.

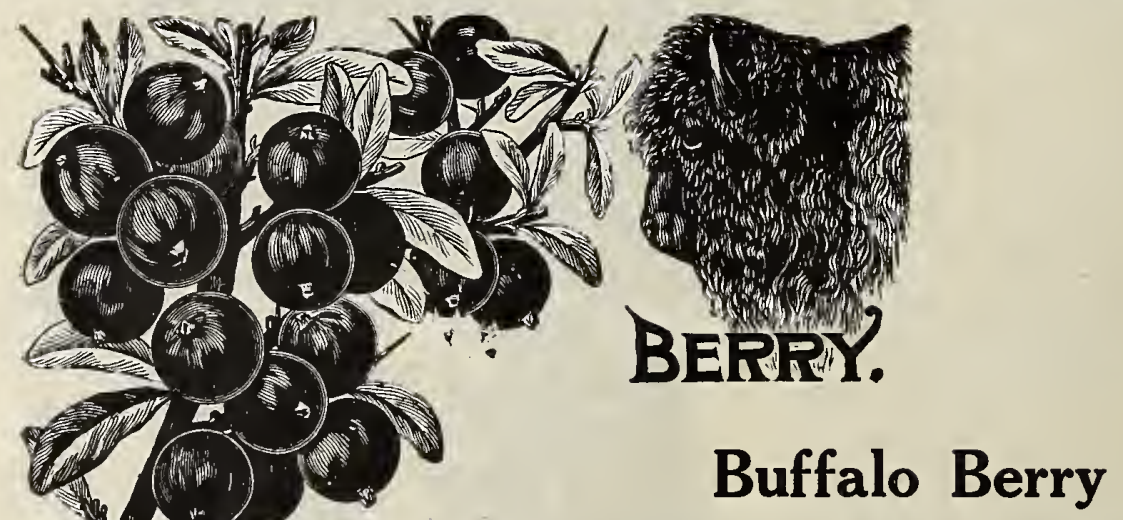

The Buffalo Berry belongs to the Olive family of trees. 1t grows in bush form and sometimes attains a height of ten feet; its leaves are of bright, silvery color, and, with its load of red fruit, makes a nice shrub; it is perfectly hardy, and bears immense crops of fruit, which is very good for tarts, jellies, pies and preserves.

It is sometimes called the winter currant, from the fact that fruit remains on until January.

Price-2 foot trees 20 cents each, 6 for $\$ 1.00$. Bearing size, 4 to 5 feet, 50 cents each, 6 for $\$ 2.50$. 


\section{Strawberries}

The ground should be worked 10 or 15 inches deep and be properly enriched as for any garden crop. Drainage is necessary in very wet soil.

For family use plant fifteen to eighteen inches apart each way, and after a few strong plants have been set from runners, then pinch off all runners as fast as they appear. Keep the ground free from weeds and frequently stirred with a hoe or fork. Plants treated in this manner will produce more crowns and therefore double the amount of well-developed fruit than when runners are left to grow.

When the winters are severe, it is well to give the ground a light covering with coarse straw or litter, The covering should not be placed on until the ground is frozen. Fatal errors are made by putting on too much and too early. If coarse straw is used, it may be left on until the plants have done fruiting, taking care to open it up around the plants early in the spring, so as to give them plenty of sunlight and air.

Price-1 cent each; 60 cents per hundred; $\$ 400$ per 1,000 .

Price in September and October $-\$ 1.00$ per hundred; $\$ 6 ; 00$ per 1,000 .

Price in July-Potted plants, from 2 inch pots, shipped with the earth attached, every one will grow, 5 cents each, $\$ 4.00$ per 100 .

Beder Wood (Per.) - It ripens a week ahead of Crescent, gives heavy pickings from the start, and holds out until the rush of mid-season.

Senator Dunlap (Per.) - A well-tested, wonderfully productive variety, one of the safe sorts to plant anywhere and sure to take a high place among the prominent standard sorts. Plants resemble Warfield, rampant runner, should be restricted in its production of plants, fully equal to Crescent and Warfield in its ability to succeed under all circumstances Fruit good size, regular, form, beautiful bright red, glossy, firm, splendid keeper and shipper, excellent quality; one of the best for canning; ripens early and continues a long time. It promises to stand at the head in its wonderful ability to ripen a good crop under almost any condition of drouth or neglect.

Crescent-Perhaps the must popular of them all. Plants strong, hardy and very productive; fruit extremely large, dark red, fine flavor. A splendid market variety. Imperfect.

\section{Gooseberries}

In order to produce large, abundant crops of gooseberries, it is necessary to manure heavily and prune closely. The English varieties do not require much pruning. Mildew is prevented by close planting and heavy mulching. Plant 3 to 4 feet each way.

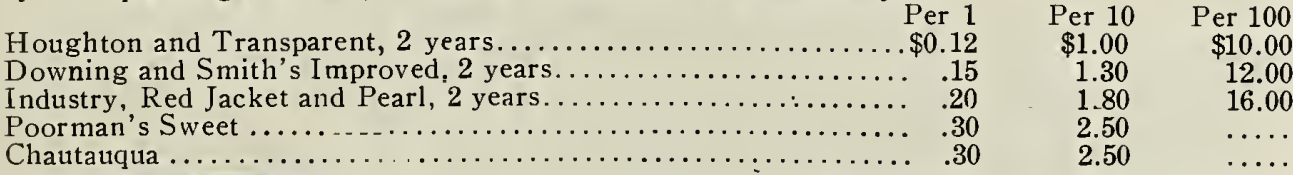

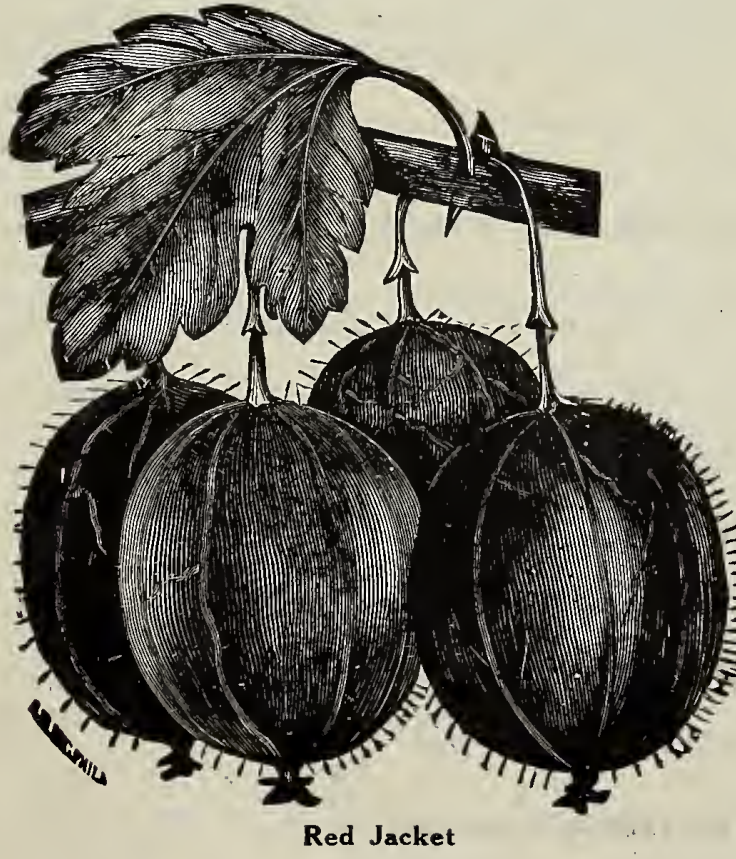

Red Jacket-An American seedling of large size, smooth, p:olific and hardy of the best quality; has been well tested over a wide extent of territory. A wonderful cropper, with heavy foliage.

Downing-Fruit larger than Houghton; roundish, light green, with distinct veins, skin smooth, flesh is rather soft, juicy and very good. Vigorous and productive.

Houghton-A medium sized American variety, which bears abundant and regular crops, and never mildews. Fruit smooth, tender and good. Very valuable.

Industry--The best English gooseberry yet introduced, of vigorous upright growth and a greater cropper than any known variety, and much less subject to mildew than other English varieties, berries of the largest size, one and onehalf inches in diameter, and of the most excellent flavor, both pleasant and rich, color when fully ripe, dark red. 
Poorman's-It is so called from the fact that when ripe is perfectly sweet, like sweet cherry, and requires little, if any, sugar for culinary purposes. This most remarkable gooseberry is a seedling from Houghton and is as hardy as its parent. It is a very strong grower, the bushes being inclined to grow in tree shape. It is red when ripe, very large, and has a shape and flower like a plum.

Chautauqua-This is a new variety of exceptional merit. Bush very vigorous, stout, upright, foliage large, glossy, dark green. Fruit large, light greenish-yellow, smooth, translucent, thick skinned, Quality very sweet and highly flavored. Very hardy and a prolific bearer.

\section{Japanese Wineberry}

This is an entirely new, distinct and valuable berry. It belongs to the raspberry family, is a strong vigorous grower, attaining the usual height of the raspberry, and is said to be perfectly hardy in all positions without protection. The leaves are of the darkest green on the outside and silvery white underneath. The young shoots or branches are covered with a reddish brown hair or moss. The fruit is borne in large clusters, often 70 to 100 berries in a bunch. These berries are; from the time of formation and bloom until they are ripe, enclosed in a "burr" which is caused by the calyx covering them entirely. When ripe the burr opens, exhibiting a large berry of the brightest, light glossy scarlet or cherry wine color. The burrs and stems are covered with a heavy reddish moss like a moss rose bud. The flavor of the fruit is entirely different from that of any other berry, being very sprightly sweet and juicy, having no disagreeable sour, but a delicate and luscious flavor peculiar to itself, and superior to other berries. It commences to ripen early in July, and continues in bearing for a long time. It is the most prolific berry known, the bushes being literally covered with its luscious fruit. It is propagated from the tips like cap raspberries and dewberries, and can be increased rapidly.

Price -15 cents each; 12 plants for $\$ 1.00$.

\section{Asparagus}

To prepare a bed for planting, the soil should be dug deeply and well mixed together with well rotted manure or compost. Plant in rows two feet apart. In the rows the plants should not exceed a foot apart, and planted about four inches deep. Cover on approach of winter with manure, and fork the bed over lightly in the spring.

Price-10 cents per $10 ; 75$ cents per $100, \$ 6.00$ per 1,000 .

Conover's Colossal-A mammouth variety of vigorous growth, sending up from fifteen to twenty sprouts each year, from one to two inches in diameter; color deep green, and crown very close.

Palmetto-It is earlier, a better yielder, more even and regular in its growth and quality, equal to the old favorite, Conover's Colossal.

\section{Rhubarb or Pie Plant}

This deserves to be ranked among the best early vegetables in the garden. It affords the earliest material for pies and tarts, continues long in use, and is valuable for canning. Make: the border very rich and deep.

Price-10 cents per 1,60 cents per $10 ; \$ 4.00$ per 100 .

Linnaeus-Large, early, tender and fine; the very best of all.

Victoria-The best for market because of its giant growth.

\section{Horse Radish}

Price-3 cents per $1 ; 20$ cents per $10 ; \$ 1.50$ per 100 .

\section{Elderberries}

A well-known bush which bears a fine fruit for pies or wine.

Price -15 cents each; 10 for $\$ 1.00$.

WE PAY THE FREIGHT-See Page 5 


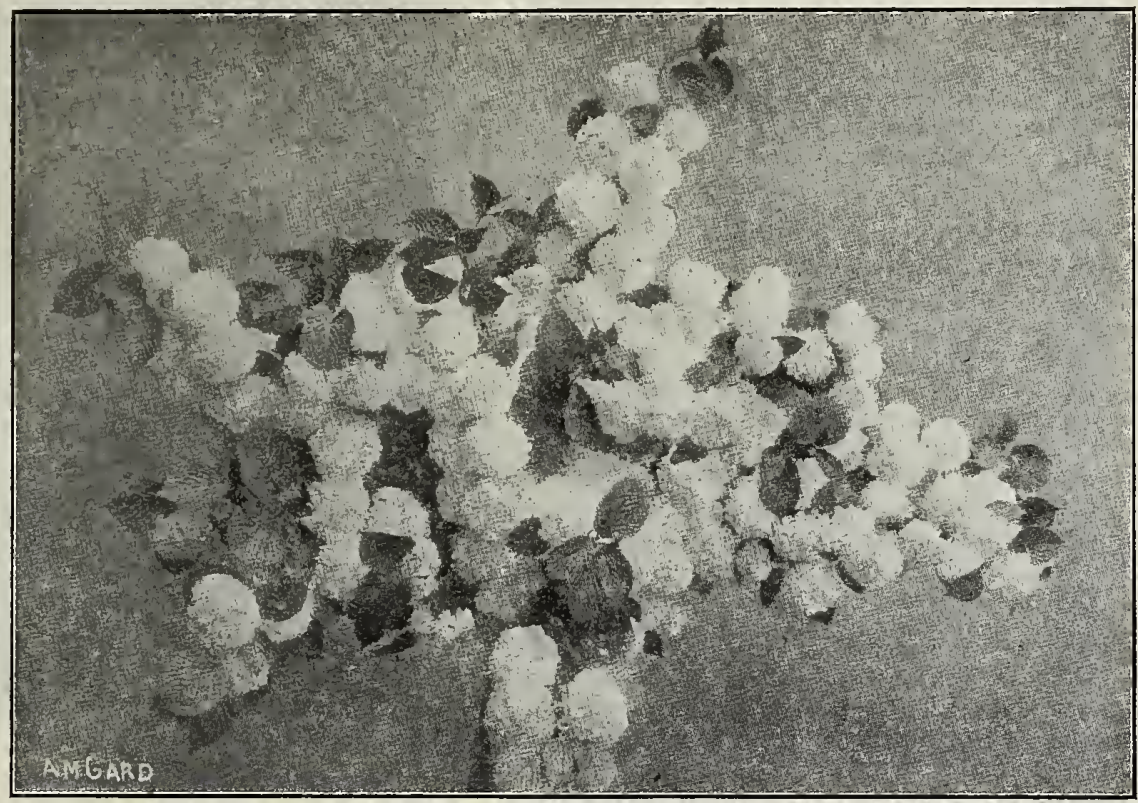

Japan Snowball

\section{Ornamental Shrubs}

The judicious planting of shrubs adds greatly to the beauty and value of property, and contributes a wealth of pleasure and interest to the home. There are a few principles governing the artistic arrangement of these beautiful ornamentals, that should be more strictly observed. In general, individual specimens, should rarely be isolated from the body of the design. Irregular groups or masses arranged against the buildings, fences or property lines, or as border plantations, along walks or drives, are much more effective. A good arrangement of shrubs invariably provides wide open stretches near the center of the lawn:

We have reduced our shrub list somewhat, omitting varieties for which, although very desirable in themselves, there is little demand.

Althea or Rose of Sharon-These are fine shrubs and especially valuable because of their fliwering in the fall when nearly all other shrubs are out of blossom. Hardy and easy of cultivation. 20 cents each.

Almond-Dwarf, double, rose-flowering. A beautiful shrub with small, double rosy blossom, closely set upon the twigs before the leaves appear. 20 cents each.

Japan Snowball-A rare and exceedingly beautiful species from Japan. Flowers pure white, in very large globular heads. 2 foot trees, 35 cents each.

Bechtel's Double-Flowering Crab-A medium-sized hardy ornamental tree of great beauty. When in bloom this tree presents the appearance of being covered with roses, fragrant flowers of immense size, sure to give satisfaction to those who plant this beautiful tree. 3 to 4 -foot trees, 35 cents each.

Calycanthus-Sweet Scented Shrub or Allspice-An interesting shrub having a rare and peculiar fragrance of wood and flowers, its blooms are abundant and of peculiar chocolate color. 25 cents each.

Mock Orange or Syringa-The Syringa is a large shrub, growing from 6 to 10 feet high. Vigorous habit, very hardy, with large handsome foliage and beautiful white flowers. Very fragrant. Blooms very freely. Hardy. 20 cents.

Snow Ball-A well known and favorite bush of large size. Bears balls of pure white flowers in June. We have a bush on our farm on which we counted over 800 blossoms at one time. Hardy everywhere. 20 cents each. 
Hydrangea - A fine shrub of recent introduction, blooming from July to November. Large, showy panicles of white flowers in the greatest profusion. It is quite hardy and altogether a most admirable shrub for planting singly on the lawn or in the margin of masses. To produce largest flowers it should be pruned severely in the spring and the ground enriched. 2-foot plants 25 cents each.

Tree Hydrangea-4 to 5 feet high, 50 cents each.

Spirea-(Nan Houttei)-The best White Spirea. The annual growth is long and abundant, and covered in June with a wealth of pure white blossoms. Perfectly hardy. Should be in every collection. 20 cents each.

Spirea-(Anthony Waterer)-A small dwarfish grower, 15 to 18 inches high and covered the entire season with large umbels of deep pink flowers. Quite hardy here and very desirable. 25 cents each.

Lilac, Persian Purple-A well known shrub of glossy green foliage and beautiful, fragrant flowers. A good plant for the lawn and one of the best for a fancy hedge. Hardy anywhere. Flowers purple. 20 cents each.

Lilac, Persian White-Same as above, with white Howers. 20 cents each.

Weigelia Rosea-Of Japanese origin, producing a mass of flowers from July until fall. Very ornamental, Howers dark rose with lighter center. Very hardy. 20 cents each.

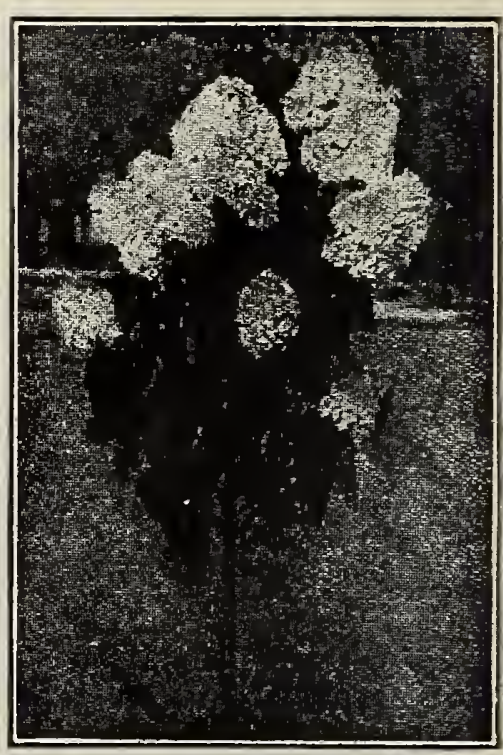

Tree Hydrangea

Weigelia-(Eva Rathke)-Brilliant carmine in color, almost continuous bloomer, very fine. Price 25 cents each.

\section{Climbing Vines}

Clematis Paniculata-(New Sweet Scented Japan Clematis)-No introduction of recent years has met with such ready sale and given so perfect satisfaction wherever planted. It grows and thrives anywhere and is a very rapid grower and profuse bloomer. The flowers are pure white. Its extreme hardiness, bright green foliage and delightfully fragrant flowers, serve to make this one of the finest hardy climbing plants in cultivation. Strong 2-year plants, 25 cents.

Clematis-(Jackmanii)-A very beautiful blooming variety, with flowers from four to six inches in diameter, of an intense violet purple color, borne successfully in continuous masses on the summer shoots. 35 cents each.

Henryi-Fine, large, creamy white flowers, strong grower and very hardy. One of the best of white varieties. A perpetual bloomer. 40 cents each.

Clematis-(Mad. Andre)-Red, very strong grower, producinglarge flowers. 35 cents each.

Honeysuckle-(Monthly Fragrant or Dutch)-Blooms all summer, very sweet. Red and yellow flowers. 20 cents each.

Bigonia or Trumpet Flower--(Scarlet Radicans)-A splendid climber, vigorous and hardy, with clusters of large trumpet-shaped scarlet flowers in August. 20 cents each.

Virginia Creeper-A native vine of rapid growth, with large luxurant foliage, which in the autumn assumes the most gorgeous and magnificent coloring. The blossoms, which are inconspicuous, are succeeded by handsome dark blue berries. The vine is the best calculated to take the place in this country of the celebrated English Ivy, and is really in summer not inferior to it. 25 cents each.

Wistaria-(Double Purple)-A rare and charming variety, with perfect double flowers, Jeeper in color than the single, and the racemes of remarkable length. The plant is perfectly hardy, resembling the single Wistaria, so well known as one of our best climbing plants. 20 cents each.

Boston Ivy - A beautiful hardy climbing plant. This is one of the finest climbers we have for covering walls, as it clings firmly to the smoothest surface, covering it smoothly with overlapping foliage, giving it the appearance of being shingled with green leaves. The color is a fresh deep green in summer, changing to the brightest shade of crimson and yellow in autumn. It is quite hardy and becomes more popular every year. Strong plants, 25 cents each.

Hall's Japan Honeysuckle - This beautiful honeysuckle is almost evergreen; very strong and hardy in growth. The flowers are delightfully fragrant, and bloom profusely from May until frost; a handsome and valuable vine. 15 cents each. 


\section{Roses}

The Rose has always held the foremost rank in the entire list of cultivated plants, and fairly earned the title of Queen of Flowers. We do not offer every variety known, but we do offer a superior assortment. that embraces all the desirable qualities anyone can justly expect in these lovely flowers.

In selecting a spot for a rose-bed, do not chose one that is shaded by trees or buildings, as the rose delights in an open, airy situation, and plenty of sunshine. Roses do well in any ordinary soil if enriched with well rotted barn yard manure, or leaf mold. Dig the bed up thoroughly to the depth of 12 to 15 inches.

Our roses are the best that can be grown, and with few exceptions are on own roots. A few varieties that do not readily propagate by that method, are budded. Healthy, hardy, thrifty bushes, that will grow and bloom.

\section{Climbing Roses}

Crimson Rambler-The famous crimson clustered climber, so extremely effective when grown on pillars and trellises. The plant is a vigorous grower making shoots 8 to 10 feet long in a season. The foliage is large and glossy, the plant looks like a mass of double crimson flowers when in bloom. The panicles are large and remain perfect for several weeks. Perfectly hardy anywhere. Price, 25 cents each.

Yellow Rambler-Flowers of medium size, in immense clusters, very sweet scented; a clear, decided yellow. The hardiest of all yellow climbing roses. It is a rampant grower, well established plants often making a growth of 10 to 12 feet in a season. 25 cents each.

White Rambler-Resembles Crimson Rambler in foliage and habit; flowers pure white. 25 cents each.

Baltimore Belle-Pale blush, is almost white; very double and fragrant. 20 cents each.

Greenville or Seven Sisters-Purplish crimson and pink, not quite hardy. 20 cents each.

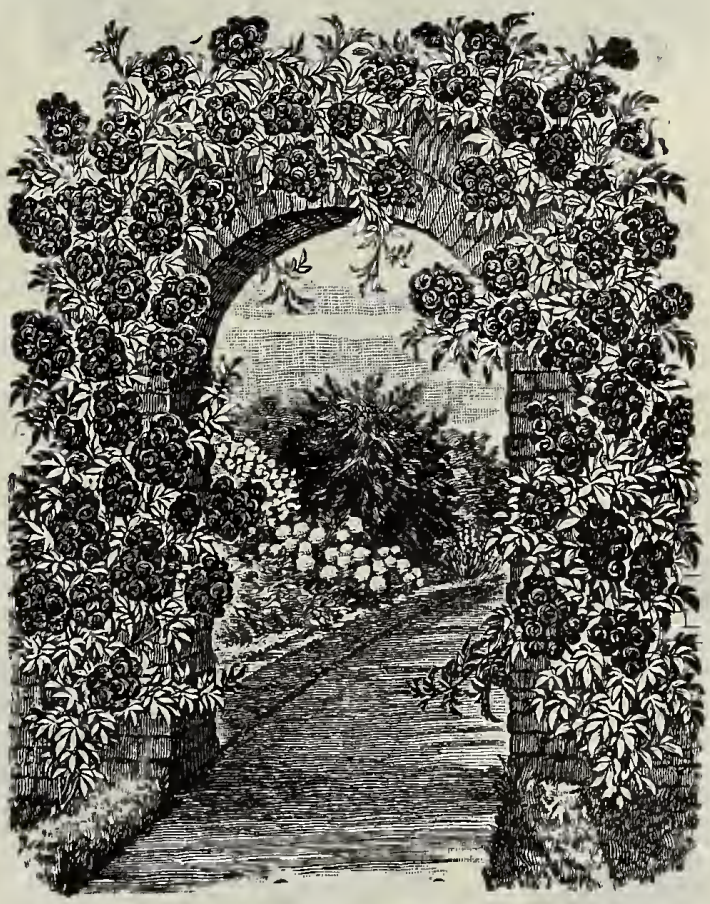

Crimson Rambler

Queen of the Prairie-Bright rose color; large and double; very vigorous; and rapid in its growth; the best climbing rose. 20 cents each.

\section{A BLUE ROSE}

\section{The Greatest Rose Novelty of the Century}

The New Rambler, (Violet Blue), hailed by the German rose growers as the forerunner of a genuinely cornflower blue rose, is a seedling of Crimson Rambler, very vigorous and hardy, and free blooming. 50 cents each. 


\section{Memorial Rose}

A rose of trailing habit, a very hardy and rapid grower, with a glossy green foliage, which remains on until late in the fall. Its flowers are pure white and very fragrant. It is especially

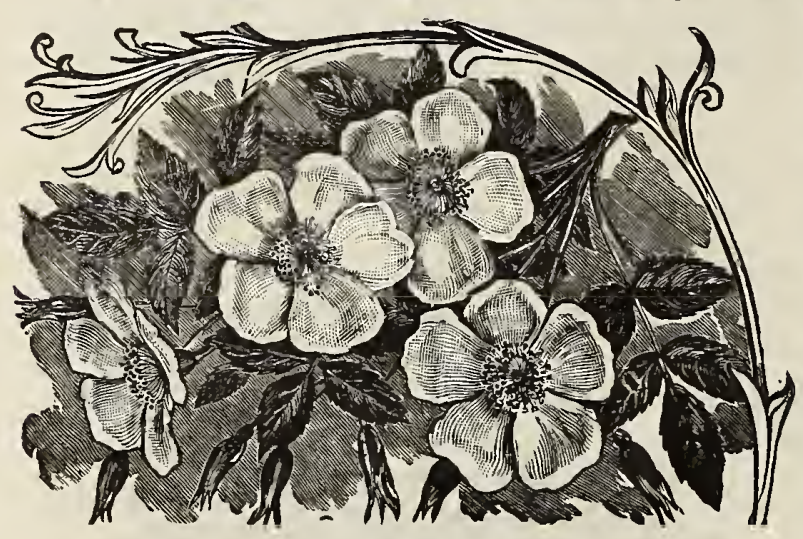

Memorirl Rose adapted to cemetery planting, hence its name; or it may be trained as a screen to hide some unsightly root, stump or rock. 20 cents each.

\section{Monthly Blooming Roses}

Marshal P. Wilder-Color bright cherry carmine, fragrant, of vigorous growth, with fine foliage, one of the freest of the hybrid perpetuals to bloom, we can recommend this rose without hesitation. 25 cents each, five for $\$ 1.00$.

Paul Neyron-Deep rose color, splendid foliage and habit, with large flower. 25 cents each, five for $\$ 1.00$.

Ulrich Brunner-The flowers are very large, of beautiful form and very double, color deep rich rose. 25 cents each, five for $\$ 1.00$.

Anne de Diesbach-Carmine, beautiful shade, moderately full and very large. 25 cents each, five for $\$ 1.00$.

Madame Plantier-One on the finest pure white roses, blooming in clusters, 20 cents each six for $\$ 1.00$.

Persian Yellow-Deep golden yellow; double and very fine. 30 cents each.

Coquette des Blanches-Pure white, flowering in clusters, very free bloomer. 25 cents each, five for $\$ 1.00$.

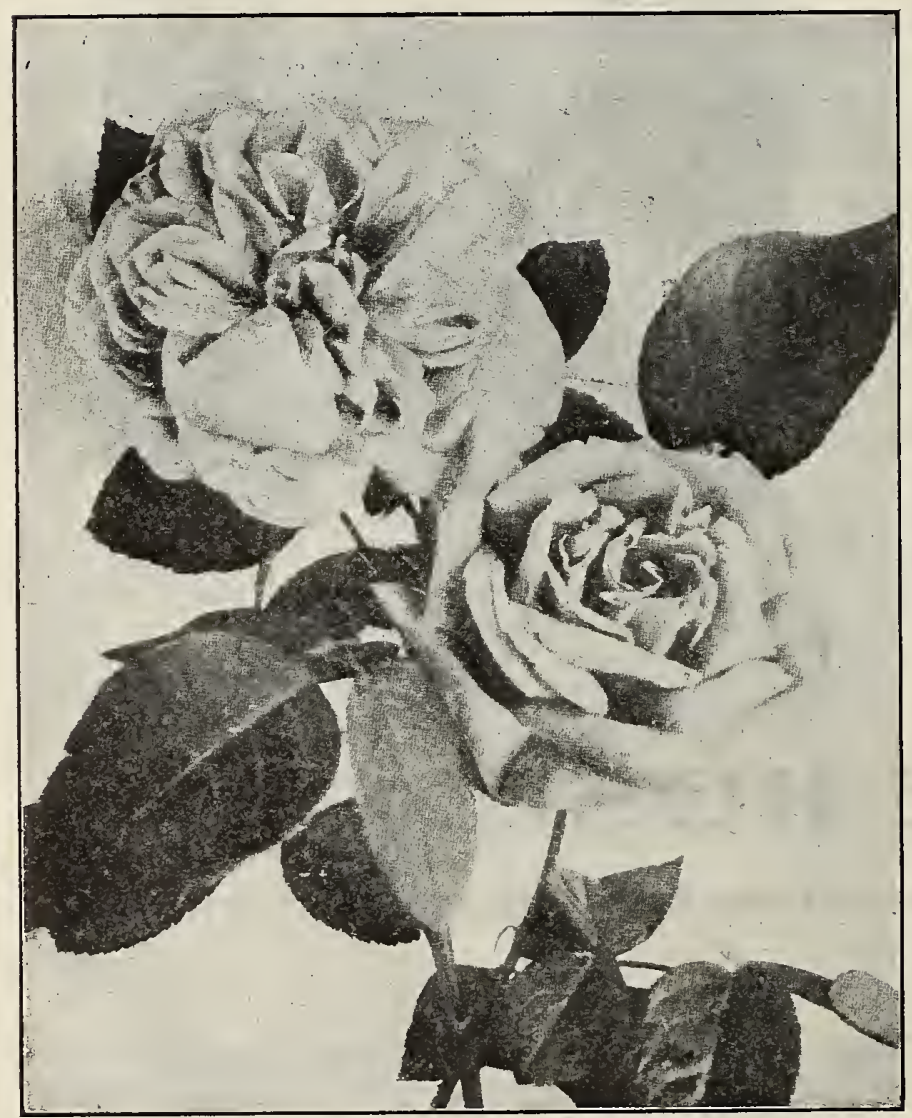

General Washington-Brilliant rose crimson, large, double fine. 20 cents each, five for $\$ 1.00$.

General JacqueminotBrilliant crimson scarlet, very showy and effective. 20 cents each, five for $\$ 1.00$.

Madam Chas. Wood-One of the most beautiful hybrid perpetual roses ever introduced. The flower is extra large, full and double, color deep rose crimson, sometimes brilliant scarlet with maroon shading, it blooms soon after planting out and continues to bloom all summer. 20 cents each, five for $\$ 1.00$.

American Beauty-One of the best and most $v$ al u a ble roses, both for $\mathrm{gard}$ en and house culture. Color ros y crimson, exquisitely shaded and very handsome. Extra large full flowers and fine bud. The plant is very hardy and a constant bloomer. Each s hoot produces a bud. The fragrance is delightful. Vigorous growth and has the everblooming qualities of the Tea Rose. Each 35 cents, three for $\$ 1.00$. 
Frau Karl Druschki-Or White American Beauty-A pure paper white, free flowering, large sized Hybrid Perpetual. It is a remarkably handsome plant with bright heavy foliage and strong, upright growth. The bloom is perfect in form on fine, long stems, and of the purest possible white. There is nothing in the line of perfectly hardy roses that can compare with this one in form, color, and general finish. 2-year field grown. 35 cents each, three for $\$ 1.00$.

\section{Moss Roses}

The Moss Rose is as hardy as any rose can be, and an extra vigorous grower. They are much admired on account of their bright, healthy foliage and mossy-like covering of the buds. While they bloom but once a year, the flowers are large, beautiful and plentiful.

Capt. John Ingram-Dark, velvety purple, full and fine. 25 cents.

Glory of Mosses-Pale rose, very large, full and beautiful. 25 cents each.

Perpetual White-Pure white. It blooms in large clusters. 25 cents each.

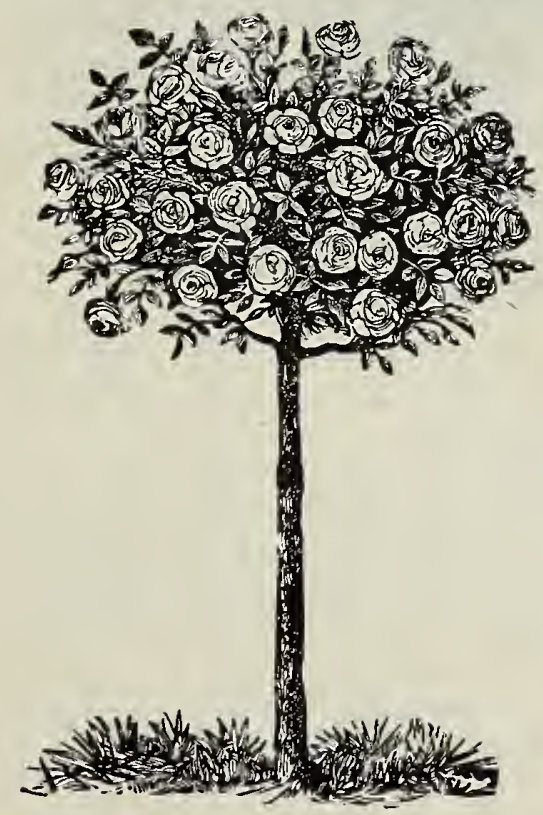

Tree Rose

"Baby Rambler"-A dwarf (bush not climbing) form of Crimson Rambler, and furthermore, ever-blooming. Will bloom continuously throughout the summer if planted out doors. Has the same bright crimson color as the Climbing Rambler, and blooms in clusters of 10 to 40 flowers at one time on plants of fair size. "Baby Rambler" is one of the best red roses for bedding, and is going to be just as popular and as extensively planted as the climbing form has been. Can be grown in pots. 2-year plants, 35 cents each.

White "Baby Rambler"-Same as above, except color, which is pure white. 35 cents each; 3 for $\$ 1.00$.

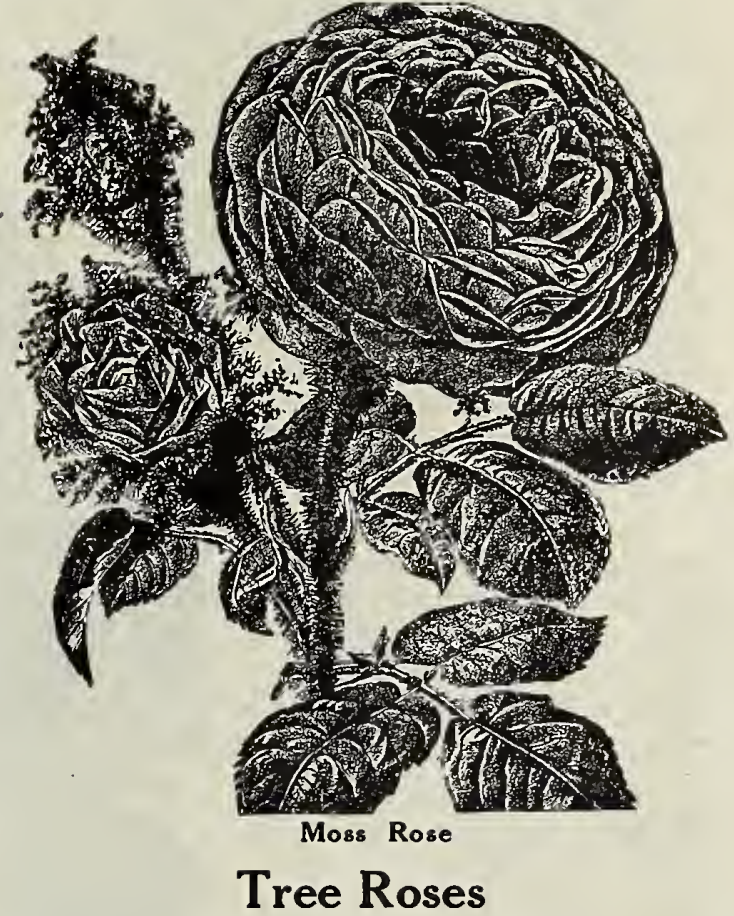

These are grafted on hardy rose stalks 4 to 5 feet high, are tree shaped and when in full bloom are objects of beauty, making handsome plants for the lawn, or as border plants along the side-walk and driveway. They are coming into popular favor and at the low price we are offering them this year anyone can set out a few of these pretty tree roses in his yard or on the lawn.

Crimson Rambler Tree Rose-No other rose is so well adapted for growing in tree form. The branches droop gracefully and reach nearly down to the ground, thus forming a regular weeping tree. 75 cents each.

Hybrid Perpetual Tree Rose-These hardy and free blooming roses we have in tree form and can furnish the following colors: Red, White and Yellow. 75 cents each; 10 for $\$ 6.50$.

Baby Rambler Tree Rose-A most attractive novelty in hardy roses. Budded on strong, straight stems 4 feet high; the round, bushy, Baby $R$ ambler tops at all times a perfect mass of crimson bloom. The most florescent and striking of all tree roses. $\$ 1.00$ each. 


\section{Weeping Trees}

These trees form objects of great beauty when planted as single specimens on lawns, in the front yard and especially when used for cemetery decorations. Also of great value for covering arbors. Our list embraces the best varieties.

Tea's Weeping Mulberry-We cordially recommend this as one of the thriftiest, hardiest and most beautiful of weeping trees. It transplants easily and is appropriate for both large and small places. The leaves are lustrous, distinctly lobed, the branches slender and willowy, forming a tall, narrow green tent of dense shade. Fine trees, $\$ 1.00$ each.

Catalpa Bunglii or Umbrella Plant-One of the finest ornamental trees we have; 'it is perfectly hardy; you will be pleased with this tree on your lawn. Trees grafted, 7 feet high, 75 cents each.

Weeping Birch-Cut leaved. Probably the most popular and most desirable lawn tree in existence, and produces a beautiful effect on streets and avenues. Makes a vigorous growth and is perfectly hardy. Trunk straight, slender, white as snow; the slim side branches drooping in a most picturesque manner; foliage deli-

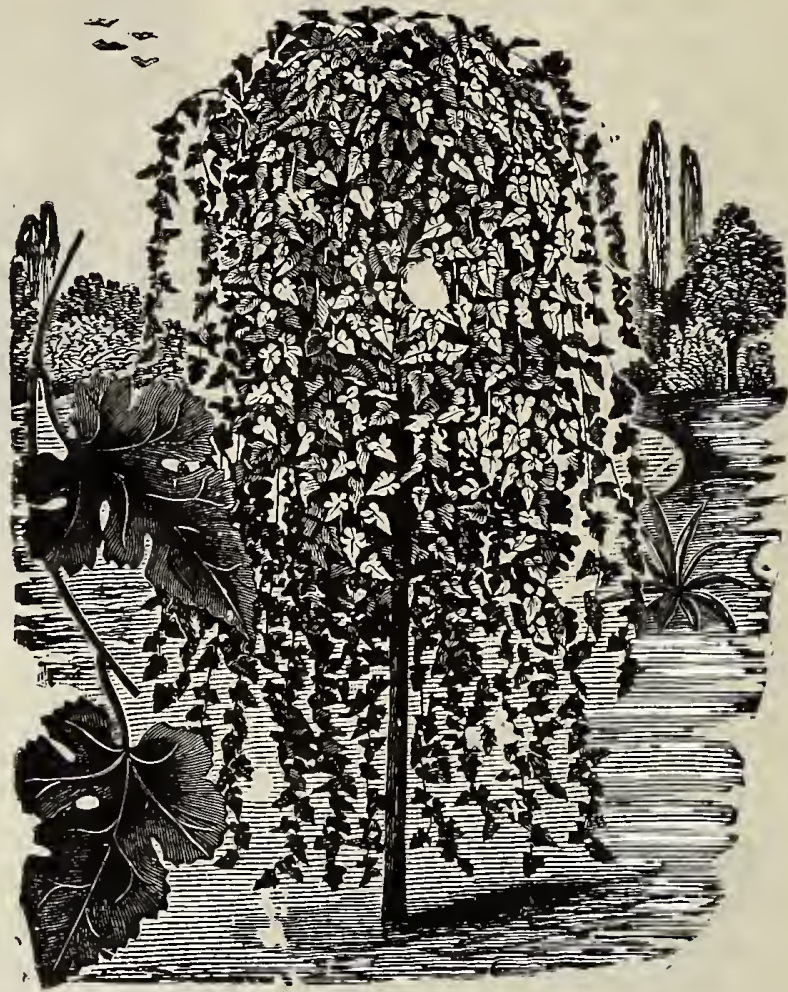
cate and deep cut, coloring finely in the fall. The drooping branches and silvery bark form a most effective combination during the winter months. $\$ 1.00$ each.

Camperdown Weeping EIm-Its vigorous branches, which have a uniform habit, overlap so regularly that a compact roof-like head is formed. Leaves are large, glossy dark green. A strong, vigorous grower. One of the best weeping trees. It can be trained to form an arbor if desired. The peculiar characteristics of this tree make it very popular and valuable for the lawn. Hardy. $\$ 1.00$ each.

Mountain Ash-( Weeping)-A beautiful tree, with straggling, weeping branches; makes a fine tree for the lawn, suitable for covering arbors. $\$ 1.00$ each.

Kilmarnock Weeping Willow-An exceedingly graceful tree with large glossy leaves; one of the finest of this class of trees; very hardy. 50 cents each.

Wisconsin Weeplng Willow-Of drooping habit, and said to be perfectly hardy in the northwest. 4-foot trees, 20 cents each; 5 -foot trees, 25 cents each. 


\section{Russian Mulberry}

This tree has been planted very extensively in the Western states for the past fifteen years, and we know of no other tree that will stand as much drouth and neglect and yet make a good growth each year.

It makes a very good shade tree, holding its leaves late into the fall; and for a hedge, without thorns, it has no superior.

Trees commence to bear at two years old; fruit resembles the blackberry, and will ripen from July 1st to September.

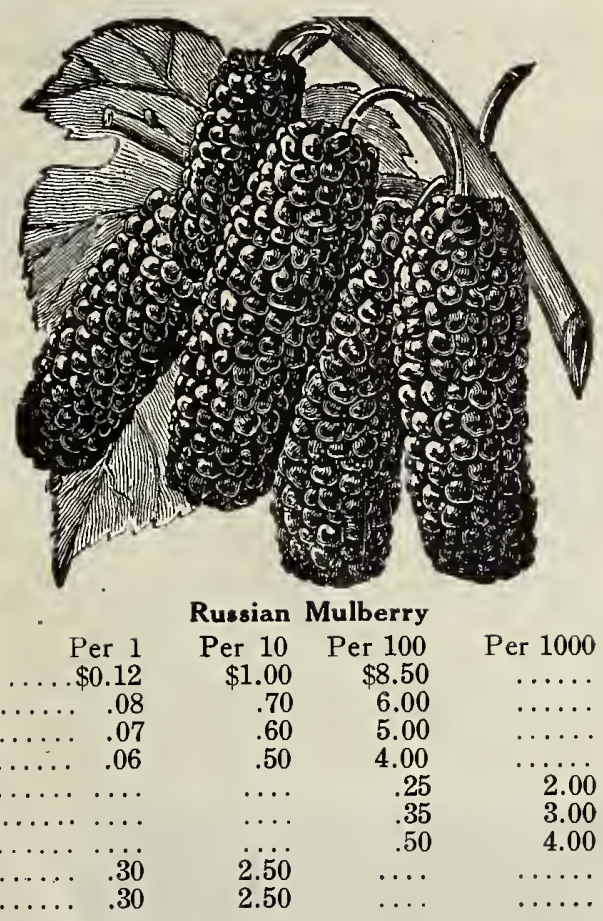

5 to 6 feet, well branched, transplanted ........... Per 1

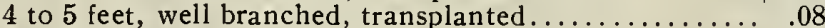

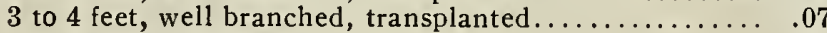

2 to 3 feet, branched, transplanted....................

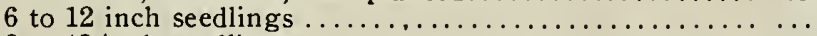

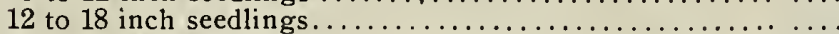

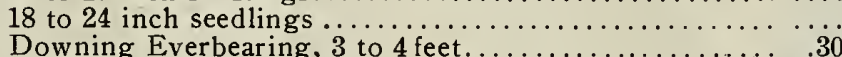

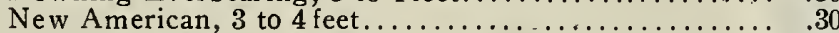

ussian Mulberry

$\begin{array}{rrr}\$ 1.00 & \$ 8.50 & \ldots \ldots \\ .70 & 6.00 & \ldots \ldots \\ .60 & 5.00 & \ldots \ldots \\ .50 & 4.00 & \ldots . . \\ \ldots \ldots & .25 & 2.00 \\ \ldots . & .35 & 3.00 \\ \ldots .50 & .50 & 4.00 \\ 2.50 & \ldots . & \ldots \ldots \\ 2.50 & \ldots . & \ldots \ldots\end{array}$

\section{Seeds}

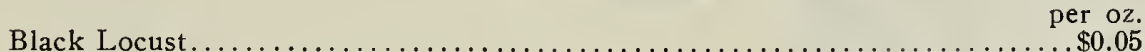

Per lb. $\$ 0.05 \$ \$ 0.40$

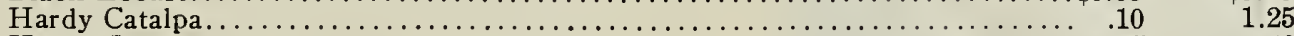

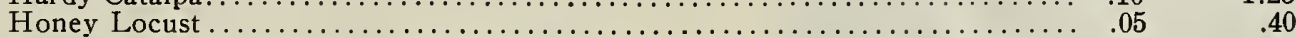

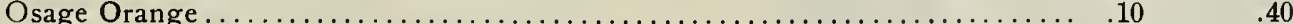

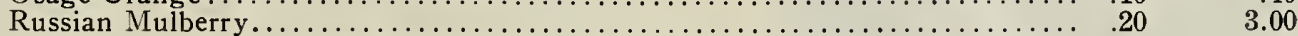

If you want seeds sent by mail, add 8 cents per pound to price.

\section{Apple Grafts}

Send in your orders early. The first of March we commence to plant and after that date our list of varieties is broken.

No. 1 Piece Root . . . . . .

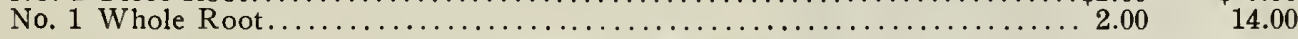

\section{Nut Trees}

Sweet Chestnut, 12 to 18 inch................... Per

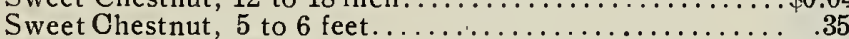

Sweet Chestnut, 4 to 5 feet......................30

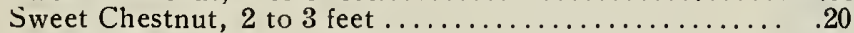

Spanish Chestnut, 12 to 18 inch $\ldots \ldots \ldots \ldots \ldots \ldots \ldots \ldots \ldots .08$

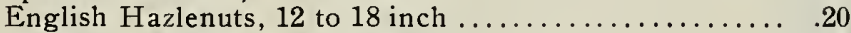

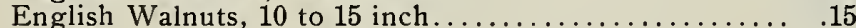

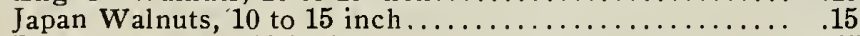

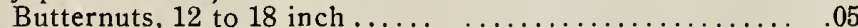

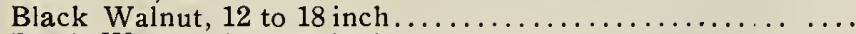

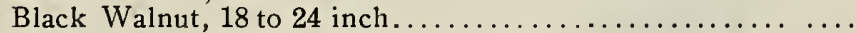

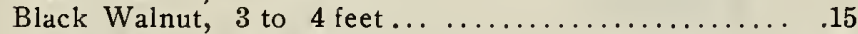

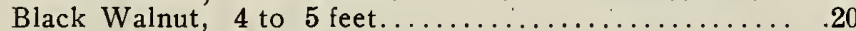

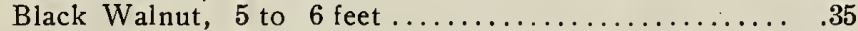

\begin{tabular}{|c|c|c|}
\hline $\begin{array}{c}\text { Per } 10 \\
\$ 0.30\end{array}$ & Per 100 & Per 1000 \\
\hline 3.00 & $\ldots$ & \\
\hline 2.50 & $\ldots$ & \\
\hline 1.50 & $\ldots$ & \\
\hline .70 & $\ldots$ & \\
\hline 1.50 & $\ldots$ & $\therefore$ \\
\hline 1.25 & $\ldots$ & \\
\hline$i .25$ & & \\
\hline .45 & 4.00 & \\
\hline .... & .80 & \\
\hline & 1.00 & \\
\hline $\begin{array}{l}1.10 \\
1.75\end{array}$ & $\cdots$ & \\
\hline 3.00 & & \\
\hline
\end{tabular}

\section{Sudden Sawlog}

Or Norway Poplar-A very promising tree but lately introduced and received its name from its very rapid growth. It resembles the Carolina Poplar, but makes a larger growth, both in height and thickness of limb.

Price-4-foot tree, 20 cents; 5 -foot, 25 cents; 6 -foot, 30 cents; 7 -foot, 35 cents; 8 -foot 40 cents, and 10 -foot, 50 cents each. 


\section{Evergreens---Transplanted}

Scotch and Austrian Pine, 2 to 3 feet............................. $\$ 0.35$

Per 10

Scotch and Austrian Pine, 18 to 24 inches............................. .30

$\$ 2.50$

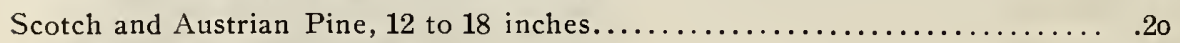

2.00

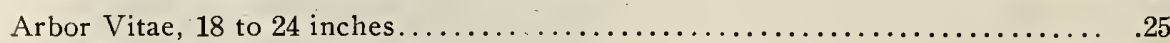

1.50

2.50

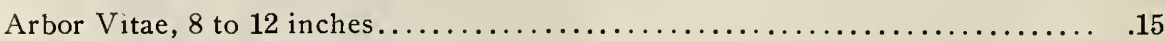

1.00

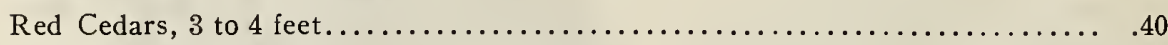

3.50

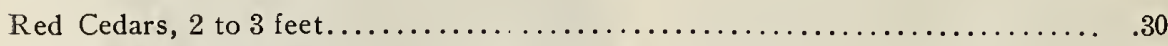

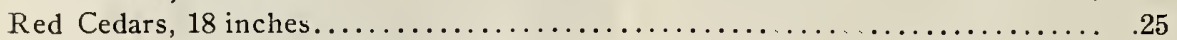

1.00

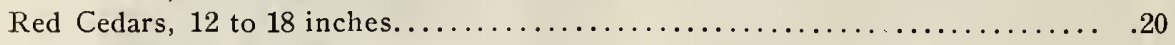

1.60

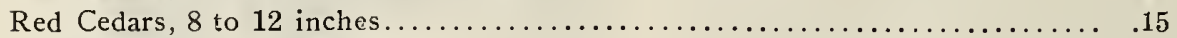

1.20

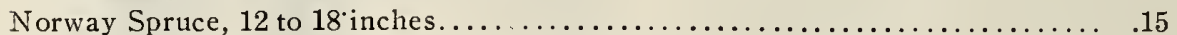

I. 00

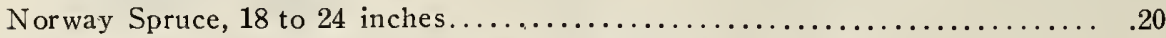

1.50

Black Hills Spruce, taken up with earth, 12 inches................... .30

2.50

Black Hills Spruce, taken up with earth, 18 inches................. .50

3.50

Blue Spruce, taken up with earth, 12 inches.......................... .35

Blue Spruce, taken up with earth, select color...................... .50

Blue Spruce, taken up with earth, select color ...................... .75

...

$\cdots$

$\ldots$

Irish Juniper, taken up with earth,

12 inches......................35

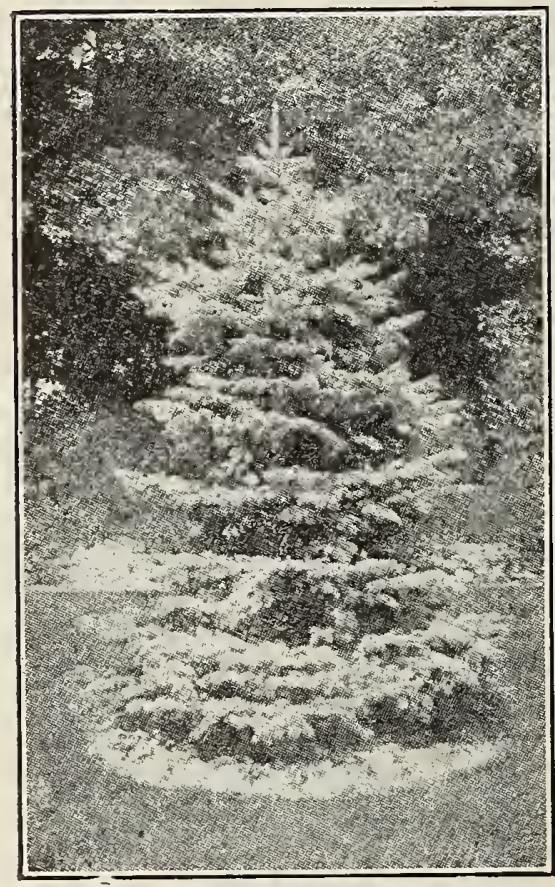

Blue Spruce

Irish Juniper, taken up with earth,

18 inches..................... 75

Jack Pine, 2 feet................ . 30

2.50

Austrian, Scotch and White Pine, Douglas Spruce White Spruce, or Balsam Fir, any of these, 12 inches in height. with earth, each 30 cents.

\section{Evergreen Seedlings}

Below we give prices on seedlings such as we use for our own plantings; they require a great deal of care for the first year after transplanting, but when once started will soon make fine trees.

Seedling evergreens are grown in the north and cannot be shipped until after April 15th.

Per 10 Per 100 Per 1000

Scotch and Austrian Pines,

10 to 12 inches.......... $\$ 0.35 \quad \$ 3.00 \quad \$ 20.00$

White Pine and Arbor

Vitae, 8 to 10 inches.... $.45 \quad 4.00 \quad 30.00$

Norway and White Spruce,

10 to 12 inches........... $.35 \quad 3.00 \quad 20.00$

Jack Pine, 10 to 12 inches. . $\quad .35 \quad 3.00 \quad 18.00$

Red Cedar, 5 to 7 inches. . $\quad .60 \quad 5.00 \quad \ldots \ldots$

Red Cedar, 6 to 9 inches.. $.85 \quad 7.00 \quad \ldots .$.

\section{Phlox}

No class of hardy plants is more desirable than the Perennial Phloxes. They will thrive in any position and can be used to advantage in the hardy border, in large groups on the lawn, or planted in front of belts of shrubbery where, by judicious pinching back and removing faded flowers, a constant succession of bloom may be had until frost.

Mixed colors, Red, White, Pink and Lavender, 15 cents each, 8 for $\$ 1.00$. 


\section{Shade Trees}

Ash, Soft Maple, Box Elder, Black Locust and Carolina Poplar-

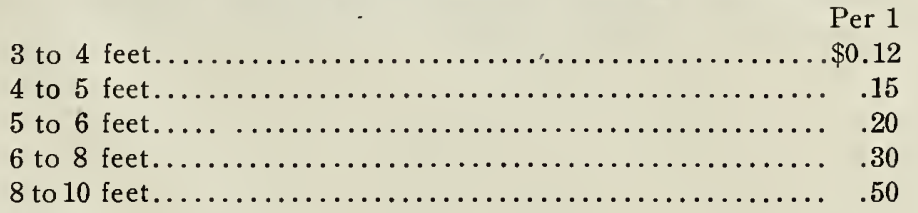

Elm and Sycamore-

4.50

40.00

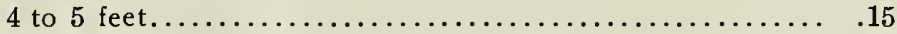

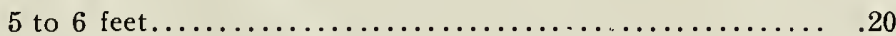

6 to 8 feet........................................ 30

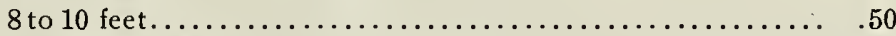

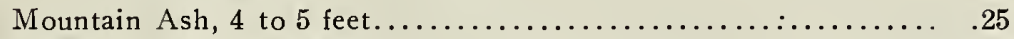

Mountain Ash, 5 to 6 feet................................ . 30

Hard Maple, 5 to 6 feet................................... .35

Hard Maple, 6 to 8 feet................................. .50

Horse Chestnut, 5 to 6 feet........................... .50

Russian Olive, 4 to 5 feet.............................. 40

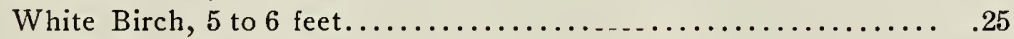

White Birch, 4 to 5 feet...................................

Honey Locust, 3 to 4 feet............................... .

Honey Locust, 4 to 5 feet.............................

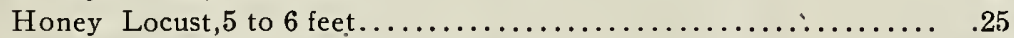

Honey Locust, 6 to 8 feet.............................. $\quad .40$

Thornless Honey Locust, 3 to 4 feet........................ .20

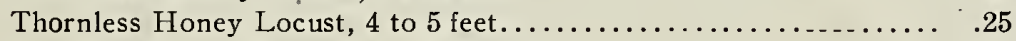

Thornless Honey Locust, 5 to 6 feet..........................35

Thornless Honey Locust, 6 to 8 feet........................... .45

Balm of Gilead, 5 to 6 feet................................

Wild Black Cherry, 5 to 6 feet............................ .25

Tulip Poplar, 5 to 6 feet................................ $\quad .35$

American Linden, 5 to 6 feet............................. .25

Norway Maple, 5 to 6 feet...............................65

\section{Hedge Plants}

Privet, 6 to 12 inches.

Privet, 12 to 18 inches..........................................

Privet, 18 to 24 inches................................... .40 $3.00 \quad 25.00$

Osage, strong plants.......................................... $\quad .35 \quad 3.00$

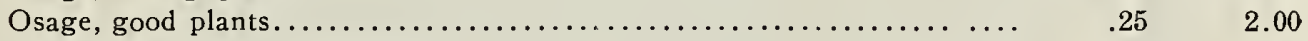

Russian Mulberry, 6 to 12 inches.................................. $\quad .25$

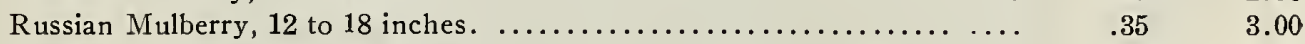

Russian Mulberry, 18 to 24 inches........................... $.50 \quad 4.00$

\section{Cuttings}

Cottonwood and Carolina Poplar

Per 100 Per 1000 ... $\$ 0.20 \$ 1.50$

Wisconsin Weeping Willow....................................... 25

Silver Poplar................................................. .20 1.50

White and Yellow Willow.......................................... .20 1.50

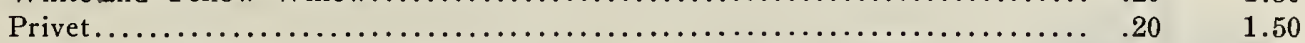

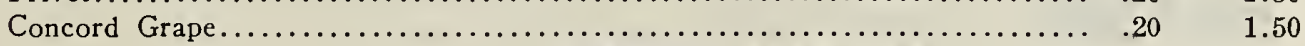




\section{Forest Tree Seedlings}

We have millions of them, principally Black and Honey Locust, Catalpa and Mulberry. Lumber and posts are becoming more expensive every year, and people could save a great deal of this expense by planting some of the quick-growing forest trees. Nearly every farm has some waste land that could be used for this purpose.

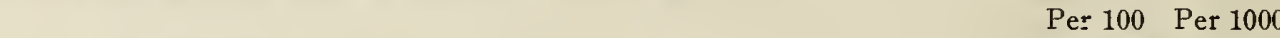

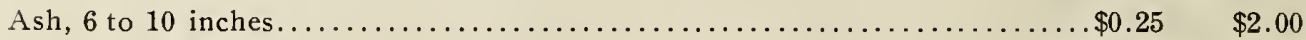

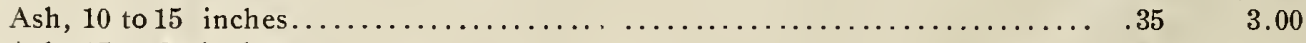

Ash, 15 to 30 inches.................................. .50 4.50

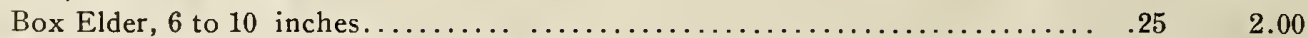

Box Elder, 10 to 15 inches................................... $35 \quad 3.00$

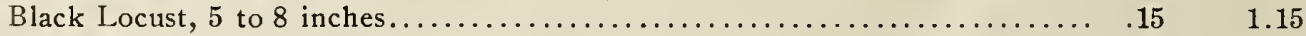

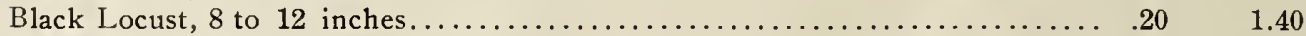

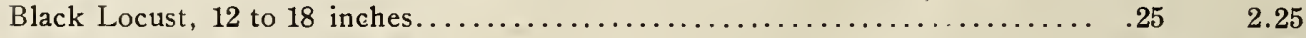

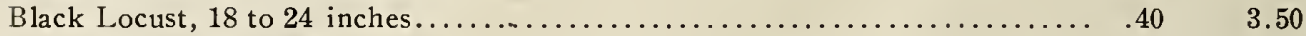

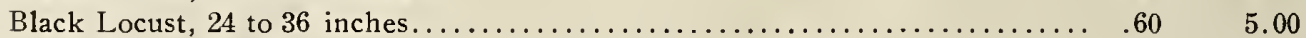

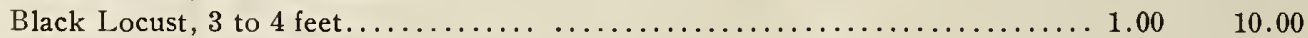

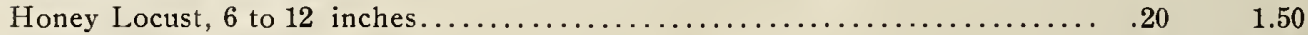

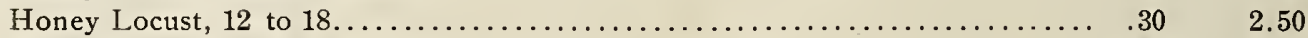

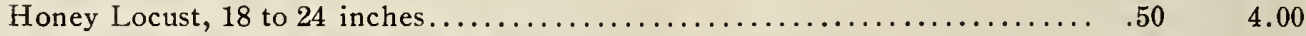

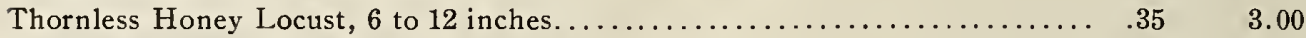

Thornless Honey Locust, 12 to 18 inches......................... $.45 \quad 4.00$

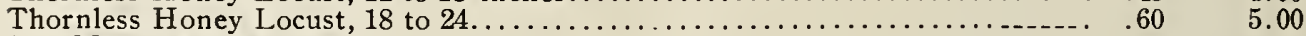

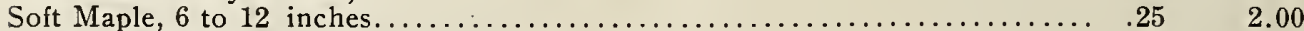

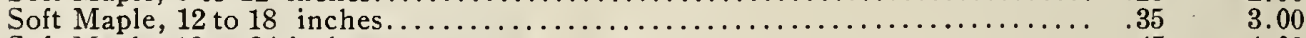

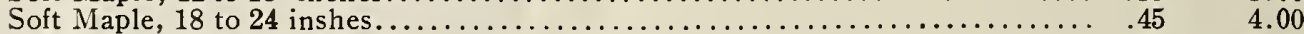

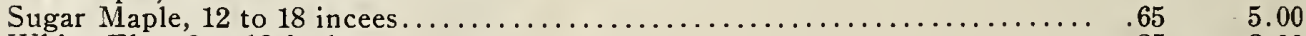

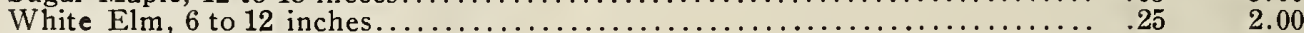

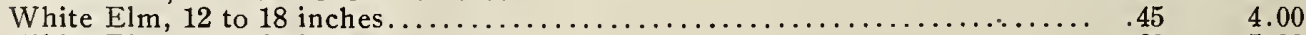

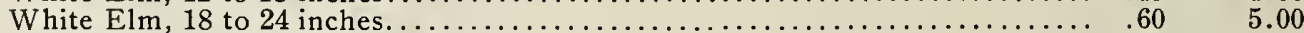

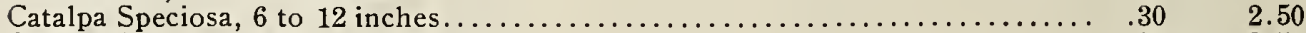

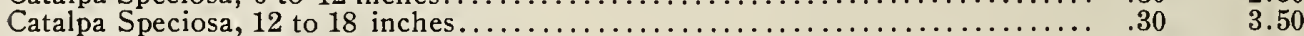

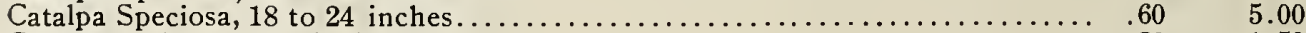

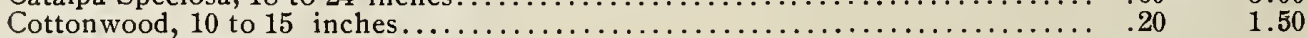

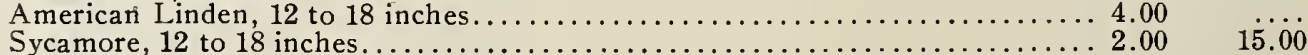

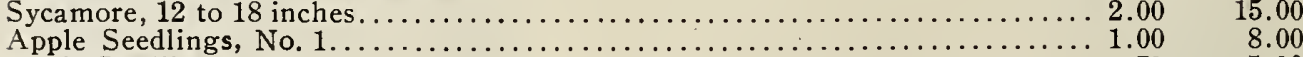

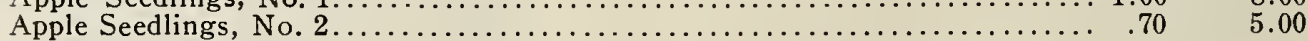

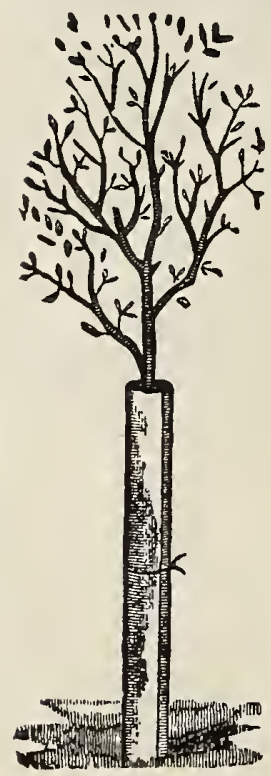

\section{Tree Protectors}

\section{Price -- 2 cents each; $\$ 1.50$ per 100}

Same are made of veneer and are the best and easiest applied of anything ever used. Two men can wrap 1,000 trees a day. They are 18 to 24 inches long, 9 to 12 inches wide and one-twelfth inch thick, and are fastened with small wire around the center, and will last from three to five years.

Will protect your trees from rabbits, mice and borers; will also protect the stems from sun-scald, and can be left on during the summer and will not injure the tree. They are furnished green, tied in bundles of 100 each and are ready for use. 


\section{Seed Potatoes}

We are now prepared to furnish our customers with first-class seed potatoes and would be pleased to receive a trial order from you.

Extra Early Ohio-(Red River Grown)-This is without doubt the most popular early potato in the country. We have more calls for it than any other early. Every one knows what it is and knows that it can be relied upon for an early market variety in almost every locality. They are smooth, clean and free from prongs and scab. They grow stronger and more vigorous, maturing the crop in shorter time and yielding much more than home seed, so that there is the utmost satisfaction in planting them. Potato growers in the South will have their crop ready for the market from ten days to two weeks earlier, if our Red River Valley Ohios are planted. This variety is sometimes sold under the name of Early Six Weeks Potato. It will pay to change your seed this year and plant a few acres of our selected stock of Ohios. Price, 3 pounds 50 cents, postpaid; peck 50 cents; bushel $\$ 1.75$.

Rural New Yorker-A medium late variety which grows very large. A good variety to produce large crops and of excellent quality. 3 pounds 50 cents, postpaid; peck 50 cents; bushel $\$ 1.75$.

\section{Stowell's Evergreen Sweet Corn}

Price, per quart, 15 cents; peck, 75 cents; bushel, $\$ 2.75$.

\section{Sweet Potato Seed}

We can also furnish Jersey Sweet Potato for seed of first-class quality at 5 cents per pound. It is best not to have them shipped until you are ready to plant, as they will not stand misuse at all. For shipments longer than 100 miles they should be sent by express.

On Potatoes, Sweet Potatoes and Corn the customer pays the freight or express. Potatoes take a low freight rate and express rate is 20 percent lower than merchandise rate.

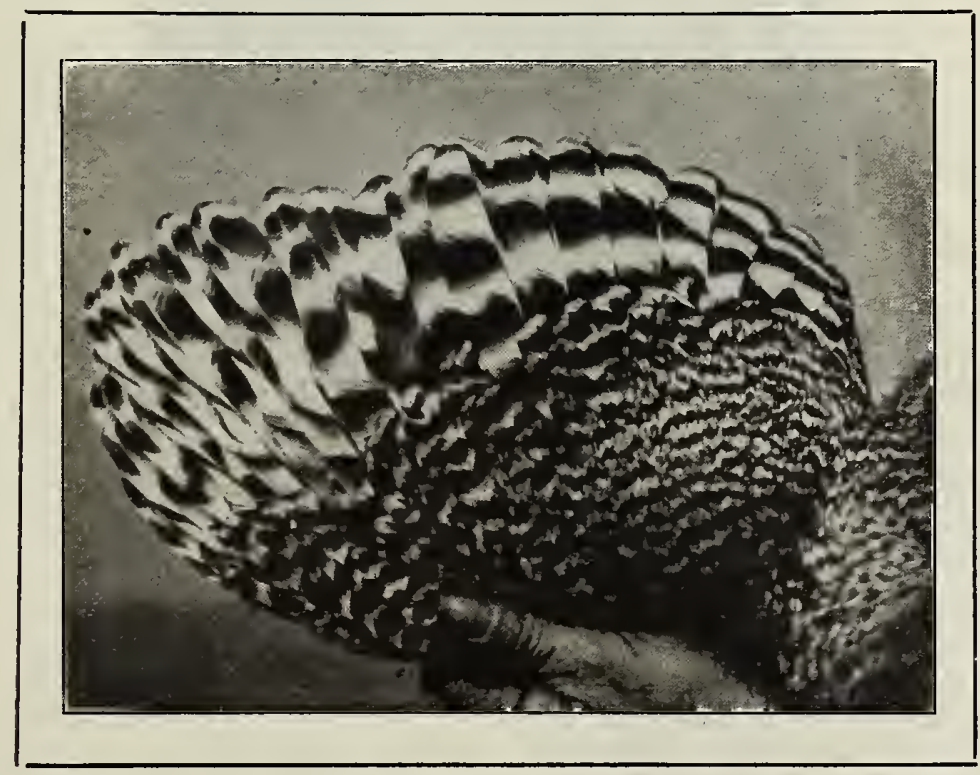

The above cut was made from the photo of the w ng of a cock-bird that took second premium two years in succession 1907 and 1908 at Lincoln, Neb. 


\section{Barred Plymouth Rocks}

We have been breeding and showing Barred Plymouth Rocks for the last ten years, not so much for the money there is in it for us, (they are very profitable,) but because they are a popular variety, hard to breed to the Standard of Perfection, and there is always such hot competition in this variety at our large shows, that the breeder who can win a few first or second premiums, has won something he may well be proud of.

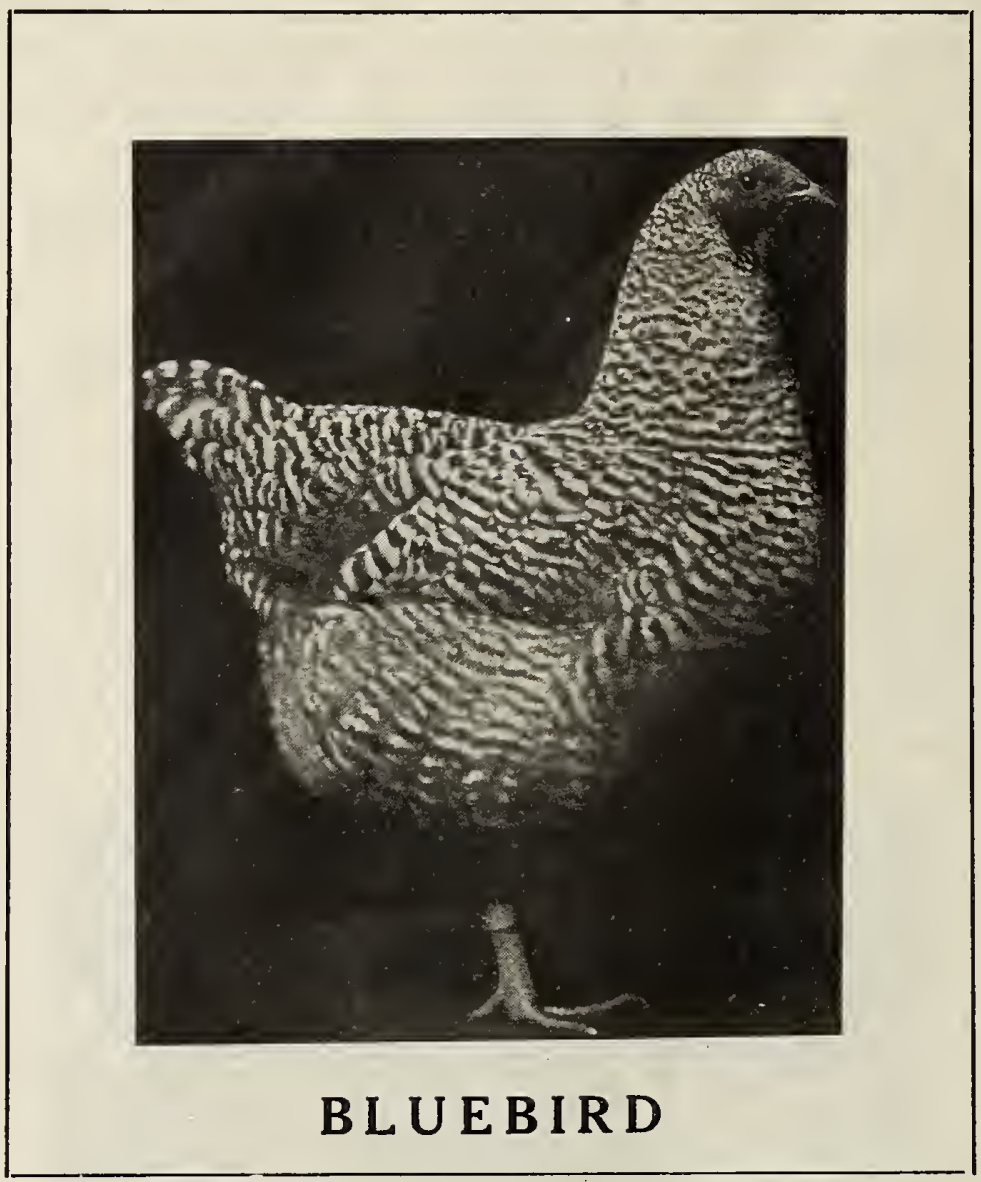

The above cut was made from a photo of Bluebird, the first premium pullet at Nebraska State Show, Lincoln, 1908, score 93 by Russell. As a hen she took first premium at Nebraska State Show at Hastings last winter.

\section{Matings}

We practice the double mating system; the standard requires that the male and female Barred Rock shall be of the same color, and this color can not be obtained by single mating, for this reason we mate exhibition colored females with very light even barred males to secure good colored pullets, and exhibition colored males with very dark even barred females to secure good colored cockerels.

\section{Prices}

Eggs, $\$ 3.00$ per 15 . In ordering please state whether you want to raise good cockerels or good pullets, or both, we will then know how to fill your order. 


\section{Plant Department}

One year ago we added to our nursery plant two greenhouses and this year we erected another one. We can now furnish our customers with house plants and plants for bedding in open ground in the spring.

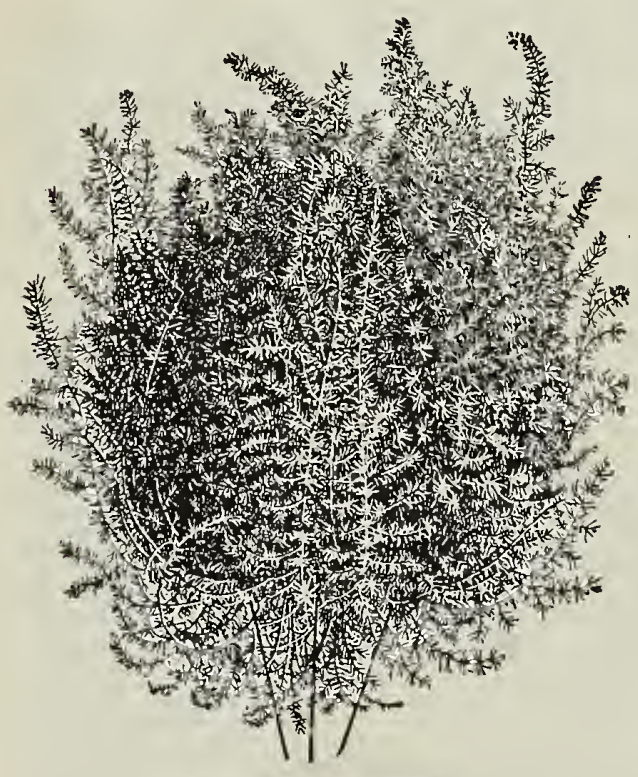

Asparagus Sprengeri

Asparagus Plumosus or Asparagus Fern-It is a most elegant plant with smooth stems and has very graceful, arching, filmy foliage; it rivals the delicate beauty of the Maiden Hair Fern. The cut sprays of this variety endure for a long time. $\mathrm{It}$ is indispensible as a green in floral decorations. Remarkably fine for pot culture as it is veryornamental. By mail 10 cents each, by express, large plants, 20 cents and up.

Asparagus Sprengeri-One of the best known plants introduced in years. This plant is exceedingly useful and ornamental, as a pot plant. In a hanging basket it droops gracefully with branches that are sometimes 4 to 5 feet in length; of a rich shade of green. The fronds retain their freshness for weeks after being cut. Especially useful for planting in ferneries or in suspended baskets. It is fine for house decorations as it withstands dry atmosphere. By mail 10 cents each, by express, large plants, 20 cents and up.

extensively used as edging for beds and also for massing.

Ageratum-A very popular bedding plant,

Stella Gurney-A great aquisition and decidedly the best blue up to date, a continuous and profuse bloomer. Very effective in a bed by itself, and also makes an attractive border for beds of taller growing plants. 7 cents each; 75 cents per dozen by express.

Rex Begonias-Well known as very decorative plants for the house. They do not require sun or even strong light and so can be used where other flowers or plants will not thrive. They should be given a nice, shady situation, and then soil should be light and porous, composed of rich loam, sand and leaf mold. The Rex varieties are very éffective as pot plants. Care should be taken to keep the foliage free from dust. Ocassionally the plants may be showered, but should not be exposed to the sun until the leaves are perfectly dry. We have 5 of the best varieties. 20 cents each; larger plants by express from 25 cents up.

Caladium Esculentum-(Elephant's Ear)-For obtaining tropical effects in lawns and garden planting this beautiful plant takes a prominent place. Should have plenty of water and good rich soil. When at its best, stands six to seven feet high, with bright green leaves three to four feet long and two and one-half feet wide. Large bulbs 20 cents each; 6 for $\$ 1.00$.

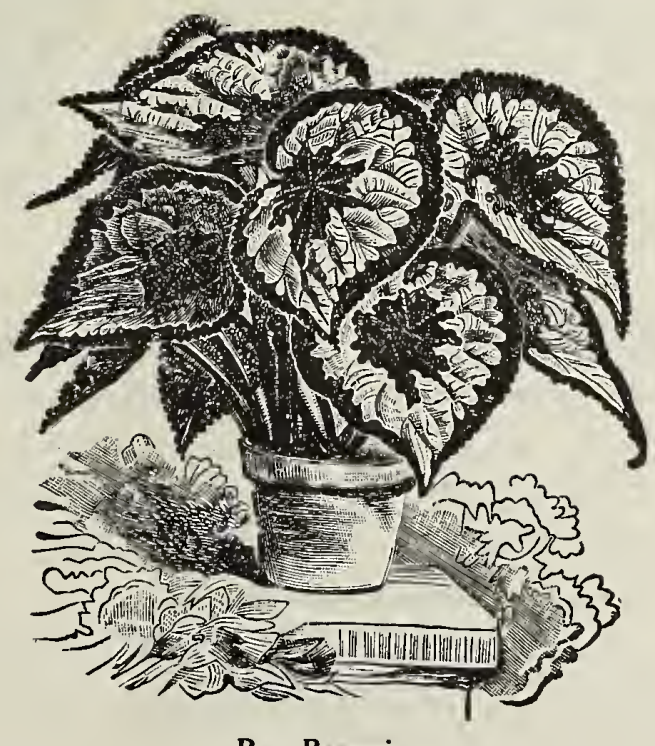

Rex Begonia 


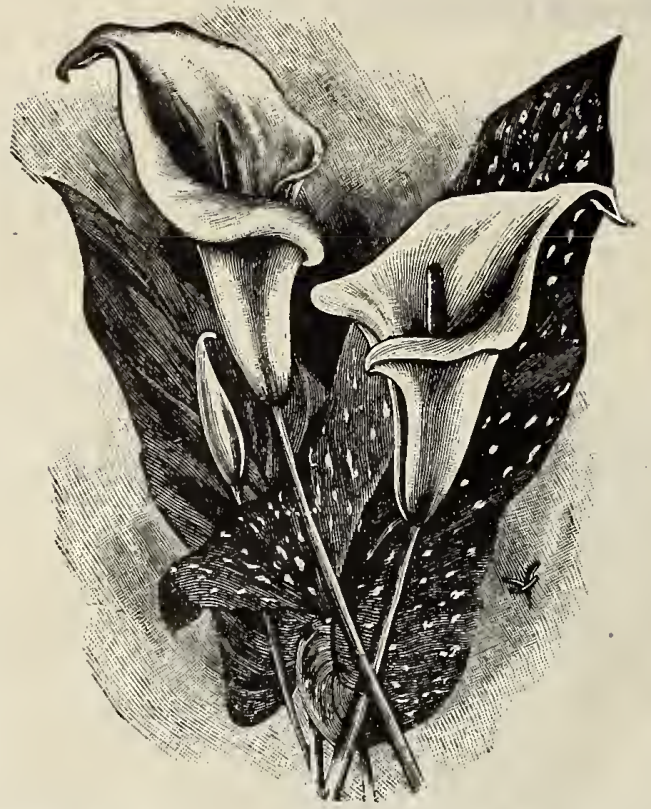

\section{Callas}

One of the most satisfactory summer flowering bulbs when planted in open ground, and equally good as a pot plant for winter blooming, when planted in the fall, the foliage is a dark green, flowers pure while. Large bulbs 20 cents each; 6 for $\$ 1.00$.

\section{Cannas}

One of the most popular of bedding plants with their green and bronze foliage and bright flowers; we grow six of the best varieties. 10 cents each; one dozen $\$ 1.00$; for dry bulbs, bulbs which have been started to grow in the green house, 15 cents each; 8 for $\$ 1.00$.

King Humbert -4 to 5 feet. Giant flowered, orange scarlet, bronze leaf. The flowers are very large and very free blooming. The handsome leathery foliage is of strong habit.

Florence Vaughan-5 feet. Green foliage; flowers are a rich golden yellow, thickly dotted brighest red.

Mad. Crozy $-3 \frac{1}{2}$ feet. Green foliage. Flowers vermillion with gold border.

Burbank -5 feet. Green foliage; flowers are very large in size; a rich canary-yellow with crimson spots.

Crimson Bedder-Bright crimson scarlet.

Alsace-Pure white, folage green.

\section{Carnations}

The Carnation is the most popular flower grown by florists, as they are much desired for house decoration and personal adornment. The new mammoth varieties are especially attractive. They are beautiful in coloring, perfect in form and shape, and some of them $3 \frac{1}{2}$ inches across. We will list the following varieties as best for house culture. Plant in open ground n May. 15 cents each; 6 for 50 cents. Large plants by express in September and October for winter blooming. 25 cents each; 5 for $\$ 1.00$.

Enchantress-One of the grandest Carnations of any color; an exquisitely delicate shade of shell-pink, deepening towards the center. Blooms early and continuously.

Harlowarden-The largest and best of its color, a bright dazzling crimson. Flowers often measure three inches in diameter, and are well supported on long stiff stems. A wonderfully free bloomer, always full of buds.

Rose Pink Enchantress-A lovely rose pink shade of color put on by the old favorite "Enchantress." The parent's practical, wide-awake habit of growth and trustworthy blooming

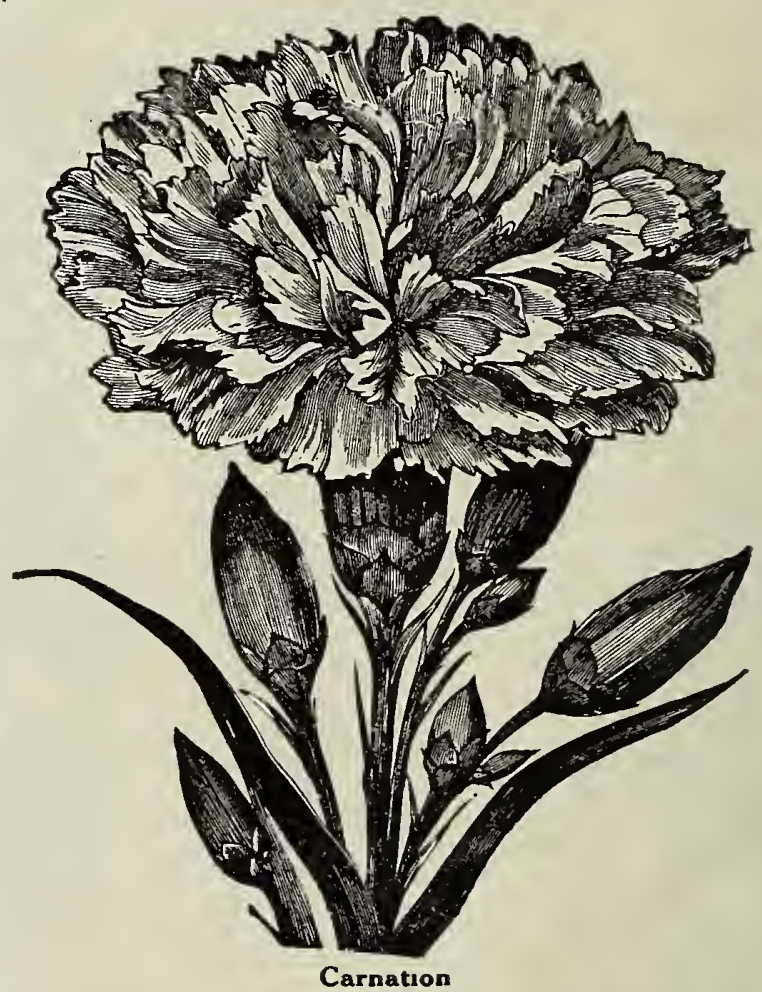

Carnation qualities have always made it popular, and this new coloring but adds greatly to an already firstclass reputation. 
The Beacon-A splendid new red that blooms throughout a long season. Flowers are gracefully formed, and will average from two and three-quarters to three inches in diameter. Color, scarlet, with a brightening dash of orange.

Victory-Exceptionally satisfactory and useful as a cut flower. owing to its great stability, its nice long stems, and the prodigality of its bloom. Color, brilliant scarlet.

White Enchantress-One of the best whites yet produced, of pure quality, large size and immence productinn. Shape and habit closely follow the parent, Enchantress.

White Perfection-All that its name implies. Bloom is abundant, of large size, and immaculate whiteness.

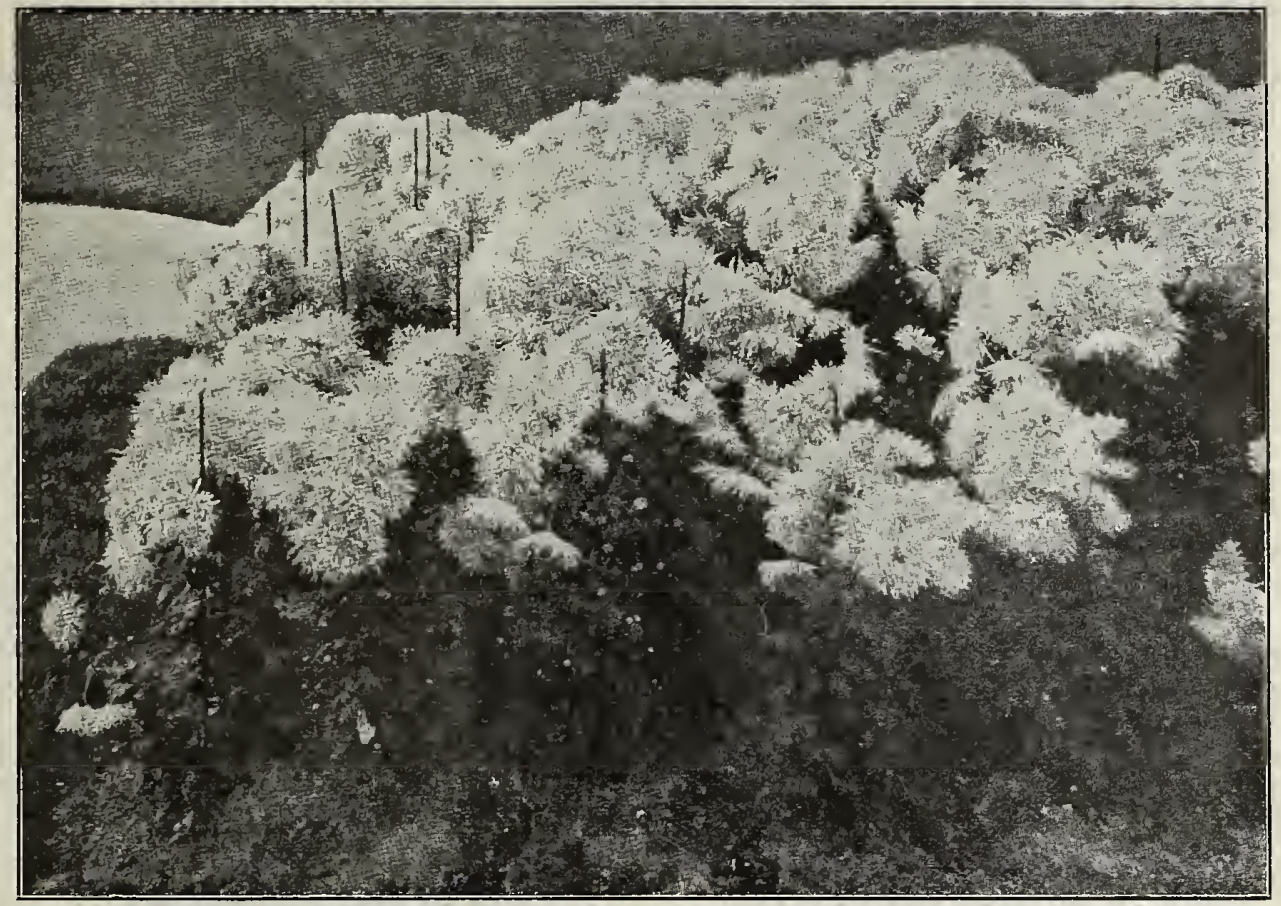

\section{Chrysanthemums}

We grow ten of the best varieties of yellow, white and pink "Mums". Plant in open ground in May. 10 cents each; $\$ 1.00$ per dozen. Large plants in September and October by express 50 cents each.

\section{Coleus}

There is nothing in the line of bedding plants that can ever take the place of Coleus. Used in solid clumps or as edging to Canna beds, etc. We grow 11 of the best colored varieties; plant as soon as danger of frost is over. 5 cents each; 50 ccnts per. dozen.

\section{Ficus Elastica (India Rubber Tree)}

Nothing hetter for table or house decoration. Its dark green, shiny foliage is always handsome, and its constitution is such that it is able to stand the excessive heat and dry ntss of the ordinary dwelling house without injury. 35 cents; large plants by express, 50 and 75 cents each.

\section{Dahlias}

No garden is complete without a show of these brillint and stately Autumn flowers, and nothing gives greater return for so little money and care. We have a fineassortment of the best varieties of yellow, pink, red, white and maroon. Bulbs are too heavy to send by mall; express, 20 cents each; 6 for $\$ 1.00$.

\section{Fuchsias}

For win low pot plants or for partially shady spots in the garden, these plants, with their gracefully drooping flowers, are held in high favor. We grow 6 varieties, 15 cents each 4 for 50 cents. 


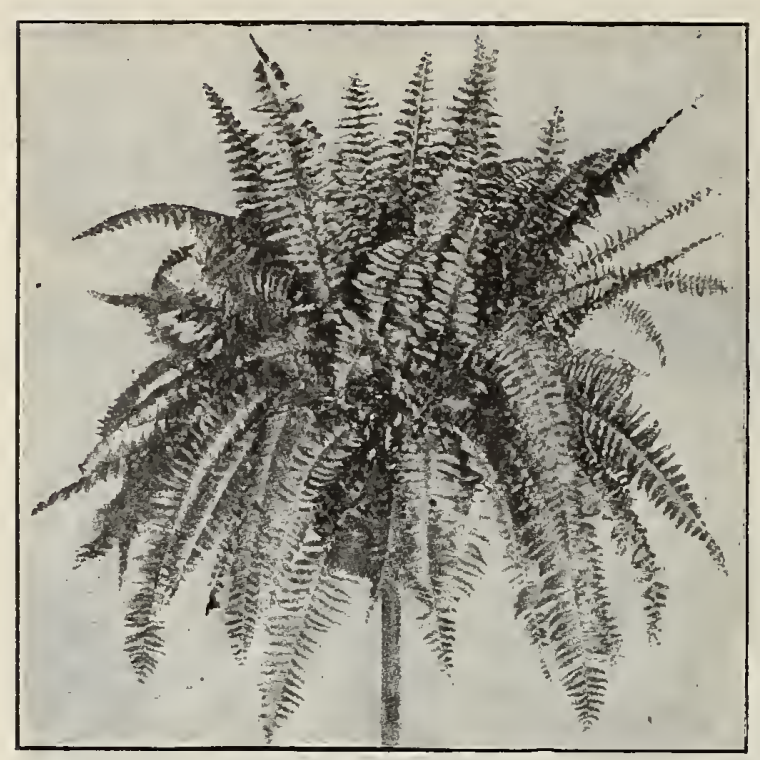

Boston Hern

\section{Ferns}

There are no more attractive plants, or plants that are more generally useful than Ferns. Their great beauty and diversity, together with their adaptability in arrangement with all kinds of flowering and ornamental plants make them an almost indispensable adjunct to the home and conservatory. Not requiring stronglight they can be used to advantage in places the sun does not reach. Largely used also for cutting, as a few sprays serve to lighten and give an artistic finish to any bouquet or design. We list the most desirable varieties.

Whitman Fern-Similar to the Boston Fern only that the fronds are shorter and fringed. Prices same as Boston.

Boston-Sometimes called "Fountain Fern", on account of its gracefully drooping habit. Fully matured fronds often attain a length of four feet. $10 \mathrm{c}$ each.

\section{LARGE PLANTS BY EXPRESS}

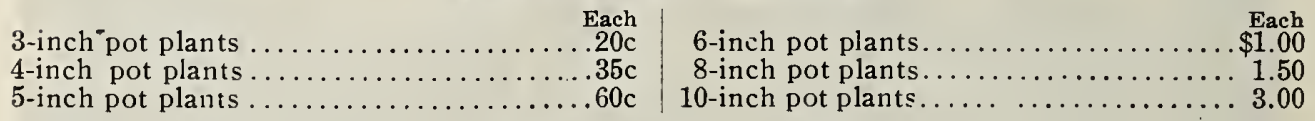

\section{Geraniums}

Throughout all the fluctuations of taste and requirements which popularize one class of plants and then another, Geraniums have held and still retain a foremost place in popular estimation, which seems impregnable. As pot plants, they are always serviceable and useful; while for summer bedding purposes they are almost indispensable.

\section{DOUBLE FOWERING VARIETIES}

Unless otherwise noted, price $10 \mathrm{c}$ each; $\$ 1.00$ per dozen postpaid. Geraniums in 4 inch pots for bedding out in May and June per dozen $\$ 1.75$; per hundred $\$ 12.00$ by express at customer's expense.

Beauty Poitevine-One of the semidoubles and has no equal in its color; trusses immense and of a fine shape; color beautiful rosy salmon, nicely shaded and tinted. Foliage thick, leathery; strong habit of growth.

Jean Viaud - A wonderiul fine Geranium for winter or summer blooming. Flowers semi-double, of largest size, borne on immense stalks. Color fresh bright rose pink, the upper petals marked with white blotches, adding greatly to freshness of coloring; grand everbloomer, fine form.

La Favorite-Trusses very la r ge ; purest snow white, even when grown in the open ground.

Mrs. E. G. Hill-Large single flowers; bright salmon, with a light shading at center.

S. A. Nutt-Rich crimson. The old standby.

Alphonse Ricard-Semi-double, dwarf and branching, bright orange red.

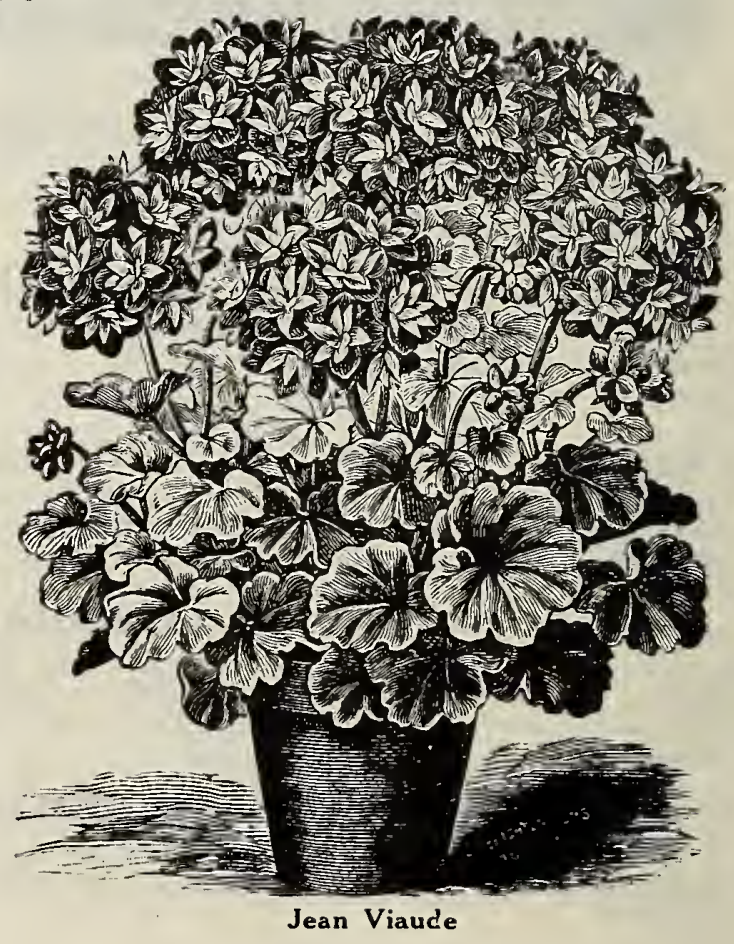


Mad. Salleroi-A very compact variety of Silver Geranium; very fine for massing or bordering, thrifty, healthy grower, rarely reaching a height of more than six inches: leaves very small, of peculiar clear green, edged with pure white.

\section{Gladiolus}

One of the most attractive of summer flowering bulbs. Very ornamental for the lawn. To obtain a succession of bloom there should be several plantings made at intervals of a week. Set bulbs 6 to 9 inches apart and about 4 inches deep. If the soil is poor see that it is carefully enriched. The flowers are excellent for cutting and last a week in water, the buds opening well. The bulbs should be taken up in the fall before heavy freezing weather sets in and allowed to dry off in the sun. Cut off the stem close to the bulb, put in paper bags and place where they will not freeze. A cold dry atmosphere is best. We have a fine collection of the large flowering sorts. Dry bulbs, 5 cents each. $\$ 3.50$ per 100 .

\section{Heliotropes}

Florence Nightingale - Bright lavender, still one of the best and most popular.

Snow Wreath-Blooms in large trusses of fragrant white flowers. An excellent sort. Unless noted, 10 cents each; 6 for 50 cents.

\section{Oleanders}

An old favorite, largely used for house, porch or lawn decorations. Easily wintered in a cellar where it does not freeze.

Pink and White-Double flowered. 20 cents each.

\section{Hydrangeas}

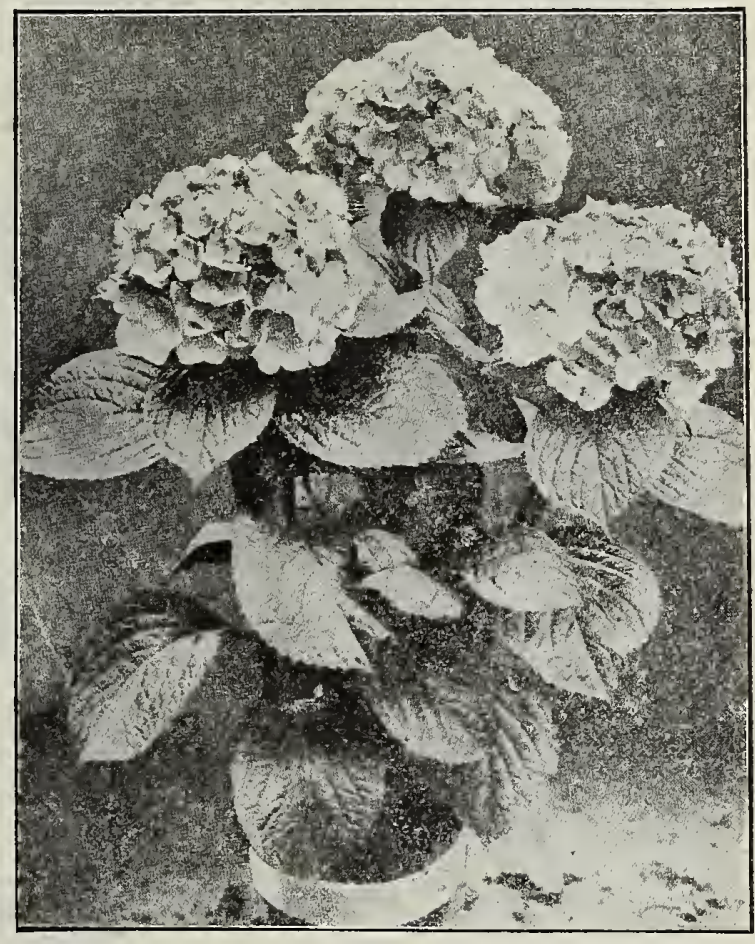

Otaska

Otaska-A Japanese variety used extensively for Easter decorations. Flowers large, bright pink, tinted with blue. 10 cents. 4 -inch pot plants, 25 cents each.

\section{Lantanas}

The Lantanas make fine bedding and basket plants and are increasing in favor. They bloom continuously from spring until cut down by frost.

Weeping Lantanas-A most excellent plant for basket and vases. It is very effective on account of its bright colored bloom; flowers delicate rosy lilac, borne freely all over the plant. 10 cents each.

Aurora-Pink and yellow center. 10 cents each.

Emily Bayard-Deep orange crimson, with yellow center. 10 cents each.

Favori-Light buff, changing to white. 10 cents each.

Harkett's Perfection-Golden variegated foliage; flowers, yellow and pink. 10 cents each; dozen $\$ 1.00$.

\section{Petunias}

Very easily grown and truly satisfactory wherever placed.

Purity-A remarkable fine, double Tower. Plant is strong and stocky; flowers are very large and very double, also finely fringed. Color, pure white.

Double Pink. Double Crimson-10 cents each; 8 for 50 cents. Primula (Primrose)

Nothing is more satisfactory for a winter flowering plant.

Forbesi-(Baby Primrose)-The smallest flowered of all Primroses. Blooms nearly all the year round; has good sized trusses of dainty little rosy-lilac blossoms. 15 cents each; $\$ 1.25$ per dozen postpaid. 
Chinensis-(Chinese Primrose)-Fine winter bloomer. Crimson and white. Free flowering, blossoms large. 15 cents each; $\$ 1.25$ per dozen, postpaid.

Obconica Grandiflora-Large flowered and extremely prolific, mixed, in shades of red, pink and white. 10 cents each; 3 for 25 cents; 75 cents per dozen.

\section{Salvia}

Splendens-A remarkably fine bedding plant. The latter part of summer and early fall it is covered with great masses of dazzling scarlet flowers, which remain in bloom until cut down by frost. 10 cents each; 3 for 25 cents.

\section{Smilax}

A very graceful climber, possessing the rare qualities of delicate and dense foliage and vining habit, admirably adapting it to climbing or drooping. It is fine as a parlor or window plant. 10 cents each.

\section{Moon Vine}

One of the most rapid growing vines, often 40 feet in a single season, fine for trellises or screens, large white bloom. 10 cents each.

\section{Vinca Major Variegata}

More of this used for baskets and vases than there is of any other two basket plants. Beautifully variegated green and white foliage, and strong trailing habit of growth.

\section{Violets}

Of all delightful perfumes, that of the Sweet Violet is the most delicate and pleasing. If grown in the house for winter flowers, they should be kept at a low temperature; they will not bloom freely where it is too warm. If left in the open ground during the winter, protect with a covering of leaves.

California-The plant is a robust grower with dense, heavy froliage, entirely free from the disease that is so destructive to other sorts. Flowers single, intensely fragrant. Color, a clear, violet purple that does not fade. The flowers are very large and borne on stems ten to twelve inches long, giving them unusual value for cut flowers.

Princess of Wales-Broad Pansy-like flowers of a beautiful violet purple shade, with lighter center. A vigorous growing plant with clean healthy foliage and stiff long stems. One of the most beautiful and free flowering Violets.

Marie Louise-The variety that is so largely grown to supply the cut flower trade. Color, rich purple, flowers fragrant; double. $10 \mathrm{c}$ each; three for $25 \mathrm{c}$; $\$ 1.00$ per dozen.

\section{Hoyia}

Or Wax Plant-A fine climber, will grow best without sunlight; thick shiny leaves and large sweet scented waxy flowers. 25 cents each.

\section{Tuberoses}

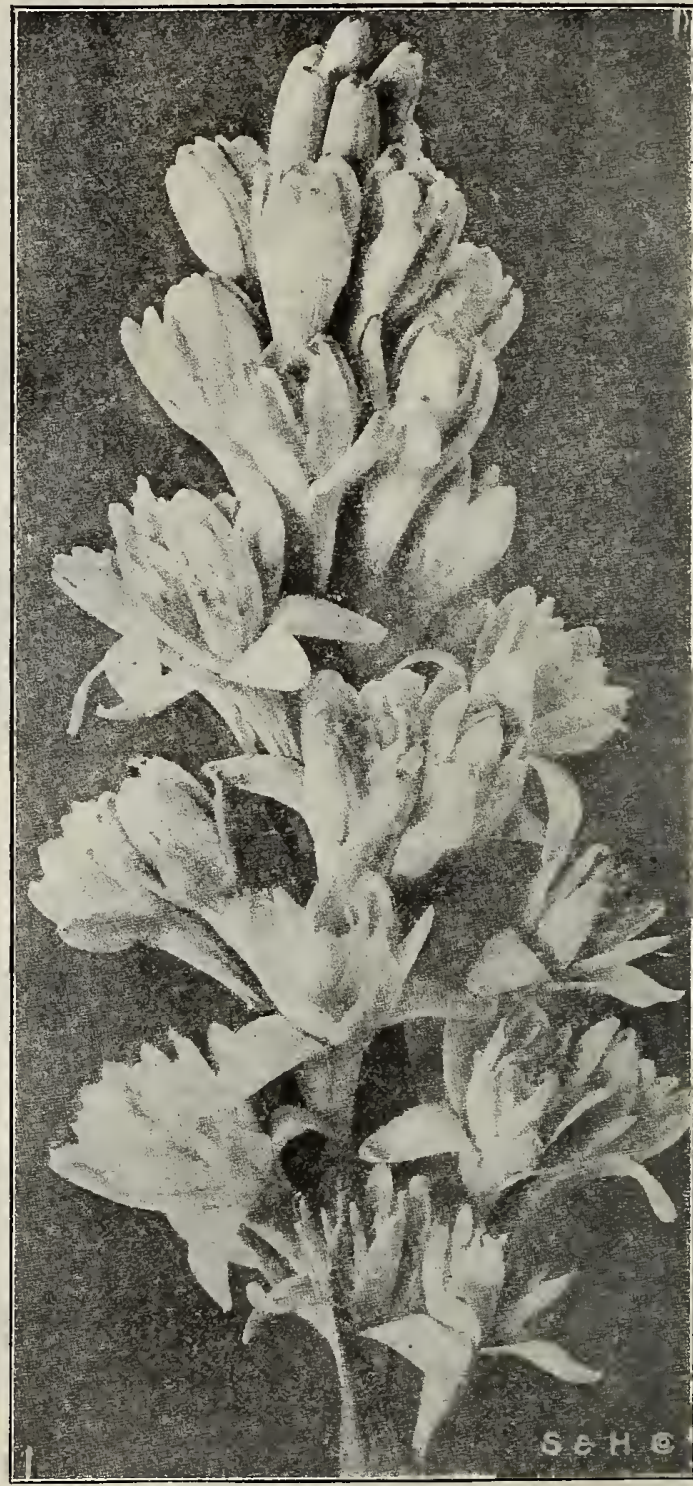

Excelsior Pearl Tuberose

Excelsior Pearl-Double white, dwarf, selduin over 18 inches high. 5 cents each; 6 for $\Delta 5$ cents.

Fall Double-Grows very large, often 5 feet; pure white double, blooms late in the fall. 5 cents each; 6 for 25 cents. 


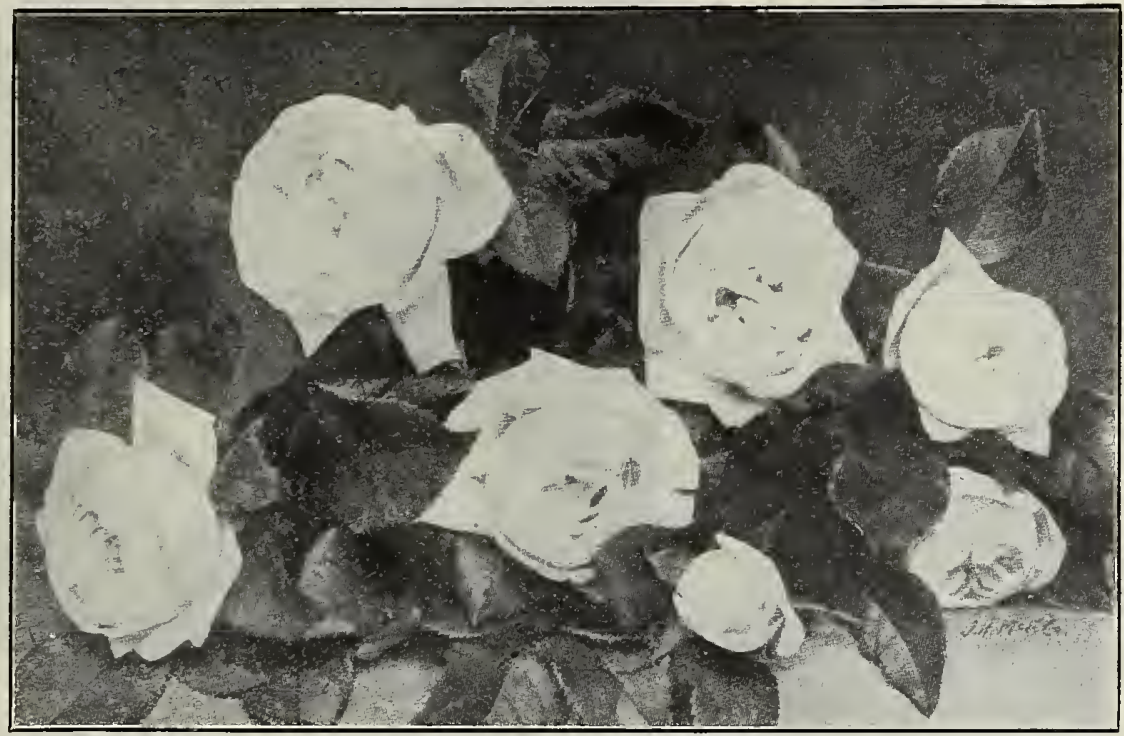

Margaget Dickson Rose

\section{Roses}

Roses thrive best in a good, well-drained clay soil where they can have plenty of sunlight. Make the ground rich with well-rotted manure, and in spring severely prune all varieties except climbers and Persian Yellow. Cover in the fall with some coarse dry material.

15 cents each; 8 for $\$ 1.00$. These prices are for small plants, from $2 \frac{1}{2}$ inch pots.

\section{Hardy Roses}

Prairie Queen-Rosy-red, frequently with white stripes, medium to large size, double, foliage large; five leaflets, quite deepty serrated.

Crimson Rambler-Flowers are a bright, cheerful shade of crimson, and the great size of the clusters make it especially attractive. The flowers are double, about the size of a cherry blossom. A beautiful sight for about a month. A rapid grower.

General Jacqueminot-Very fragrant; not very full, but large and effective. One of our best garden Roses.

Margaret Dickson-A very free grower: foliage large and dark. Flower white, with pale fiesh center; petals are thick and bell-shaped, quite fragrant, a fine sort.

Paul Neyron-The largest variety in cultivation. Deep rose color, very full and double, finely scented, good foliage and free bloomer.

American Beauty-Large globular, deep pink, shaded with carmine; delicious fragrance; a most desirable variety or forcing.

Uirich Brunner-Brilliant cherry red, a very effective color; flowers of fine form and finish carry well upon the plant. Petals of great substance; plant vigorous, hardy, and, resists mildew.

\section{House or Tea Roses}

Bridesmaid-The most popular pink Tea Rose. Fine for cut flowers; bright pink, free flowering

Perle des Jardins-Beautiful clear yellow, flower large and fine form.

Killarney-Bright pink wtth lemon at base of petals. Large, long, pointed buds of great beauty and sweetly fragrant. A charming variety.

Richmond Beauty-Fine shape and brightly colored in pure dark scarlet crimson.

The Bride - The standard pure white rose; flower fine, large size, fragrant.

Baby Rambler-This new Rose is a dwarf bush form of the Crimson Rambler, and is an ever-bloomer. May be used as a pot-plant or garden Rose, blooming continuously in either place. The blossom is the same color and form as the Crimson Rambler, the clusters having from twenty to forty blossoms at a time. Is certainly a great acquisition.

New White Baby Rambler-A valuable addition, producing double, pure white flowers with the fragrance of Hyacinth. Of free compact growth-attaining a heiglit of 20 inches. 


\section{Peonies}

That Herbaceous Peonies are as fine and effective in their way as Rhododendrons or Roses is now being generally recognized. They are hardier and more easily eultivated than either of their rivals, and are being used in the same way for bold display of color. Their flowers are very lasting; some of them are finely finished and exquisitely colored. Plant in deep, rich well-prepared soil, cuvering the buds but an inch or two. Do not expect too much of them the first year. They are a little slow in establishing themselves.

Peonies are too Jarge to be sent by mail. We can furnish red, white and pink, strong plants, 20 cents each. 6 for $\$ 1.00$.

Delicatissima-This b e a u $\mathrm{t}$ if ul flower should be in every garden. Very large; delicate, clear pink, lighter in the center; very fragrant; free bloomer; exceptionally pretty in the bud; a quality flower in every sense. It is unexcelled as a cut flower. 35 cents each; $\$ 3.50$ per dozen.

Edulis Superba-(Lemon)-Very large, bright rose flower; a beautiful early variety. 30 cents each.

Pottsij-Dark crimson; yellow stamens showing through the flower, early. 30 cents each.

Nigra-(Terry) - Full double flower; the darkest crimson of any; long, willowy stems; blooms late. 30 cents each.

Modest Guerin-Brilliant carmine-rose, with a high and stiff center full of rosy-pink petals.

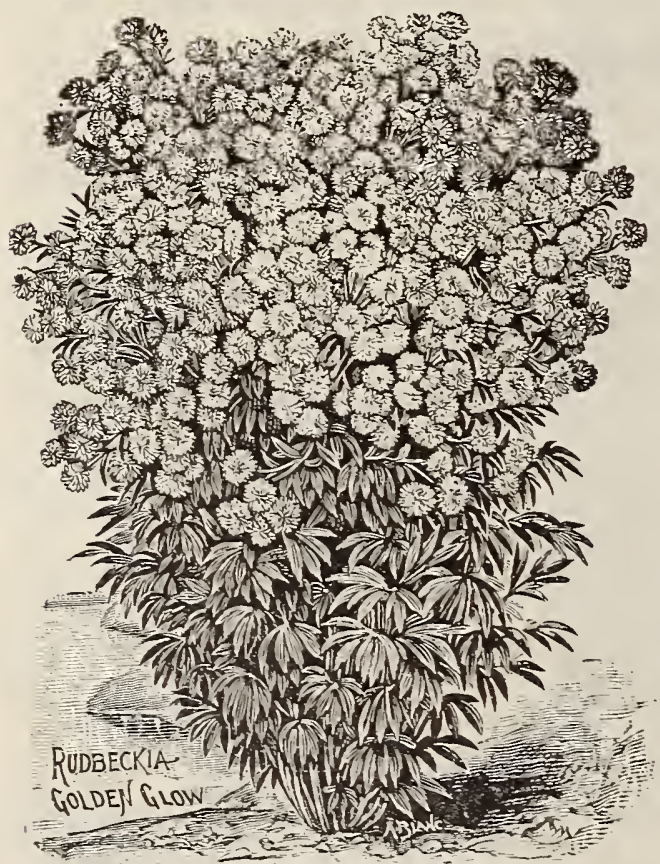

Queen Victoria - The broad guard petals are a pretty bluish white; center slightly edged pink. Large. 30 cents.

Rudbeckia "Golden Glow"The most prolific and satisfactory hardy perennial of all yellow flowering sorts. Grows 5 to 7 jeet and blooms irom early summer until frost. Flowers are produced on long stems in enormous quantities, and resemble golden-yellow Cactus Dahlias. 10 cents each; 75 cents per dozen.

Yucca Filamentosa - (. Adams Needle or Spanish Bayonet)-A stately foliage and flowering plant equally imposing in solitary or group plantings, always conspicuous. The broad sword-like foliage is evergreen; while midsummer shows great erect branching stems bearing a showy display of pendant, creamy-white bells. 10 cents each: $\$ 100$ per dozen. Strong 3-year by express, 25 cents each; $\$ 2.50$ per dozen.

\section{Feverfew}

A fine house plant with bright tolinge and double pure white flowers. 10 cents each: 3 for 25 cents. 


\section{Dicentra (Bleeding Heart)}

D. Spectabilis-A hardy perennial with heart-shaped, rose-colored flowers in drooping spikes. One of the best border plants. perfectly hardy and easily cultivated; 2 feet high. Flowers in Apr or May, 25 cents each.

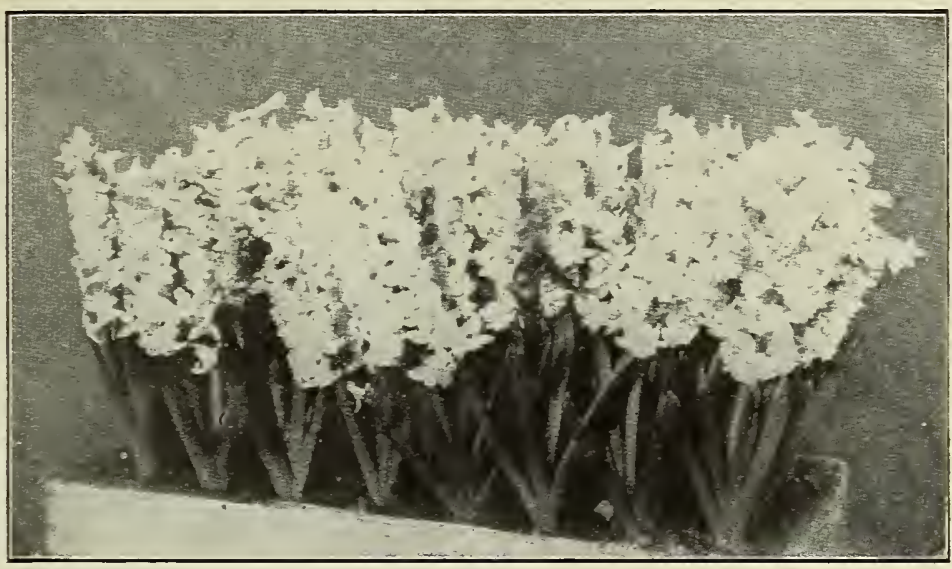

Hyacinıhs

\section{Bulbs for Fall}

Hyacinths-Red, white and blue. 10 cents each; 3 for 25 cents.

Crocuses-Assorted colors, 5 cents each; 6 for 25 cents.

Narcissus-Pure white. 5 cents each, 6 for 25 cents.

Tulips-Assorted colors, single and double. 5 cents each; 25 cents per dozen.

\section{Bulbs for Spring}

L. Auratum-Gold-banded Lily of Japan-Flowers very large, delicate ivory white, thickly dotted with rich chocolate spots. A bright golden band runs through the center of each petal. The finest of all Lillies. 20 cents each; 3 for 50 cents.

L. Harrisii-(Bermuda Easter Lily-Flowers large, trumpet-shaped, pure waxen white, gracefully formed and delightfully fragrant. The ease with which it can be forced into flower in winter has made it wonderfully popular, for church decoration at Easter. $20 \mathrm{c} \mathrm{each} ; 3$ for $50 \mathrm{c}$.

\section{Vegetable Plants Sweet Potatoes}

White SurprIse and Yellow Jersey-Plants are usually ready for shipment May 10. By Mail, prepaid . Per 1 no Per 1000

\section{Tomatoes \\ Earlyanna, Champion and Trophy}

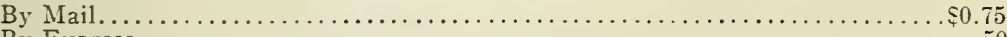

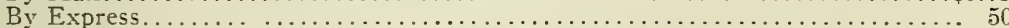

Cabbage

\section{Early Wakefield and Surehead}

By Mail. . . . . . . . . . . . . . . . . . . . . . . . . . . . . . $\$ 0$

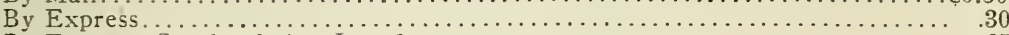

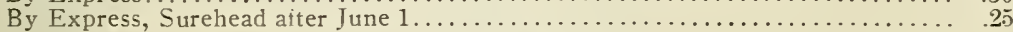

\section{Pepper}

Giant Sweet, Mango and Cayenne

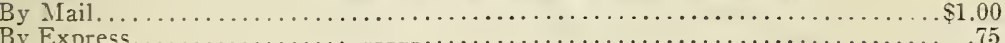




\section{Index}

Asparagus Fern.................. 39

Ageratum....................... 39

Apples....................... 6

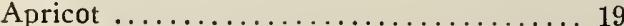

Asparagus...................... 26

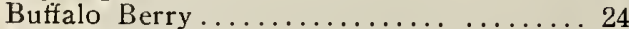

Begonia....................... 39

Bleeding Heart................... 46

Crab Apple ..................... 11

Cherry...................... 16

Compass Cherry ....................... 18

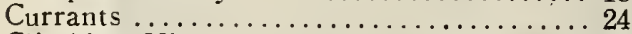

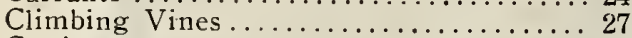

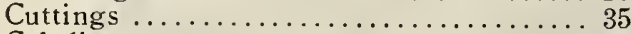

Caladium........................... 39

Cala ............................. 40

Camua ............................... 40

Carnations .......................... 40

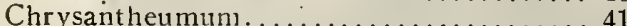

Colens ........................... 41

Crocus ............................... 47

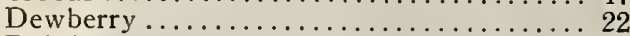

Dahlia .......................... 41

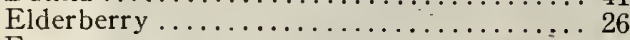

Fvergreens...................... 34

Forest-Seedlings ..................... 36

Fusias...................... 4

Ferns ....................... 42

Feverfew.......................... 46

Grapes ........................ 19

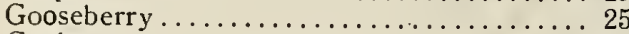

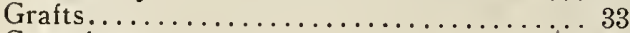

Geranium ........................... 42

Gladiolus....................... 43

Golden Glow ..........................

Horse Radislı........................ 26

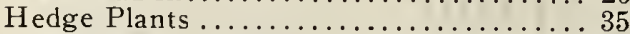

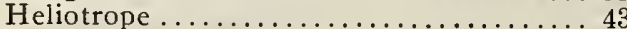

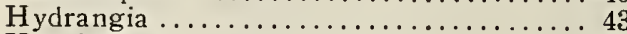

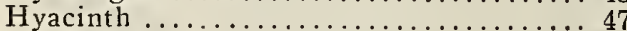

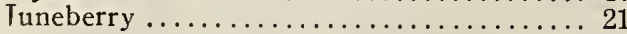

Loganberry ..................... 22

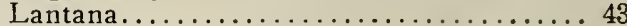

Lillies ........................ 47

Mulberry...................... 33

Nectarines ...................... 13

Nut trees...................... 32

Norway Poplar ................... 33

Narcissus ..................... 47

Ornainental Shrubs ............... 27

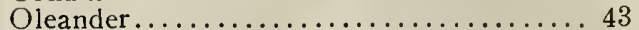

Pear ............................. 12

Peach.......................... 13

Plum ............................. 15

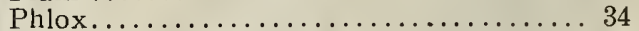

Petunia ...................... 43

Primrose............................. 43

Peonias....................... 46

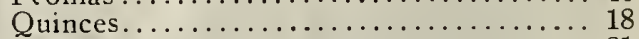

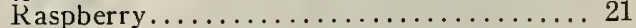

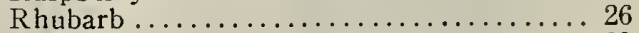

Roses........................ 4529

Rubber Tree.................... 41

Strawberry Raspberry ............... 22

Strawberry . ...................... 25

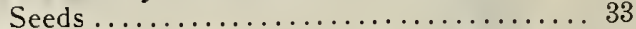

Shade Trees..................... 35

Sweet Corn ...................... 37

Salvia....................... 43

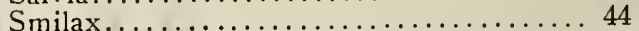

Tree Protectors.................... 36

Tube Roses ....................... 44

Tulips...................... 47

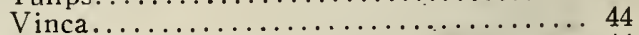

Violets....................... 44

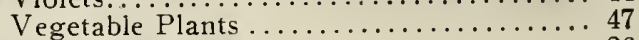

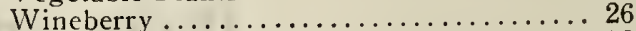

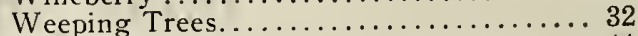

Wax Plant..................... 44

Yucca....................... 46

Cut This Out and Return With Your Order

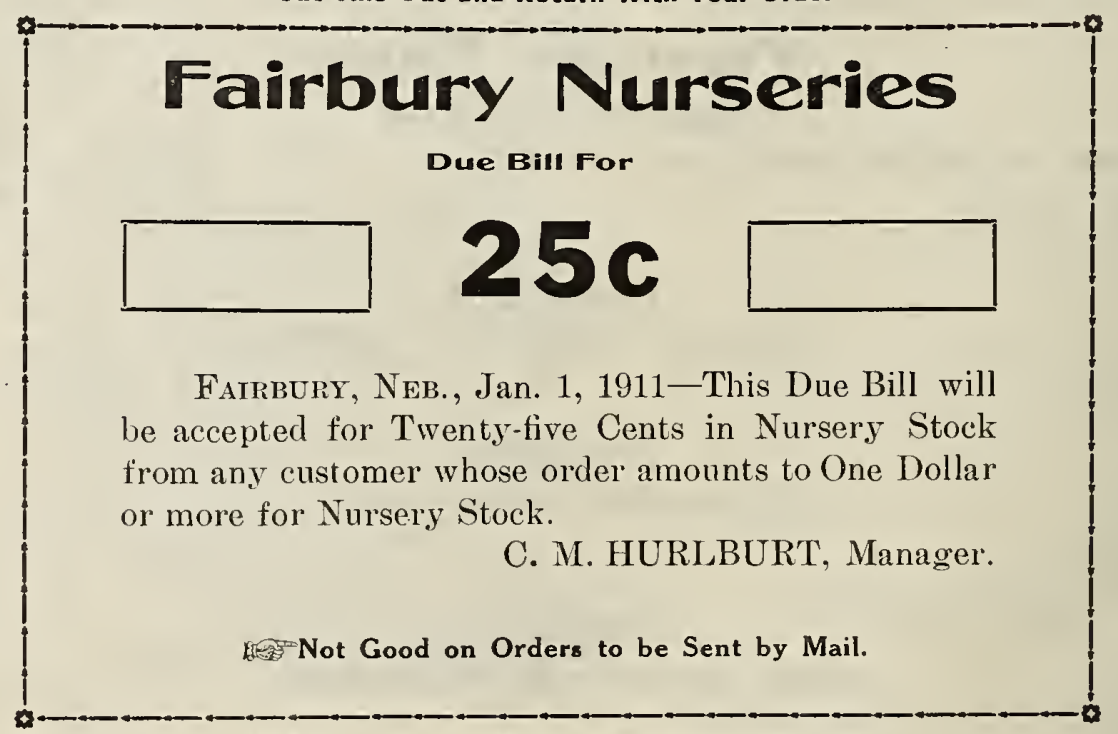

Address C. M. HURLBURT, Manager, Fairbury, Neb. 


\section{If arnutlats}

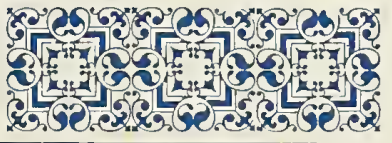

BORDEAUX MIXTURE. Copper sulphate, 6 pounds; quicklime, 4 pounds; water, 40 to 50 galions. Dissolve the copper sulphate by putting it in a bag of coarse cloth and hanging this in a vessel holding at least 4 gallons, so that it is just covered by the water. Use an earthen or wooden vessel. Slake the lime in an equal amount of water. Then mix the two and add enough water to make 40 gallons. The liquid is then ready for immediate use but will keep indefinitely. If the mixture is to be used on peach foliage it is advisable to add an extra pound of lime to the above formula. When applied to such plants as carnations or cabbages it will adhere better if about a pound of hard soap be dissolved in hot water and added to the mixture. Use for rots, molds, mildews and all fungous diseases.

COPPER SULPHATE SOLUTION." Copper sulphate, 1 pound; water, 15 gallons. Dissolve the copper sulphate in the water, when it is ready for use. This should never be applied to foliage, but must be used before the buds break. For peaches and nectarines use 25 gallons of water. Use for fungous diseases.

KEROSENE EMULSION. Hard so a p, $\frac{1}{2}$ pound; boiling water, 1 gallon; kerosene, 2 gallons. Dissolve the soap in the water, add the kerosene, and churn with a pump for 5 to 10 minutes. Dilute 10 to 25 times before applying. Use strong emulsion for all scale insects, for insects which suck, as plant-lice, mealy bugs, red spider, thrips, bark-lice, or scale. Cabbage worms, currant worms, and all insects which have soft bodies, can be destroyed with this emulsion.

PARIS GREEN. Paris green, 1 pound ; water, 200 gallons. If this mixture is to be used upon peach trees, 1 pound of quicklime should be added. Repeated applications will injure most foliage, unless lime is added. Paris green and Bordeaux mixture can be applied together with perfect safety. Use at the rate of 4 ounces of the arsenites to 50 gallons of the mixture. The action of neither is weakened, and the Paris green loses all caustic properties. Use for insects which chew.
HELLEBORE. Fresh white hellebore, 1 ounce; water, 3 gallons. Apply when thoroughly mixed. This poison is not so energetic as the arsenites, and may be used a short time before the sprayed portions mature. Use for insects which chew. Can also be used dry by dusting on plants.

LONDON PURPLE. This is used in the same proportion as Paris green, but as it is more caustic it should be applied with two or three times its weight of lime, or with Bordeaux mixture. The composition of London purple is exceedingly variable, and unless good reasons exist for supposing that it contains as much arsenic as Paris green, use the latter poison. Do not use London purple on peach or plum trees unless considerable lime is added. Use for insects which chew.

LIME, SULPHUR AND SALT. Stone lime, 15 to 30 pounds; flowers of sulphur, 15 pounds; salt, 15 pounds; water; 50 gallons. Slake the lime in a small quantity of hot water, gradually adding and thoroughly stirring in the sulphur. Dilute the mixture with twelve gallons of water and boil in an iron kettle or cook by steam in a covered tank or barrel for one and one-half hours. Then add salt, continuing the boiling for one-half hour more. Fill vessel up with water to the required fifty gallons. Strain, wash through a fine mesh strainer and apply hot. In using an iron kettle, keep the mixture vigorously boiling and thoroughly stirred to prevent caking and burning of materials. Wash cooked by steam is more easily prepared and better made. Apply wash just as the buds begin to swell in the spring. Cover all parts of the tree with a heavy coat of the wash. The wash seems best adapted to orchardists who have not yet learned to use petroleum with safety or are afraid that their trees are beginning to show injury from the oil or will not stand many more applications of it. It is especially recommended for the treatment of peach trees. It is believed that the substitution of one and one-fourth pounds of blue vitriol dissolved in hot water.for the salt results in a quicker acting wash. This formula is known as the Oregon Wash. Use for scale and fungous diseases.

Any of the Agricultural Experiment Stations will furnish bulletins so arranged that the grower may see at a glance what to apply, when and how to make the applications. 
